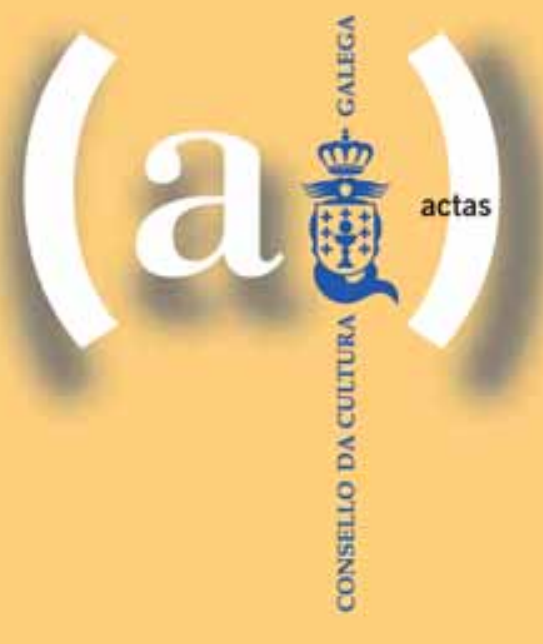

RAMÓN MÁIZ

TIFFANY SHELLAM

EDITORS

\title{
Rosendo Salvado and the Australian Aboriginal World
}

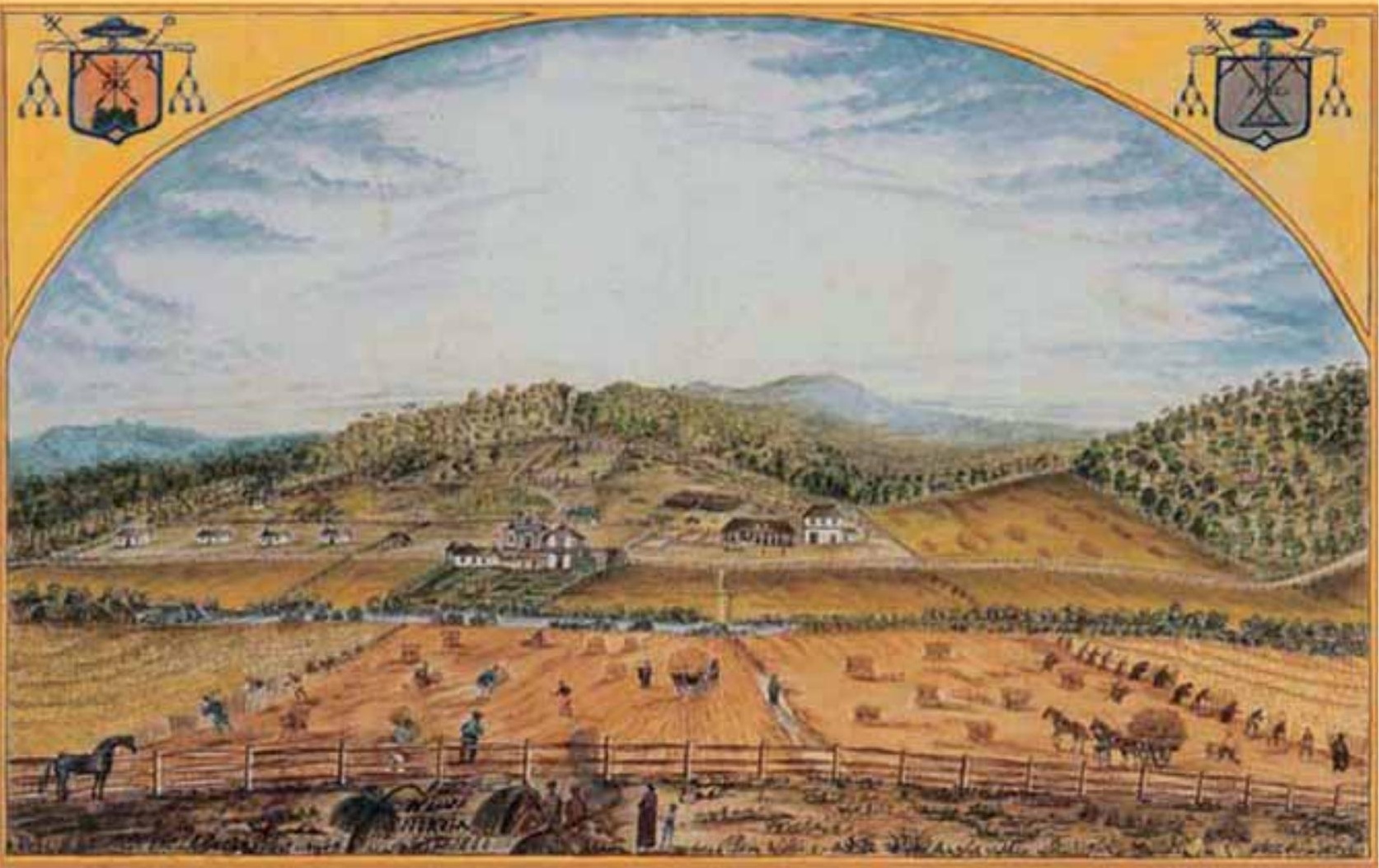



Rosendo Salvado and the Australian Aboriginal World 


\section{Published by}

(c) CONSELLO DA CULTURA GALEGA, 2016

Pazo de Raxoi $\cdot 2^{\circ}$ andar $\cdot$ Praza do Obradoiro

$15705 \cdot$ Santiago de Compostela

T $981957202 \cdot$ F 981957205

corre0@consellodacultura.gal

www.consellodacultura.gal

\section{Translation and linguistic review}

Cristina Río López

Begoña Tajes Marcote

\section{Cover image}

Vista de Nova Nursia, 1860 / View of New Norcia, 1860

\section{Layout}

Lugami Artes Gráficas

Doi:10.17075/rsmaa.2016.en 
RAMÓN MÁIZ

TIFFANY SHELLAM

EDITORS

\section{Rosendo Salvado and the Australian Aboriginal World}


Presentation 


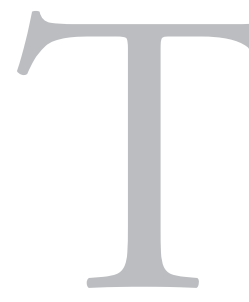

he Council for Galician Culture has been promoting different activities around the figure of Rosendo Salvado for more than a decade. Our aim is to rescue the immense work of this illustrious Galician man who settled in Australia and to shed some light on a man of his time, who was against his time but also well above of the time when he lived. An individual who carried out pioneering work that established a dialogue with a particular place in faraway Oceania in which he tried to find a synthesis between the Western civilisation he carried with him and a different, allegedly inferior Aboriginal culture he found upon his arrival in Australia.

Rosendo Salvado was not, however, very well-known in Galicia. But from 1999 his figure was gradually integrated into Galician culture thanks to several exhibitions, conferences and publications that showed the special dimensions of his personality, marked by cultural pluralism that was innovative for his day. $\mathrm{He}$ demonstrated a spirit of understanding of different cultures, of the relationships between the Western world and the Aboriginal world, which he discovered from 1845 on, after his first trip to New Norcia. The exhibition organised then travelled to Australia too, which helped us make the links between the two homelands of the illustrious Tui native even tighter.

Salvado erected in Australia a Benedictine community that was built on an atypical civilisatory plan, one that began with something as close to us as names. Salvado encouraged Aborigines to take Christian baptismal names, while keeping their Indigenous surnames, as initial forms of address. But he also demonstrated a rare interest in education, against the incomprehension Rome repeatedly showed. This strategy of Salvado's resulted in the creation of a 
number of schools and, above all, in the teaching of trades to Aborigines: 'Properly instructed the aboriginal acquires a just idea of both the value of money and property,' as he wrote in one of his many manuscripts. In the particular way in which he saw colonialism, he set up a pioneering rural bank that would grant credit for Aborigines' farms; he also paid them wages in exchange for their work. To Salvado, to have Aboriginal men working without recompense would make them feel the burden of civilisation without its advantages. And these were some of the recipes for his success.

In the following pages, readers will be able to find out about an individual concerned about the rights of Aborigines, on whom he left a deep mark. But they will also find a description of the vast legacy that lies in the New Norcia Community in the shape of maps, diaries, letters, account books, employment records and others - private materials that reveal a great deal about his sensitivity to draw a community to a place where nobody had before. The fact that he was a Galician, of Celtic origin, with pre-Christian traditions that live on in a world of spirits and superstitions and are closely linked to the land, may have helped him relate so well to a highly spiritual community that has preserved his memory until this day.

The most substantial part of Rosendo Salvado's legacy has been compiled and studied in this book. Its contents are the result of the painstaking work of professors Ramón Máiz and Tiffany Shellam, who coordinated a congress that brought a number of outstanding individuals from the Antipodes, such as Susan Ballyn or Peter Hocking, or Giulio Cipollone, Antonio Linage Conde or María Jesús Lorenzo Modia from places closer to home. Thanks to these studies and the exhibition that toured Galicia in 2014, the figure of Rosendo Salvado has much more pluralistic and complex traits today than that stereotyped image according to which his importance boiled down to his alleged role in the dissemination of eucalyptus in Galicia. Also in this case, we should draw the best guidelines for our times from the biography of Salvado himself: tolerance and understanding of others, without renouncing one's own identity. 
The activities focused on Rosendo Salvado that the Council for Galician Culture promoted in 2014 could be carried out thanks to the efforts of different members of the Plenary Board (Ramón Máiz, Francisco Díaz-Fierros, Segundo Pérez) and the staff of our institution, as well as external support from very different bodies: the Bishopric of Tui, the Archbishopric of Santiago de Compostela, the Universidade de Santiago de Compostela and, in particular, the Australian Embassy in Spain, whose incumbent at that time was Ms Jane Hardy. To all these people and institutions, many thanks for their help. 



\section{Table of contents}




\section{PRESENTATION}

13 Rosendo Salvado and the Aboriginal World: reading aboriginal autonomy in the light of a pioneer's legacy

Ramón Máiz and Tiffany Shellam

25 Searching for Rosendo Salvado in 1978

Doireann MacDermott

31 Salvado: a man of and before his time

Ronald M. Berndt

43 Recovering the memory of Rosendo Salvado in Galicia

Francisco Díaz-Fierros Viqueira

51 Rosendo Salvado: a Benedictine odyssey in the Antipodes

Antonio Linage Conde

81 Salvado's archives: a unique legacy

Peter Hocking

97 Power in conflict with the essence of peoples

Susan Ballyn

111 Bishop Rosendo Salvado's vision of Aboriginal mission work in the Victoria Plains of the colony of Western Australia

Anna Haebich

135 Salvado and the Indigenous Australian: of the same human race. Equality and dignity ante litteram

Giulio Cipollone

155 'On my ground': Indigenous farmers at New Norcia 1860s-1900s

Tiffany Shellam

179 Civilistion and alturein Rosendo Salvado

Ramón Máiz

203 Literary and cultural voyages between Galicia and Australia

María Jesús Lorenzo Modia

223 Rosendo Salvado and us Aborigines

Paul Willaway 
ROSENDO SALVADO AND

THE ABORIGINAL WORLD:

READING ABORIGINAL

AUTONOMY IN THE LIGHT

OF A PIONEER'S LEGACY

Ramón Máiz

University of Santiago de Compostela

Tiffany Shellam

Deakin University

Doi: 10.17075/rsmaa.2016.en.001 

The commemoration of the $200^{\text {th }}$ anniversary of Rosendo Salvado's birth (Tui, 1 March 1814) is a timely occasion to delve into a key aspect of his life and work, one that is, in fact, the keystone of all of his extraordinary career: his indigenist thinking and practice. His commitment to the Aboriginal world involved the radical rejection of the brutal ethnocentric, racist approach that was customary in the time of the British Empire, i.e., the approach whereby the Aborigines were considered miserable 'soulless' bodies, the remnants of a 'doomed race' (the doomed race theory), or even beings belonging to the same species 'as orangutans'.

The emphasis laid on the extraordinary dimension of his missionary efforts, or a misguided focus on his legendary importation of eucalyptus to Galicia, have concealed the very core of his life project - his formidable efforts to promote the personal and political autonomy of Australian Aborigines as human beings with rights and, therefore, with a civil future. Salvado carried out this task displaying, at all times, an openly belligerent attitude against the discourses and practices that both Protestantism and Catholicism had established, and his ways were far removed from those of 'evangelists of empire'. One only needs to compare his open, unprejudiced attitude of dialogue with the strongly traditionalist, narrowminded approach of the man who had been his partner in the order and in misfortune in Australian lands from their time in the Monastery of San Martiño Pinario in Compostela, José Serra. In Salvado's own words, 'In Australia, the Europeans absorb all of missionaries' minds, all of their time, all of their means, and the poor savages remain entirely abandoned and forgotten [...]. Everything, absolutely everything is done for the Europeans; nothing, absolutely nothing for the savages' (Salvado, 1883: 432).

The recent publication of the Galician edition of Salvado's memoirs, Memorias históricas sobre a Australia e particularmente sobre a Misión Beneditina de Nova Nursia e os usos e costumes dos australianos (Salvado, 2014), will perhaps lead us Galicians to adopt a more suitable approach and pay closer attention to 
his exceptional career as we still wait for fresh discoveries resulting from the ongoing transcription of his Diaries, handwritten by the men in charge of the New Norcia Archives.

It is particularly striking to see how Salvado himself was lucidly aware that, drawing on his exhausting experiences and his daily reflexion in the inclement environment of the bush, he was developing some ideas and principles of his own, which were innovative at that time, ultimately heterodox, always against the tide of the dominant vision. These were the foundations of the original 'Salvado method', the 'New Norcia exception' that such an extraordinary woman - a nurse, statistician, outstanding feminist, pioneer of the defence of public health - as Florence Nightingale in the metropolis was insightful enough to unveil. Her astonishment at the answers given by the abbot of the wilderness to her survey on the health of the Aborigines of the Empire was the first recognition of the fact that there, in Western Australia, a Galician friar was challenging the racist practices of the Empire (Nightingale, 1863; Ride, 2007: 198; Shellam, 2012a). Aware of the new approach he was developing through hard learning in the field, Salvado went beyond mere practical, improvised, vaguely humanitarian knowledge in his contact with the Aboriginal world. In his document Information respecting the aboriginal natives of Western Australia, addressed to the colonial secretary, he stated,

To this hypothesis it may be said that after all there is more in it than a theory-indeed it is a theory [...]. Anyhow, that theory has regulated my operations here, and that hypothesis is nothing else but the same theory put here into practice in order to attain our charitable and heartily wished-for end, viz., the conversion and civilization of the aborigines of the province. (Salvado, 1864: 6-7)

Recent research on the Australian Aboriginal world and the new postcolonial narrative of 'contact and conflict' and 'assimilation', and even 'genocide' (Haebich, 2000, 2005, 2008; Rowse, 2002, 2012; Shellam, 2009, 2012b), has laid the foundations for a more exact reading of the abbot's work based on its specific difference vis-à-vis the 'extermination by neglect' approach (Haebich, 2004: 279). And this research has shown, with utmost clarity, why Nightingale's question, 'Can we civilize the Aborigines without killing them?' is so relevant. 
For their part, the natives' contemporary statements do not leave much room for doubt:

\begin{abstract}
The establishment of the Aboriginal mission at New Norcia had a profound effect on the lives of the local Aboriginal people, the Yued people of the Noongar nation [...]. We consider that Bishop Salvado was a friend of the Yued people [...] [who] had a deep interest and respect for Aboriginal people in which he recorded the local Noongar language, culture and customs. Those records have provided important historical information about Noongar people, including being used to support the Noongar native title claim. (Nannup, Drayton and Willaway, 2014)
\end{abstract}

Closely following the rule of St Benedict, Rosendo Salvado was acutely aware of the importance of making history. Almost obsessively he documented every aspect of mission, monastic, settlement and bush life around New Norcia, from the time of his arrival in the Victoria Plains in 1847 until his death in 1900. For social sciences researchers, the legacy of Salvado's history-making is evident in the New Norcia archive. We can read about early encounters between the missionaries and the Yued Aboriginal people on the threshold of colonisation through a variety of documents. We have access through New Norcia's archives to census records that Salvado made for the surrounding Aboriginal groups, the details of which tell a story about traditional Aboriginal life merging with Benedictine life - of Christian, married couples living amongst 'Bush Natives' and monks. There are mission diaries, personal letters and official correspondence, reports to the Propaganda Fide, circular reports about Aboriginal health, education and conversion to Christianity. Reading closely we can also catch glimpses of Aboriginal voices and actions captured in this European archive: petitions and letters were frequently written in their own handwriting, as Aboriginal residents began to use the new alphabetic literacy that they had learnt at New Norcia to voice their concerns and complaints, to express their ideas of what they were entitled to, or to simply write to Salvado to wish him a happy birthday when he was in Europe.

The New Norcia archive is a treasure trove of stories. Its complexity is enhanced due to a multiplicity of tongues in which the documents were written: Spanish, English, Italian, Latin, and, of course, we can occasionally glimpse 
Aboriginal English too. It is also rich in the way it covers so many diverse areas of colonial history, attracting scholars from a variety of disciplines, including religious and mission history, theology, Aboriginal history, musicology, art, Italian and Spanish studies, agricultural history, viticultural and environmental history and social and cultural history more broadly.

Aware of the importance of his own legacy-making, and with a need to raise funds for the mission, Salvado made his own 'official history' as early as in 1851, when he published his memoirs. These were first published in Rome in 1851 in Italian, then Spanish in 1853 and French in 1854. Resident brothers at New Norcia slowly took up their pens too, inscribing their own frameworks out of the documents created during the Salvado era. These insiders included the manuscripts - mostly unpublished - of Fr Flood - an Irish secular priest who lived at New Norcia for three years in the early 1900s - Dom William Giminez, Dom Romanus Rics and Fr Eugene Perez. These amateur religious historians offered a fragmented and partial beginning to the history of New Norcia. This scholarship was valuable, opening up small windows for outsiders to view the Salvado story. Writing from within the community in the early-mid twentieth century, these resident writers were entwined, in many ways, with the Salvado legacy - complicit in its creation and perpetuation. Indeed, one brother, Abbot Catalan, assisted in collecting information from the archive about New Norcia's Aboriginal residents for inclusion in a chapter in Hal Colebatch's edited book A Story of a Hundred Years: Western Australia, 1829-1929, published in 1929. As Tom Stannage described Colebatch's chapter: 'It is a hymn of praise to "pioneering" [...] with early difficulties overcome by energy and courage, patience and efficiency' (Stannage, 1993: 4). This era of historiography in Australia more generally was one of silence about Aboriginal past experiences, and these mission and colonial histories told a story which did not include Yued voices, actions or perspectives that the archive also holds (Stanner, 1968). They were histories which spoke of the glorious Empire and the heroics of men like Salvado who battled against a harsh and intractable environment, thriving against all odds.

It was not until 1977 that English speakers got access to Salvado's memoirs - rich as they are in ethnographic details and stories of early Yued encounters translated into English and edited by E. J. Stormon, published by the University 
of Western Australia Press. It cannot be underestimated how much the publication of this text into English projected New Norcia's story, and that of Salvado, into the minds of scholars and the wider Western Australian community. The publication in 1977 coincided with major historiographical changes among Western Australian historians (and historians across the world more generally), as the praises of Empire began to be rejected to be replaced with a focus on minority or historically neglected groups: women, Aboriginal people and the environment, for example (de Garis, 1993). Historians of the early twentieth century, such as J. S. Battye, praised Salvado and talked about the British Empire as Battye did in an uncomplicated way in his 1912 publication Encyclopaedia of Western Australia. He linked Salvado's legacy with that of other Western Australian pastoralists as an 'apostle of free enterprise'. However, following W. E. H. Stanner's 1968 ABC Boyer Lectures, in which he spoke of the neglect by historians of Aboriginal past experiences, historical interpretations began to shift. Therefore, when Salvado's memoirs were published in English, they were read by a mixture of scholars with diverse views about New Norcia and Salvado's place in the history of Aboriginal dispossession, colonialism and Aboriginal survival. A debate ensued amongst historians about Salvado and Australian missionaries more broadly: were they a force for harm or good in the lives of Aborigines? In what ways can we measure missionary success at the cost of Aboriginal cultural destruction? (Stannage \& Reece, 1981).

Following closely behind the publication of Salvado's memoirs in English and the criticism of Salvado that ensued, in 1980 George Russo published his biography Lord Abbot of the Wilderness: The Life and Times of Bishop Salvado (Russo, 1980). Russo wrote in a defensive style, praising Salvado for his missionary 'success' and all that he achieved as a pioneer. In 1991 Father Placid Spearritt, Prior Administrator of New Norcia, established an Archives, Research and Publications Committee, comprised of Western Australian historians, lay brothers and archivists who took on the role of assisting New Norcia to unlock its archives and collections to new scholarship, and to advise the community about long-term research and publication projects. The committee organised a New Norcia Studies Day, bringing scholars and the WA community together to learn about the archival records and history of New Norcia. A journal was published from the New Norcia Studies Day. In the first edition of the New 
Norcia Studies Journal (1991), one of the Archives committee founding members, Tom Stannage, had a vision of what future historians might attend to in the next wave of histories of New Norcia: 'the next history of New Norcia must be spiritually bound, intellectually aggressive and socially assured.' Such advice has been taken up by scholars since then (Haebich, 1988; Rooney, 2014; Reece, 2014). One of the most exciting publications to be released was the 1995 book A Town Like No Other: The Living Tradition of New Norcia, edited by Archives, Research and Publications Committee members David Hutchinson, Dom Christopher Power and Wendy Pearce. This was an exciting contribution to New Norcia's complex and diverse history, and included stories unearthed by resident brothers, historians and past Aboriginal residents (Hutchinson \& Pearce, 1995).

Histories in more recent years have given more complexity to Salvado's legacy as historians attend to the nuances of mission life and Aboriginal experiences amidst the crisis of Australian colonisation. Historians and social scientists in the last few decades have focused on Aboriginal cultural destruction and the keenness by some Aboriginal people to be part of mission life - these two themes do not need to be mutually exclusive. There has been a focus on the mastery of Aboriginal musicians, the astounding success of Aboriginal cricketers from New Norcia, and the way in which Aboriginal people found a sense of belonging among the brothers at New Norcia. Other stories about Salvado's legacy have not been ignored in this new scholarship, but tempered within new frameworks which attend to the transnational nature of missionary experiences and cast with an understanding about the racial discourses with which Salvado engaged (Hills, 2008; Shellam, 2012a).

Willing to rescue Salvado from stereotypes and even from the ignorance of many of the dimensions and the meaning of his work and progression, and focusing on this occasion on his (to a large extent) unknown indigenist efforts, the Consello da Cultura Galega organised the conference Rosendo Salvado e o mundo aborixe / Rosendo Salvado and the Aboriginal World, which is the origin of most texts included in this volume. The organisers' intention was to engage in an Antipodean dialogue about the abbot's work, bringing European and Aus- 
tralians researchers together to discuss different aspects of his life and work so that we could present an exact account of that unprejudiced 'on my way' with which Salvado burst, very energetically, in the very heart of the imperialism and colonialism of his time.

This book is arranged in two parts. The first part compiles the papers and interventions of the conference participants, while the second makes available to the reader a selection of texts by Salvado that may give direct access to his work and allow each individual reader to draw his or her own conclusions.

The chapters by Doireaan MacDermott, Ronald Berndt, Francisco Díaz-Fierros and Antonio Linage tackle, from different angles, Salvado's biography and the development of his work, highlighting his originality, the challenges he faced, the painful learning about the 'other', and the impact he made. Peter Hocking, New Norcia's archivist, shows the vast richness of the treasures kept in the Archives and the Library, founded by that exceptional abbot. Susan Ballyn provides an accurate overview of Aboriginal peoples in Australia and their struggles for recognition. Presenting Salvado's indigenist thoughts and practices 


\section{REFERENCIAS BIBLIOGRÁFICAS / BIBLIOGRAPHY}

Barry, Amanda et al. (eds.) (2008): Evangelists of Empire?: Missionaries in Colonial History, Melbourne, Melbourne University Press.

Cipollone, Giulio / Clara ORLANDI (2011): Aborigeno con gli aborigeni per l'evangelizzazione in Australia. Il testo della Relazione (1883) per Propaganga Fide del vescovo Rudesindo Salvado, Vaticano, Libreria Editrice Vaticana.

De Garis, Brian (ed.) (1993): Portraits of the South West: Aborigines, Women and the Environment, Nedlands, University of Western Australia Press.

Haebich, Anna (1992): For their Own Good, Nedlands, University of Western Australia Press.

HAEBICH, Anna (2000): Broken Circles: Fragmenting Indigenous Families, 1800-2000, Fremantle, Fremantle Arts Centre Press.

HaEbich, Anna (2005): «Clearing the Wheat Belt», en A. Dirk Moses, Genocide and Settler Society, New York, Berghahn Books.

HaEbich, Anna (2008): Spinning the Dream: Assimilation in Australia, Fremantle, Fremantle Press.

Hills, Stephen (2008): «The Grand Experiment of the Civilisation of the Aborigines: A Missionary Endeavour in Western Australia», en Amanda Barry et al. (eds.), Evangelists of Empire?: Missionaries in Colonial History, Melbourne, Melbourne University Press.

Hutchinson, David / Chris Power / Wendy Pearce (eds.) (1995): A Town Like No Other: The Living Tradition of New Norcia, Fremantle, Fremantle Arts Centre Press.

Linage Conde, Antonio (1999): Rosendo Salvado, Santiago de Compostela, Xunta de Galicia.

Nannup, Mary / Margaret Drayton / Paul Willaway (2014): «A Friend of the Yued People», en Benedictine Community of New Norcia, Rosendo Salvado, 1814-2014: Commemorating 200 Years, New Norcia.

Prada, Albino (2014): Crónica desde el país de los sin alma: Rosendo Salvado en Australia, 1846-1899, A Coruña, La Voz de Galicia.

ReECE, Bob (2014): The Invincibles: New Norcia's Aboriginal Cricketers, 1879-1906, Fremantle, Histrionics Publishing.

Ride, Anouk (2007): The Grand Experiment: Two Boys, Two Cultures, Sydney, Hachette Australia.

Rooney, Fr Bernard (2014): The Way of Boorna-Waangki: A Tale of Cultural Endurance, New Norcia, Abbey Press.

Rowse, Tim (2002): Indigenous Futures, Sydney, University of New South Wales Press.

Rowse, Tim (2012): Rethinking Social Justice: From Peoples to Populations, Canberra, Aboriginal Studies Press.

Rowse, Tim / Tiffany SHELlam (2013): «The Colonial Emergence of a Statistical Imaginary», Comparative Studies in Society and History, 55:4, 922-954. 
Russo, George (1980): Lord Abbot of the Wilderness: The Life and Times of Bishop Salvado, Melbourne, The Polding Press. [Trad. gal. (2001): O señor abade do ermo: A vida e a época do bispo Salvado. Trad. de Concepción Díaz-Fierros Tabernero. Santiago de Compostela, Consello da Cultura Galega].

SAlVADO, Rosendo (1851): Memorie storiche dell'Australia: particolarmente della missione benedettina di Nuova Norcia e degli usi e costumi degli australiani / per Monsig. D. Rudesindo Salvado O.S.B., Vescovo di Porto-Vittoria, Roma, Coi Tipi della S. Congreg. de Propaganda Fide.

SALVAdO, Rosendo (1852 [1946]): Memorias históricas sobre la Australia y la misión benedictina de Nueva Nursia, Madrid, Editorial Católica.

SALVAdO, Rosendo (1853): Memorias históricas sobre la Australia y particularmente acerca de la Misión Benedictina de Nueva Nursia, y los usos y costumbres de los salvajes. Trad. esp. de D. F. de D. Barcelona, Herederos de la V. Pla.

Salvado, Rosendo (1854): Mémoires historiques sur l'Australie, et particulièrement sur la mission de la Nouvelle-Nursie, París, Alphonse Pringuet, Libraire-Éditeur.

SALVADO, Rosendo (1864): «Information respecting the aboriginal natives of Western Australia», Western Australia, State Records Office.

SALVADO, Rosendo (1875 [entre 1875 e 1925]): La Nouvelle-Nursie: histoire d'une colonie bénédictine dans l'Australie occidentale (1846-1878). Trad. de Dom Théophile Bérengier. París, Pillet et Demoulin.

SAlvado, Rosendo (1977): The Salvado Memoirs. Ed. e trad. de E. J. Stormon. Nedlands, University of Western Australia Press.

SALVADO, Rosendo (2014): Memorias históricas sobre a Australia e particularmente sobre a Misión Beneditina de Nova Nursia e os usos e costumes dos australianos, Santiago de Compostela, Xunta de Galicia / Parlamento de Galicia / Consello da Cultura Galega.

SHELlam, Tiffany (2009): Shaking Hands on the Fringe, Nedlands, University of Western Australia Press.

SHELLAM, Tiffany (2012a): “"A mystery to the medical world”: Florence Nightingale, Rosendo Salvado and the risk of civilization", History Australia, 9:1, 110-135.

SHELlam, Tiffany (2012b): “"Our Natives” and "Wild Blacks": Enumeration as a statistical dimension of sovereignty in colonial Western Australia", Journal of Colonialism and Colonial History, 13:3.

Stannage, Tom (1993): «New Norcia in History», New Norcia Studies, 1, 4.

STANNAGE, Charles / Bob ReECE (eds.) (1981): European-Aboriginal Relations in Western Australia: Studies in Western Australian History, 8.

STANner, William (1968): After the Dreaming, The ABC Boyer Lectures, Sydney, ABC. 

SEARCHING FOR

ROSENDO SALVADO

IN 1978

Doireann MacDermott

Retired professor from the

Universitat de Barcelona

Doi: 10.17075/rsmaa.2016.en.002 


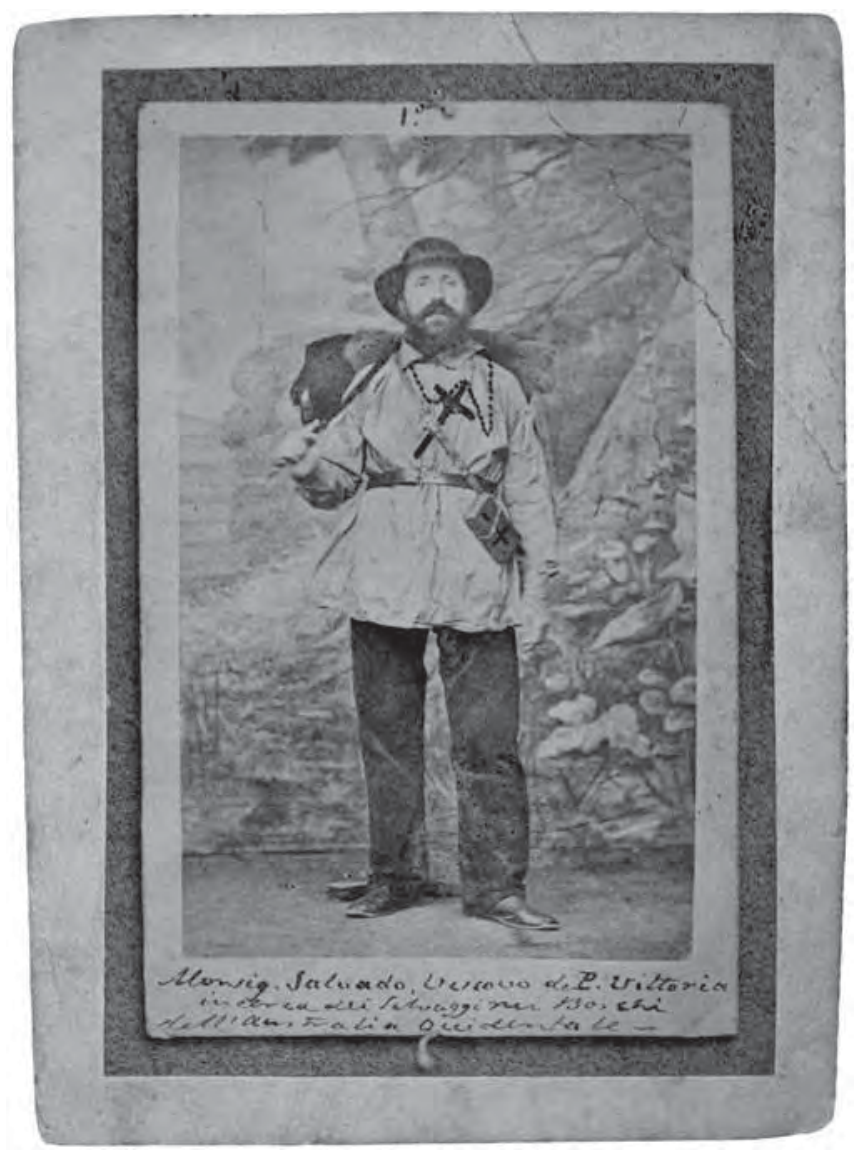


The year 1978 marks an important date in the now long and fruitful association of the Department of English Philology of the University of Barcelona with Australia. It had not been an easy task to introduce such an exotic subject as Australian Studies into our traditional programmes dedicated to the Cultures of Great Britain and the United States of America. But that year we initiated a great new project. Under the rather ambiguous title of Civilisation we would cover all the countries of the British Commonwealth considering the relations between colonisers and indigenous people. Australia was the first to be considered.

That year 1978 is also memorable as being that of my first encounter with the impressive figure of Dom Rosendo Salvado. By fortunate coincidence, a medical friend in Barcelona who was also a keen collector of rare books sent me a copy of the Memorias of Rosendo Salvado, written originally in Italian but available in a Spanish translation. I found it an extraordinary narrative written with exceptional verve and humour. Who was this curious character who had set his mind on going out into the wilds of the Australian bush, making contact with the Aboriginals and devoting his whole life to these mysterious and unknown inhabitants of the region?

I enquired and discovered that his abbey, founded in the mid- $19^{\text {th }}$ century with immense difficulties and setbacks, still existed and had grown and prospered under the wise rule of successive Spanish abbots. I wrote asking for more information and received a very friendly reply from Father Anscar $\mathrm{McPhee}$, librarian and custodian of the artistic treasures of the monastery. With him I established an interesting correspondence.

At that time Australia was pervaded by a curious phenomenon which the Australians themselves described as a "cultural cringe" - a sort of cultural inferiority complex, believing that their history and literature were not sufficiently known or considered in the rest of the world. So the news that 
Australian Studies were being taught in the University of Barcelona aroused the interest of Australian cultural authorities. We began getting visits from distinguished Australian academics. Presumably the information they took back was favourable because in 1980 I received a surprising and very generous invitation from the Australian government to visit their country. I was asked to prepare an itinerary of all the places I wished to visit. I sent a project covering a large part of the country but suggested that my first stop should be Perth, in Western Australia, with the idea of visiting the Abbey of New Norcia.

This rather unusual request attracted the attention of Professor Bob Brissenden, then president of the literary branch of the Australia Council in Canberra, and also that of Dr. Michael Costigan, with a similar post in Sydney. They had both heard of New Norcia but neither of them had ever thought of visiting it. The journey from east to west in Australia is very long but they both declared themselves willing to undertake the trip. They would meet me in Perth and accompany me on this adventure.

So we all met up in Perth: the two professors from the east together with Dr. Veronica Brady, a nun and lecturer in the University of Western Australia who was very well-known throughout the country as a fierce defender of Aboriginal rights. At that very time these people were embroiled in a bitter dispute with the regional government where strong mining interests were threatening sacred Aboriginal land. Also with us on this journey was George Russo, an Australian of Italo-Irish ancestry with whom I had also corresponded. He had written a book about Salvado which was not yet published at the time.

Travelling in two large, comfortable cars, the $120 \mathrm{~km}$ journey was interesting and agreeable, but we could not help thinking how arduous it must have been for Rosendo Salvado and his Catalan companion, José Benito Serra, on that first incursion into that wild "terra ignota" on rough paths with only an oxcart for their baggage.

In New Norcia I received a very friendly reception from the now reduced congregation of Spanish monks - visitors from Spain were rare. They were all rather old, the last vestiges of the Salvado era. They had been many years in Australia but retained a beautiful castellano and were still interested in their homeland. They subscribed to a Spanish newspaper. The conversation was animated until it suddenly took a rather melancholy turn when we thought 
about their being the last Spanish survivors. After their decease New Norcia would become wholly Australian and English-speaking. After Dom Rosendo there had been three more outstanding Spanish abbots. Now the current abbot Bernard Rooney, appointed in 1971, was of Irish ancestry.

I was accustomed to Benedictine monasteries, having in my childhood often accompanied my father to the Abbey of Quarr in the Isle of Wight, to enjoy the beautiful Gregorian chant. Later I had frequented that other great Abbey of Silos. I quite understood, therefore, that these abbeys were cloistered and much of their buildings out of bounds for women. Father McPhee was, however, determined for me to see at least some of the most valuable things that Dom Rosendo has brought all the way from Italy to enrich his abbey.

Later we visited the small cemetery, where 120 modest iron crosses marked the tombs of Spanish monks and also labourers and artisans imported from Spain to construct the abbey. These were mostly recruited in Catalonia and sailed for the far land from Barcelona. I took note of some names to report back to their relatives in Spain.

Having completed my stay in Perth, I moved on to Melbourne and went in search of Father Edward Stormon, a Jesuit who had recently, in 1977, translated the Memorias into English. I spent an agreeable afternoon with him at his home while we discussed that remarkable man. What had been the secret of his exceptional ability to gain the confidence and affection of those unhappy people whose ancient way of life, surviving for thousands of years in a harsh land, had so suddenly and so brutally been destroyed. For the white invader they were no more than troublesome vermin fit only for extermination or exploitation in hard white man's work.

Salvado was a highly cultured man, a fine musician, familiar with great works of art. A man of imposing presence and determined will. Like Ulysses, resourceful in adversity. Well liked and respected by his equals but also endowed with what Rudyard Kipling called "the common touch", a rare sensibility when dealing with simple or primitive people, on the line of those Dominican missionaries, Fray Tomás de Berlanga and his successor Bartolomé de las Casas, who centuries past had understood that, before converting indigenous people to a new faith and a new culture, it was necessary to study their languages and their beliefs and know the nature that surrounded them. 
Salvado had no special training in ethnology. He was an eminently practical man who knew how to make the best of the natural talents of these people. $\mathrm{He}$ admired their great manual skills, their artistic sense, their love of music and dance. He taught them how to dig wells and grow food. But above all he defended their right to exist and, as far as possible, adapt to this strange new world that had come upon them.

To conclude. One more thought. Certainly Dom Rosendo spent most of his life away from his homeland. But he was undoubtedly a gallego. In his childhood and youth he must have been familiar with that rural Galicia of Celtic origins where ancient pre-Christian traditions still survived: a world of spirits and superstitions and a close relationship with the land. Would this not be another element in his sympathy for his beloved Aboriginals? 


\title{
SALVADO: A MAN OF AND BEFORE HIS TIME*
}

\section{Ronald M. Berndt}

\author{
Professor of Anthropology in the University \\ of Western Australia
}

Doi: 10.17075/rsmaa.2016.en.003

* Published originally in E. J. Stormon (editor \& translator) (1977): The Salvado Memoirs: Historical Memoirs of Australia and Particularly of the Benedictine Mission of New Norcia and of the Habits and Customs of the Australian Natives / By Dom Rosendo Salvado, Nedlands, W. A., University of Western Australia Press, pp. 267-274. 


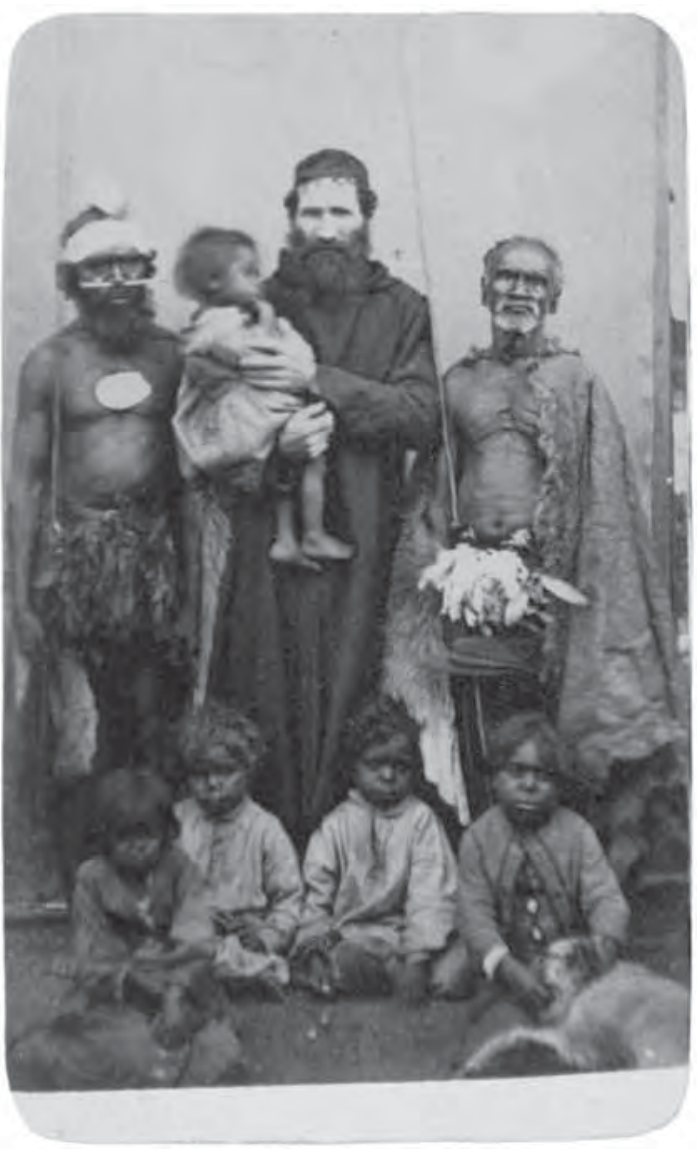


Bishop Salvado wrote his Memoirs during the formative period of our State's history. Sir George Grey had published his Journals in 1841, George Fletcher Moore his Descriptive Vocabulary . . . in 1842. With his missionary group, Salvado arrived at Fremantle in 1846. The Wesleyan missionary, Smithies, was operating a school for Aboriginal children in $1840^{1}$; there were other experiments, too (at Fremantle under the Anglicans) ${ }^{2}$. Salvado did not waste time. His initial depot was founded in the year he arrived in this State, and his first meeting with armed Aborigines (pp. 37-8) is an illuminating demonstration, not only of practical religion, but also of good sense and insight into human nature: it was pacification through the gift of food ${ }^{3}$. In 1847 the mission was moved to a site on the Moore (or Maura) River. Today, looking back at the hardships endured by Salvado and his companions - going into what was then virtually unknown territory - it is difficult to realize that it was only eighty miles north of Perth. Here he was in contact with Aborigines who had little or no knowledge of the European settlers.

Quite soon after his arrival at his first site, Salvado commenced learning the local language. He realized the importance of undertaking this task if he were to communicate with the local people, if any headway were to be made. He was certainly not unique among missionaries in this respect, but he was indeed rare among the colonists of that period: few recognized the vital need for this approach. With the use of notebooks, he began to record 'every word, with the meaning opposite', and, by this means, 'our knowledge . . . developed very

\footnotetext{
${ }^{1}$ An account of the early years of the Swan River Colony based on the letters of the Rev. John Smithies is being prepared in the Department of Anthropology, University of Western Australia. These letters were collected and assembled by the Rev. W. McNair, under the title 'Pioneer Christian: Western Australia's First Aboriginal Mission'.

${ }^{2}$ P. Hasluck, Black Australians (Melbourne, 1942), pp. 89-91.

${ }^{3}$ Salvado's moderate description of this meeting as described in his Memoirs is in marked contrast to the exaggerated account in New Norcia: The Remarkable Aborigines Institution of the Australian Commonwealth, the tribute of an Irish priest (London, 1908), p. 12.
} 
slowly' (p. 39). Appendix I provides us with a vocabulary: not in the sophisticated terms of today's linguists, but identifiable because he supplied the key to his orthography.

Bishop Salvado was a man of his own times: his attitudes and approach to the immediate problems facing him were reflective of those more generally held. But they also expressed more than this - he was intelligent and of an enquiring mind. On one hand, he wanted to know more about the Aborigines - not simply because this was useful in terms of evangelization, but because he saw them as being theoretically important. On the other hand, he was interested in them as persons, and had an appreciation of at least some areas of their socio-cultural life; and he was concerned about their contact with the settlers and about their place, economically, in the emergent European-dominated society.

Salvado, in these Memoirs, presents the reader with an ethnography of the local Aborigines. At the time when he wrote, Anthropology as a discipline was just becoming established. What we call 'the Convergent Period'4, between 1835 and 1859 , was just getting under way. Darwin had not yet published his Origin of Species (1859), nor Karl Marx his Zur Kritik der Politischen Oekonomie (1859). J. C. Prichard had published his Natural History of Man in 1843, and earlier his De Humani Generis Varietate (1808), to which Salvado refers. Prichard's work had an immense influence on his contemporaries, and this is reflected in Salvado's own work. There was an upsurge of interest in the ways of life of various peoples. Australia came in for its share of this during the first sixty years of that century, and Salvado's contribution must be numbered among the more important. It is true it is written in the idiom of that day, as one would expect, and it shows a concern with issues that are mostly less central to our problems (as ethnographers or anthropologists) today: the question of an Aboriginal divinity (p. 126), the concept of the soul (pp. 61, 127), patriarchy in relation to family life (p. 130), and - more generally - migration theories (p. 112), and a discussion on the races of man (Part 2) and linguistic variation (p. 112). These are to be expected; but the account is remarkably free from unrewarding theorizing or speculation: Salvado tried to adhere to the empirical facts. To obtain these facts, as I have noted, he

${ }^{4}$ T. K. Penniman, A Hundred Years of Anthropology (London, 1952), Chap. III. 
learned the local language and he tackled this study systematically. Moreover, and this I believe is important as well as being 'modern', he involved himself in what we call today (in our field-work seminars on methods and techniques) participant observation (p. 54). He recognized the need to intermingle with the people, to listen and to enquire. When the Aborigines were relaxed around their fires, talking among themselves, discussing daily events or plans for the morrow, telling stories or singing - at these times, much could be learnt. 'If the missionary knows how to make the best of this situation, he will learn far more in a single night than in months spent walking with them through the bush'.

On the other hand, Salvado was first and foremost a missionary - he came with a task to perform, to 'work among the natives', to 'convert and civilize'. This was all perfectly natural, as it still is in certain contexts - even though it may be framed differently these days. In speaking of the Aborigines' use of kangaroo fur skin cloaks (p. 70), he touched on the question of nudity. $\mathrm{He}$ admitted that this gave them no concern. But in order 'To begin the work of civilizing them, and to lift them above their wretched condition, we thought it wise to make a rule that whoever came to the monastery for soup . . . had to wear a kangaroo-skin. But we did not tell them the reason for this rule to avoid giving them feelings of shame'; they 'had no sense of shame', however, '. . . I have never been aware of any unchaste or improper action'. He perhaps comes closest to the conventional missionary attitude of the period in his statement (p. 84) about Aborigines whom he met in 1846, ' . . men who fled from the white man as from a savage beast, who were utterly unacquainted with work, who had no religious worship, and who thus worshipped no god, true or false (although they had an idea of an evil spirit)'. But he does write of 'Religious Beliefs' in Chapter 16.

At the same time, he mentions on several occasions his appreciation of Aboriginal life and of the people themselves. When making the road from New Norcia to Perth, via Bindoon, with a party of his Mission Aborigines, on the second day they met a number of Aborigines unknown to Salvado. He describes the meeting, which was highly formalized, expressing friendship between the two parties. Salvado notes that he 'was surprised to see demonstrations of courtesy that suggested civilized man rather than the savage' (p. 66). His account of the fire which threatened the corn fields and the miracle which resulted, is a 
further example. No sooner had the picture of the Blessed Virgin been placed before the approaching bush-fire, than the wind changed and the crop was saved (p. 67). Salvado records the attitude of the Aborigines to this event.

Or again, 'Often I have found natives who, in their physical beauty, their dignified gait, and in their bearing - which is that of an impartial and attentive observer - not to mention their facial features, which resembled those of Europeans, reminded me of persons whom one looked up to with respect in former times. Some boys of six or seven years of age, in particular, had limbs of such distinction and beauty that they surpassed the finest creations of Greek sculpture' (p. 116). Writing of Aboriginal poetic language - their songs - he says: 'I, on the many occasions when I have sat with them at the fire and watched their performance, enjoyed it no less than they'. 'Native music includes a graceful and beautiful style that makes one think of the Phoenician type, and a grave and serious one that makes one think of the Doric' (p. 133). But there were songs of amusement too. Salvado had an ear for music, as the concert he describes (on pp. 42-3) shows. This was held to raise funds for the mission. And although he does not mention this in his Memoirs, the volume written by an Irish priest in 1908 (p. 22: see note 3) mentions that he gave a rendering of a 'Black-fellow's Corroboree' to his own accompaniment on a piano. 'It completely brought down the house'.

The Aborigines he came among in 1846 were the Yuet (Juet), who occupied the area around New Norcia and Moora, Mogumber and the Moore River generally to the coast. Very close indeed to New Norcia were the Balardong, who took in Wongan Hills, Northam and York. Both languages are virtually extinct today, except for short vocabularies known by a few descendants of the people ${ }^{5}$. As social entities they have disappeared, the part-Aborigines who do survive are an admixture of those from other areas and Australian-European settlers.

\footnotetext{
${ }^{5}$ Salvado's language material in Appendix I of his Memoirs is arranged in three columns; the first is Yuet and the second probably Balardong. He has a further brief list in E. M. Curr, The Australian Race (Melbourne, 1886), Vol. I, pp. 318-21. It is interesting to note that the tribal term 'Yuet' means yuat, 'no!' It was quite common for terms like this to be singled out as tribal names distinguishing one group from others which used different words for (in this case) 'no'. W. H. Douglas's study of south-western languages,
} 
Little is known of the ethnography of these people, except from the writings of Salvado, Grey and Moore 6 . Daisy Bates did publish some social organizational material in 1905-06, 1914 and 1925, but these last are not especially reliable. In the Curr volume (see note 5), Salvado produced what he called 'a genealogical tree'. This is a drawing of a tree with six major branches, each relevant to what he called a 'family name'. The 'name' was inherited matrilineally, and marriage took place only between intermarrying groups: a person was forbidden to marry within the same 'name' and one or two others. This is a lucid statement of Salvado's and an interesting one anthropologically. Radcliffe-Brown did collect some 'scanty information' in 1910 but was not clear about the system: the information available is, unfortunately, not sufficiently detailed' ${ }^{7}$. The six 'family names' are not, apparently, sections ${ }^{8}$. Radcliffe-Brown speaks of exogamous moieties operating in this area, but from Salvado's data that seems unlikely, since the 'family names' cut across any rule of moiety exogamy. As both Salvado and Radcliffe-Brown suggest, these names represent matrilineal 'totemic' divisions (clans), each being associated with a 'totemic' creature or spirit being. Salvado's names are: Mondorop, Jiragiok, Tondorop, N-oiognok, Tirarop and Palarop. N-oiognok is probably Nagarnuk, named after nagarn, a small fish; and Palarop, Balarak, named after balard, a species of possum (see RadcliffeBrown, p. 217: there are also other translations). It also seems clear from

undertaken in 1965 when he was attached to the Department of Anthropology in the University of Western Australia, is particularly important in this context. (See The Aboriginal Languages of South-West Australia, Australian Aboriginal Studies No. 14, Linguistic Series No. 4, Australian Institute of Aboriginal Studies, Canberra, 1968, second ed. 1976; and the language of south-western Australia, in 'Aboriginal Man in Southwestern Australia', Journal of the Royal Society of Western Australia, Vol. 56, Parts 1 and 2, 1973, pp. 48-50.) Douglas classifies the New Norcia language as a dialect of Njungar (Nyungar) and states that it was called Tjapanmay (Djabanmai). He worked with an old Aboriginal woman who in 1965 was 'reported to be the only remaining speaker of this dialect' (p. 3). East of Tjapanmay was Watjanmay, of which no living speakers are known. In his Njungar vocabulary, Douglas gives the word yuwat or yuwad (that is, 'yuet') as meaning 'no!'

${ }^{6}$ For a brief outline of Aboriginal life in the south-west of Western Australia, see R. M. Berndt, 'Aborigines of southwestern Australia: the past and the present', in 'Aboriginal Man in Southwestern Australia', Journal of the Royal Society of Western Australia, Vol. 56, Parts 1 and 2 (1973), pp. 50-4, note particularly figures 2 to 4 .

7 A. R. Radcliffe-Brown, 'The Social Organization of Australian Tribes', Oceania, Vol. 1, No. 2 (1930), pp. 216-19.

${ }^{8}$ See R. and C. Berndt, The World of The First Australians (Sydney, 1968), p. 49. 
Salvado's statement (pp. 130-1) that territorial units (probably patrilineal) were significant. But he emphasized that the basic Aboriginal unit was the family, monogamous or polygynous; and, as we know today, this is (or was) true for all of Aboriginal Australia.

One of the most fascinating aspects of Salvado's ethnography is his discussion of the overall population of Aboriginal Australia (p. 114). He observes that, for the most part, such calculations are of little value. At the time he wrote, much of the continent was unknown to Europeans, and the Aboriginal population could be said to be 'unevenly scattered and wander from one place to another ad infinitum'. However, he puts forward an interesting view: 'it must be admitted that if we estimate the total population from the numbers ascertained in many particular parts of the country, we have to conclude that it does not exceed 300,000 '. Now, this was written prior to 1851 . Since that time, until the present, the same figure has been repeated. A. R. Radcliffe-Brown, in 1930, brought together all available evidence?. He systematically looked at various areas throughout the continent, and estimated that the original population of Australia was certainly 'over 250,000, and quite possibly, or even probably, over 300,000' (p. 696: see note 9). Elkin also suggested that in 1788 the Aborigines would have numbered $300,000^{10}$. I mentioned the same number, quoting from Elkin, and others have done the same. This is quite remarkable, and must surely be more than a coincidence. Salvado himself, as I have pointed out, suggested the figure tentatively and was quite unsure of it; and it is obvious that it was quite impossible to make any reasonably accurate calculation. But he gave it as a 'ceiling' figure. It should be possible now, with our knowledge of the number of Australian 'tribes' and language units over the whole of this continent, the varying socio-natural environments, the nature of semi-nomadic life and food collecting and hunting activities, together with the man-land ratio in certain regions, to come up with something better than this rough assessment - Salvado's and Radcliffe-Brown's. If Salvado is right, and recent anthropologists have validated that figure to some extent, it was both far-sighted and perspicacious on his part.

\footnotetext{
9 'The Aboriginal Population: Former Numbers and Distribution of the Australian Aborigines', in Official Year Book of the Commonwealth of Australia, No. 23 (Melbourne, 1930), pp. 687-96.

${ }^{10}$ A. P. Elkin, The Australian Aborigines (Sydney, 1954), pp. 10-11.
} 
The ethnographic material presented in these Memoirs is particularly interesting. Typical of the time in which he wrote, he considered the position of Aboriginal woman to be completely subordinate to her husband and in fact to all men (pp. 83-4). This is emphasized in his discussion of beauty in Aboriginal women and how disastrous that can be (pp. 139-40). Nevertheless, in spite of men's not interfering in women's quarrels (p. 83), and indeed in Aboriginal Australia this is an unwritten law, the revealing account of women urging men to defend their honour (pp. 167-8) gives the other side of the picture.

Cannibalism, too, attracted his attention (pp. 84, 162). He says that this was practised in times of extreme famine, but apparently did not witness any actual instances himself. On the other hand, again in cases of extreme need, so he reported, a recently dead person might be exhumed (p. 162) and eaten. References to exhumation (after three days and two nights) are very rare indeed in Aboriginal Australia ${ }^{11}$, although it was prevalent in parts of the Eastern Central Highlands of New Guinea ${ }^{12}$. Salvado's account, although not that of an eye-witness, has a ring of truth about it; he notes that the eating of the decomposed flesh could cause diarrhoea, and that the deceased's relatives would react violently against violators of the grave.

In discussing their religious life, Bishop Salvado emphasizes that Aborigines 'carefully [hide their] special habits and beliefs from strangers' (p. 125). To a certain extent, he was able to lift this veil. He speaks of Motogon (which he translates as God) as a creative being, and he draws an analogy with Genesis. He also speaks of particular myths (those of the Sun and Moon, for instance, and the Morning Star, p. 128, and also of the great Rainbow Snake common to so many Australia areas, living in particular waterholes, p. 128). But on much that one would expect within this category, he is silent. It is obvious, however, that he did hear sacred songs (speaking of these, p. 132, he says that some were 'handed down with a sort of traditional veneration') and see sacred ritual dances (pp. 134-5). As far as these last are concerned, he notes kangaroo and emu posturing and songs which refer to 'historic feats'. But balancing this is sorcery (the guardian spirit being apparently Cienga, a malignant character,

${ }^{11}$ We note no cases in R. and C. Berndt, pp. 400-3.

12 R. Berndt, Excess and Restraint (Chicago, 1962), pp. 183, 272, 284, 287, 289. 
pp. 126-7), and the native doctor (pp. 127-8, 170ff.), who is both sorcerer and healer.

Lack of space prevents me from commenting further on the wide range of material covering pregnancy and birth and infanticide (p. 136), marriage and betrothal, fighting and death. This last brings in some particularly interesting information on the treatment of the corpse, removal of nails, and the building of a but at the grave-side with reference to the deceased's soul (pp. 174-5). Probably the most detailed material is contained in Chapter 19 on methods of adornment, in Chapter 20 on weapons and tools, and Chapters 21 and 22 on hunting and food collection.

As I have said, Bishop Salvado was interested in all aspects of Aboriginal life, and not only the ethnographic. Especially, his concern crystallized around practical aspects of welfare. From the beginning, he saw that spiritual sustenance had to go hand in hand with material well-being (p. 86). His medical treatment, and some effective cures (pp. 50-1), paved the way. But he also provided portions of cultivated land from which Aborigines could harvest their crops and so purchase goods ('clothes, sheep, pigs and other animals', p. 82). His dictum is vividly expressed: 'It is no use saying that the native cannot appreciate the value of money, or take pride in possession; he rapidly learns to do both, and then he devotes all his energy to increasing his store of worldly goods and bettering his lot; but if he is made to feel only the burdens of civilized life and not the benefits, and his wages are so low that he sees no point in working for other people's profit, then he prefers the freedom of his nomadic life to the limitations of our civilization, and goes back to the bush' (p. 86). Much the same thing is said today well over a hundred years after Salvado wrote these words - in slightly different phrasing, but in essence the same; self-respect and economic viability, which are still sought for the remnant, part-Aboriginal population of these areas ${ }^{13}$.

Salvado spoke out, and firmly, against the treatment of Aborigines by the colonists, against their economic exploitation, against their neglect and maltreatment (p. 119). He offers examples of what can be done. He discusses their 'intellectual powers' (p. 118ff.) and suggests that 'there is every reason for

\footnotetext{
${ }^{13}$ See R. Berndt (ed.), Thinking About Australian Aboriginal Welfare (Perth, 1969).
} 
thinking that if these are carefully trained, they will succeed in every form of education both in the arts and the sciences'. 'The first thing to do is to teach him as quickly as possible how to fend for himself by means of agriculture or the basic trades, and after that one can improve his mind by forms of knowledge that belong to a civilized society.' These were cries in the wilderness at that time, and it was many years before something constructive was attempted on a broader scale. But he, and others like him, set the guide lines for future welfare activity, and our debt to them is great. However, it was not until about 1860 that the way was clear for progress at New Norcia, and its biggest role in this respect was played between the eighteen-seventies and the end of the century ${ }^{14}$.

From his Memoirs, Salvado emerges as a great humanist. Although this is a personal account, he does not sing his own praises: it is rather through his deeds and his words that we can gauge the man: deeply interested in the Aborigines around him, tempering his missionary zeal with practicalities, concerned for the material and spiritual wellbeing of those under his jurisdiction, and a defender of their rights - rights which were then barely recognized. He was a man of, and out of, his time: and it is because of this that his document is not simply one of historic interest, but has direct and indirect relevance for the present.

${ }^{14}$ Hasluck, in ibid., p. 98. 

RECOVERING THE MEMORY OF ROSENDO SALVADO IN GALICIA

Francisco Díaz-Fierros Viqueira Consello da Cultura Galega

Doi:10.17075/rsmaa.2016.en.004 


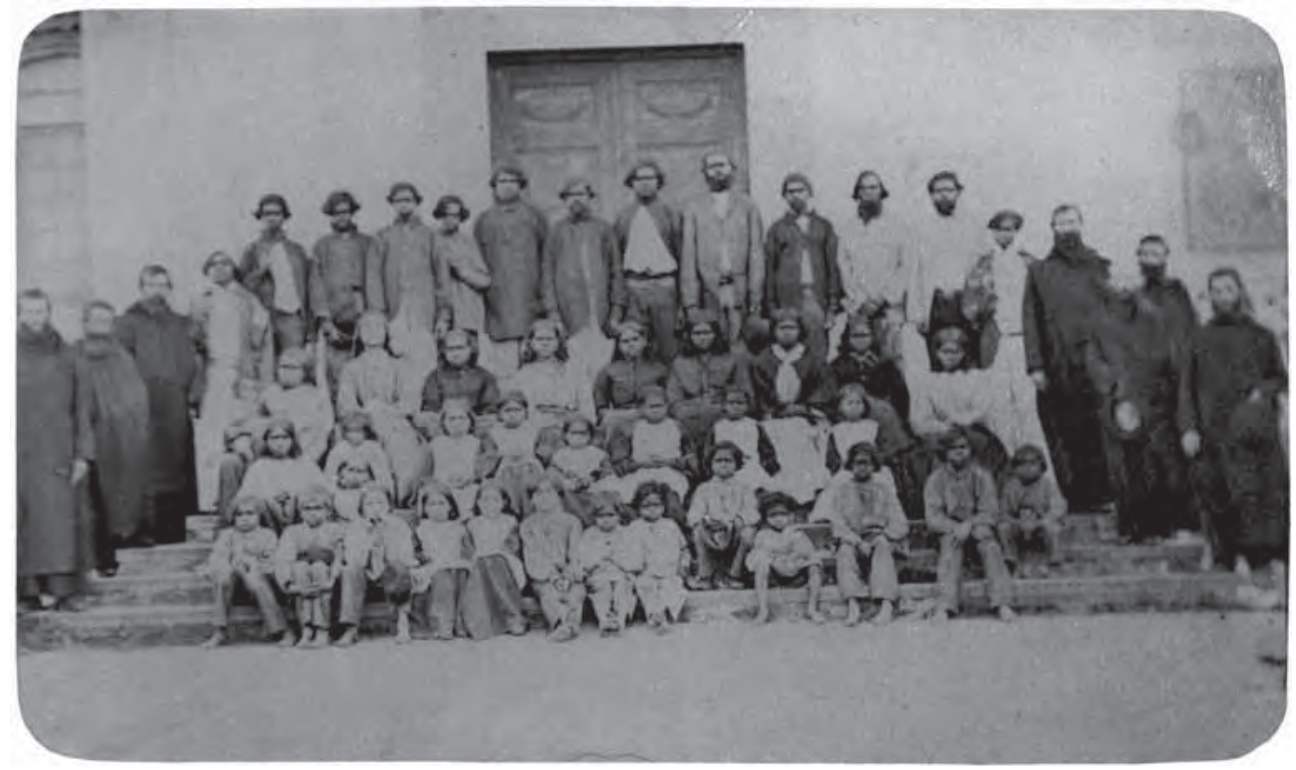


In a publication released in 2014 by the New Norcia Benedictine Community in Australia to commemorate the two-hundredth anniversary of Rosendo Salvado's birth, the representatives of the Aboriginal Corporation wrote:

The establishment of the Aboriginal mission at New Norcia had a profound effect on the lives of the local Aboriginal people, the Yued people of the Noongar nation [...]. Bishop Salvado had a deep interest and respect for Aboriginal people in which he recorded the local Noongar language, culture and customs [...]. In the spirit of reconciliation, we look forward to participating in events commemorating Bishop Salvado's life and his legacy.

This statement is enough to show the enduring recognition that this Benedictine from Tui enjoys in the hearts of communities that have been very harshly punished by history. Deprived of the most elementary rights, and decimated by disease and undernourishment, only with much effort and resolution did they manage, well into the twentieth century, to stand on an equal footing with the different ethnic groups and cultural legacies that make up the Australian population. Today, they are proud of their past and take much satisfaction in defending customs and traditions that - as they are well aware constitute the most genuine cultural foundations of that continent, one that is young and has a long future ahead of it, and which early colonisers, back in the $17^{\text {th }}$ century, named New Holland.

In Galicia, and even in Spain, Rosendo Salvado was well-known in his time. When he arrived from Australian lands, he would say humorously that there were 'no cats or dogs' that did not know what he was doing. He was often the subject of articles or comments, like those published in the first half of the $20^{\text {th }}$ century in Galician illustrated magazines such as Vida Gallega, La Temporada, Finisterre, etc. The memory of Salvado endured at least until the commemoration 
in 1945 of the centenary of his departure for Australia. That year saw the re-edition of his Historical Memoirs of Australia, the erection of a memorial in Tui and two cheers to his memory.

At an international level, researchers such as G. Cipollone, J. Á. Barreda and C. Orlandi, working in the Vatican Archives, or A. Haebich and T. Shellam, among others, working in the Archives of Australia, have in the past years brought back important traits of Rosendo Salvado's figure which confirm the value currently attached to his work as a champion of Western Australian Aborigines. The Australian people itself joined such recognition by dedicating a statue and a road in Subiaco, Perth, to his memory, as well as instituting the Camino Salvado as a pilgrimage route in 2009, following the model of Santiago de Compostela, in order to perpetuate the memory of this Benedictine.

In 2001, on the occasion of the centenary of Father Salvado's death, the Consello da Cultura Galega organised a commemorative exhibition in Compostela and published, in a Galician translation, the excellent biography prepared in Australia by George Russo. These activities were an attempt to partially make up for the oblivion the Benedictine from Tui seemed to have fallen into by then. For there were no longer many memories of him, apart from his supposed role in bringing eucalyptuses to Galicia.

We have made some progress towards this objective in the fourteen years that have gone by since then. But much still remains to be done. Little is known in Galicia about his culturising work, and even less about his odyssey: the profound challenges he had to conquer so that Australian Aborigines could be equal in their rights to Western colonists, and for the abbey he erected in New Norcia in the style of mediaeval monasteries to be (still today) a centre of living culture for its surrounding area. In sum, there is a lot our country ignores about a figure endowed with a unique personality, one that allowed him both to share the customs and traditions of Aboriginal tribes in the most distant spots of the jungle and to deal and negotiate with kings, queens and popes.

Current awareness of the genocides that, whether directly or indirectly, Western civilisation caused in colonised countries, as well as the feeling of guilt and redress that such genocides usually entail, should not prevent us from valuing the (usually heroic) endeavours of people like Las Casas in America or Salvado in Australia. Looking beyond their aim - evangelisation - they were 
able to recognise and defend the values typical of the human being and his/her rights.

In 2014, when we commemorated the two-hundredth anniversary of Father Rosendo Salvado's birth in the town of Tui, the Consello da Cultura Galega wished to remember the figure of this eminent Galician, once again, with different activities. Outstanding among these was the organisation of a commemorative exhibition that opened in Tui on 1 March, and later, on 3 April, in Santiago's San Martiño Pinario, the monastery where Salvado spent his training years; the exhibition was next taken to the Benedictine Abbey of Samos for the months of July and August.

The aim of this exhibition was, clearly, to highlight Salvado's work in favour of Australian Aborigines, and hence its name: Rosendo Salvado, valedor do pobo aborixe / Rosendo Salvado, a champion of the Aboriginal people. The exhibition brought to the fore the Galician Benedictine's resolute, brave attitude during his early contacts with the natives, and how tactfully, wisely and discreetly he immersed himself in their culture and traditions. Next to his missionary idealism, there was also his very unusual sense of organisation, which led him to plan in detail every single step that should be taken to build the Abbey of New Norcia and consolidate the agricultural holding used for its maintenance. There was also the insistence and decisiveness he had to deploy in his fight against the general feeling that Aboriginal communities were inferior ethnic groups and virtually hopeless for the cause of civilisation. And, finally, we could see how his generous, open, communicative character and his vast culture - as a humanist and music lover, but one who also had a plethora of technical knowledge opened up many doors to him and worked to soften the will of many who at first did not view his projects very favourably. In sum, he was a 'resourceful' man, as Professor MacDermott has aptly called him.

The narrative discourse of this exhibition was presented mainly in twenty panels, most of which included old photographs of Aborigines in the background. The author of these was another singular Tui-born man, Santos Salvado, brother of Rosendo. At the bottom of the panels, there was a word in the Aboriginal language, taken from the glossary compiled by Salvado as a result of his ethnographic research. All the panels as a whole described, in chronological order, the milestones of his culturising work for the Aboriginal people. They 
were like a succinct biography of the Benedictine, which emphasised those traits that might leave the strongest mark on the pragmatic minds of the dawn of the twenty-first century. The exhibition was complemented with a number of items of that time, which helped us visualise in tangible terms the dreams of a missionary who, as years went by, gradually adapted to the natives' material and spiritual world until he was like one of them.

To make this expositional effort a success, we had the invaluable help of the work and advice of Mr Avelino Bouzón, manager of the Arquivo Diocesano (Diocesan Archive), always kind and always ready to enhance the figure and work of Father Salvado, about whom Mr Bouzón knows virtually everything. Other people and institutions from Tui and the rest of Galicia also collaborated with the generous loan of different pieces for this exhibition. Among them, we should mention the Tui Town Council, which from the very beginning lent the Consello da Cultura Galega an efficient helping hand in the always complex task of setting up an exhibition like this. We must also mention the Benedictine communities of Trasmañó, in Galicia, and New Norcia, in Australia, as well as the Biblioteca Xeral of the Universidade de Santiago de Compostela (General Library of the University of Santiago de Compostela) and the prior of the Abbey of Samos, Father José Luis Vélez Álvarez, OSB. Our sincerest gratitude to all of them.

The year 2014 passed but, just as the activities of 2001 left their small traces in the process of recovery of the memory of an illustrious Galician, with that year's events we tried to take the final step to consolidate Rosendo Salvado's figure as one of the three singular Benedictines - in addition to Sarmiento and Feijoo - Galicia has contributed to universal history.

Rosendo Salvado was a great musician, an aspect of his biography that the Consello da Cultura Galega did not want to leave out of this celebration. $\mathrm{He}$ published his own art music for piano and commissioned a piece for percussion to Galician composer Antón Alcalde, inspired by the Aboriginal tune Maquielo, which Salvado transcribed. This was music used to give encouragement to Yued natives as they worked. There are other transcriptions of Aboriginal music which were made by Salvado and are still unpublished. These are all rhythms and harmonies that must have been present in the Benedictine's life as an 
affective landscape that probably worked as a vital framework for his heroic, difficult achievements. And so, as a conclusion, I believe that these words taken from a poem by Pere Casaldàliga might be a good summary of Rosendo Salvado's fecund pilgrimage across Australian lands: 'Turn your people's song / Into the pace of your walk'. 

ROSENDO SALVADO:

A BENEDICTINE ODYSSEY IN THE ANTIPODES

Antonio Linage Conde

Royal Academy of Jurisprudence and Legislation

Doi: 10.17075/rsmaa.2016.en.005 


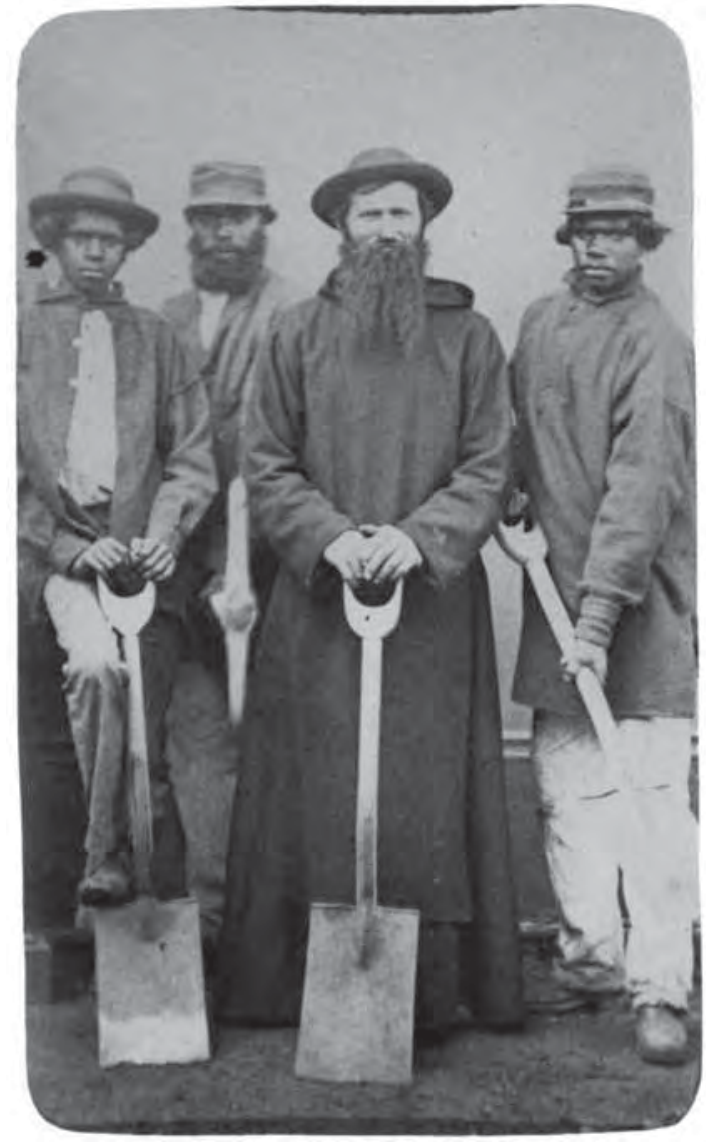


When poet Paul Claudel, after his return to Catholicism, heard the Magnificat being sung in Notre-Dame de Paris on a Christmas day, he spent a few days in the Benedictine abbey of Ligugé to ponder on a potential monastic vocation. There, not discerning any other way, he irrevocably felt that that one was not for him. After his death, which occurred quite a while afterwards, some of the scholars who studied his figure wondered what a Benedictine Claudel would have been like. The truth is that he felt perfectly comfortable travelling the globe and living in exotic countries - an environment that he found suitable for his work, with a biblically epic and dramatic flavour. What would, in other circumstances, the creative traces of his passage on Earth have been?

Benedictine monk Rosendo Salvado was a man endowed with outstanding aptitudes for personal success and for leaving his contribution to others in many fields of human activity. Suffice it to mention that he was offered a musicrelated position in the English city of Bath, simply because somebody had heard a concert that he performed in aid of the mission that he was planning, during a stopover on his voyage to Australia. His profane pieces, written when he was still in his native land, have been forgotten, mainly because of a lack of interest of the author himself, who fully devoted himself to his other vocation; but they could have, or actually have, a place in the history of Romantic composition. Moreover, if his elaboration of his experiences with his Aborigines has been appraised as surprising and progressive, bearing the circumstances in mind, by professional ethnologists, we may ask ourselves how far he would have gone if his dedication to that particular issue had been freer and more intense ${ }^{1}$.

Having said that, we should put on the other pan of the scales what would have been lost, for his time and for posterity, should our man have not been a

\footnotetext{
1 Although the exclusive use of scientific methods, without the cordial drive that guided him, might not have produced certain results.
} 
Benedictine monk. I am thinking of his community, of the two colleges, of that vast cloistral citadel that New Norcia came to be.

In this state of things, engaging in the assessment of the attainments and renunciations implied by the former and the latter situations would be indefensibly puerile. The path along which we can reflect upon the evaluation of the work performed by Dom Rosendo is a different one.

We should proceed on the basis that, above all, he acted and thought as a missionary of the Catholic Church, in full compliance with its dogmas and discipline. His ideal was to communicate the legacy and the message of the Church to the populations under his ministry, with a view to their conversion to Catholicism. The question that arises at this crossroads is whether this outcome did not require the renunciation of these populations to a part, rather than the whole, of their own culture ${ }^{2}$.

Respect for other cultures - except for the areas where these distance themselves from higher, unshakable human principles - is a value, and any aggressiveness in such field is to be condemned. Nevertheless, we must acknowledge that this does not imply that the influence of one culture on another culture is negative per se, as the former is also a bearer of values. Specifically, in the case of native Australians, the integral maintenance of their own culture was not possible after the creation of the new country by whites, except if they accepted what might have implied certain degradation.

But it would not be fitting for us to continue along the paths of these hypotheses, for it is actual facts that beckon. We will only yield to the temptation of reminding that the attainments of Benedictine Salvado were possible in the Benedictinism that found its way in monastic and ecclesiastic history in the phase of restoration and renewal that followed the almost total exclaustration that put an end to the ways of the Old Regime. But pondering what might have become of Salvado as monk in an intact Monastery of San Martiño Pinario, transplanting him to one of Mr Ramón Otero Pedrayo's evocations of those days and people, would be beyond tolerable in the context of these digressions.

2 With regard to Benedictine criticism of Salvado from this point of view, to which I will refer later, I remember hearing Abbot Spearritt say in New Norcia that such criticism might be due to a generalisation to all Aborigines of certain situations that were exclusive to some of their groups. 
We would simply want to bring to the reader's attention a position that, when it comes to judging exclaustration, has made its way even in the monastic sphere. Of course, that exclaustration is irrevocably condemned in such sphere, as it did not only suppress monasteries but also condemned the monastic ideal and monastic life themselves ${ }^{3}$. But, in terms of consequences, it is admitted that the exclaustration brought some purification, by making certain outmoded structures, and even indefensible states of things, disappear. What is evident is that Salvado's enterprise would not have been feasible in the preceding circumstances. This does not mean that such enterprise was directly due to the exclaustration; for what the latter did was, although unintentionally, close dead paths, rather than open new ones. If other monasteries had not subsisted in different territories when exclaustration took place here, Salvado's enterprise would have been impossible.

\section{OLD SPAIN IN YOUNG AUSTRALIA}

Evoking the paths that went down to Australia, and also the simple paths of this isolated land itself, is instructive for historians, and also simply suggestive for the spirit tout court. Above all, there is something humbling about it. What comes to our minds is, first, one of those gaps in historiography that come to be exasperating, and, second, one of the frustrations of history itself. For it has been shown that Chinese astronomers made certain observations from the Australian continent in the early centuries of our era. But we know nothing else about them. In contrast, we do have reports on the navigations of our fellow countrymen, deep-sea pilots, about what they themselves called South Land of the Holy Spirit, although they had not come to make it out; this exploit was reserved for their endemic English rivals, long afterwards. Once the discovery came to happen, it is the crossroads of ethics, chance and human will that acts as a stimulus to our reflective minds. For the conversion of the new continent

\footnotetext{
3 Some, nevertheless, attempted to find ideological coverage for a legal framework that tended to justify those measures of expropriation and consequential enrichment. In a way, just as those personal dictators who have invested themselves with alleged ideals unrelated to the seizure of power by them exclusively.
} 
into a penal colony and both the horrific framework in which the transfer of convicts took place and their living conditions there are among the black pages in the human adventure ${ }^{4}$.

In the mid- $19^{\text {th }}$ century, this system was being relinquished in Eastern Australia. That vast land had now seen the emergence of a 'respectable' society that, on the one hand, wanted to forget its past and, on the other, feared the arrival of new convicted blood (although convicts' forced labour, which benefited the colonists, had done these a definitely good service until then). Meanwhile, the whole of the immense west, a third part of the country - 'a body the size of Europe and the brain of a young baby' - was still virgin and unknown. From 1826 to 1831 , there had been a garrison in its northern area, where the city of Albany is now. North of there, also in 1826, another garrison that had settled on Melville Island, near today's Darwin, was quickly evacuated. And that was all.

It was the man in charge of such evacuation, a naval captain named James Stirling (1791-1865), who set the first colonisation enterprise in motion, although at the other end of the land - at the mouth of the Swan River, to which he arrived hugging the entire coast in a 4,300-mile journey. In 1829, the port of Fremantle, which is that of today's city of Perth, was founded in 1829. It was named after the captain who commanded the frigate that had been sent for such foundation, Challenger. And that was the first time that the name of Australia was used ${ }^{5}$.

But the dreams of prosperity turned out to be an illusion. By 1850 there were only 58,886 whites in the territory, with a deficit economy. For this reason, they had asked to be declared a penitentiary colony four years earlier, placing their only hope in convicted workforce. And so it was. This status remained in force since 1850 until 1868, the year when it was cancelled, to the outrage of the other colonies, which feared that they would be contaminated with its fugitive and freed men. By 1871, it had a population of only $25,447^{6}$. A few Benedictines

\footnotetext{
4 Robert Hughes (1989): La costa fatídica, Barcelona, Galaxia Gutenberg.

5 Curiously enough, London demanded that Aborigines be asked if they accepted this name, but communicating with them was not possible.

6 At that time, New South Wales already had a population of half a million, Victoria 7,300,000 (from only 77,000 twenty years earlier), the south 189,000, and Queensland 122,000. Tasmania, the other of the last penal colonies, was still stagnant.
} 
from old Spain in the Antipodes were by then paving new, successful ways in the solitude of that part of young Australia.

By 1836, all Spanish monasteries had been left empty and confiscated. A new type of man emerged then: the exclaustrated religious, whose vicissitudes greatly varied depending on each one's circumstances. A few of them managed to continue practising their monastic vocation in communities abroad; these, however, were scarce, as most countries in old Europe had already supressed them.

One of these religious was Rosendo Salvado (1814-1900), a man from Tui ${ }^{7}$ who had taken his vows in the Monastery of San Martiño Pinario, in Santiago de Compostela, and had been taken to the Monastery of Cava dei Tirreni, in the Kingdom of Naples, by another monk of his community who had already found shelter there: José Benito Serra (1819-1888). Salvado was a man endowed with fine sensitivity, a generous mind and diverse outstanding qualities - so much so that this is one of the cases of consecrated religious life that make us ask ourselves about the limits to comprehensive human development that religious vows may have imposed. The existence of such limits cannot be denied, but neither should we omit its opposite: the forging of the irradiation of his personality in a mould of spiritual aristocracy. One single fact should be enough. As Salvado passed through the English city of Bath, he performed a concert. And he received an offer to stay there at the service of music life. As simple as that.

Although they had been very warmly welcomed and were providing services that were appreciated in the Neapolitan monastery, Serra and Salvado's wish was to be missionaries in remote latitudes. And so they encountered their Australian fate when, in 1845, they happened to meet in Rome the Irish bishop John Brady, who led the brand-new Diocese of Perth. Incidentally, neither he nor his

\footnotetext{
7 Antonio Linage Conde (1998): Rosendo Salvado; or, The Odyssey of a Galician in Australia, Santiago de Compostela, Xunta de Galicia, with a bibliography. On the dreadful translation of the unpublished original, CUSACK, Aidan, in Hallel, 24 (1999), 146. Extending our considerations to the period that followed, we have dealt with this issue in San Benito y los benedictinos, Braga, 1995, volumes V, VI and VII ad vocem, and in Recollectio, 8-10 (1985-1987), 143-220, 291-348 and 175-239. More bibliographical references in MASSOT I MUNTANER, Josep (2012): 'La experiencia monástica de la provincia española frente al problema misionero: el caso de Nueva Nursia', in La Congregazione Sublacense: Inizi, ideali e attività missionaria, Barcelona, Publicacions de l'Abadia de Montserrat, 95-113 (repr. in Escriptors $i$ erudits contemporanis, Montserrat, 2013, 9-32).
} 
Anglican rival managed to have convicted workers build their respective episcopal palaces. We can give ourselves an idea of how primary the ecclesiastic geography was at that time if we consider the fact that Australia had been initially dependent on the apostolic vicariate called Cape of Good Hope, although it was located on the island of Mauritius. In 1818, Australia had been entrusted precisely to English Benedictines, the first of whom, William-Bernard Ullathorne, had had to immerse himself, like a dissident, in the horrible weave of those merciless years of deportation.

Brady, Serra and Salvado's journey to Australia lasted from 17 September 1845 to 7 January of the following year, and was made on the steamboat Elizabeth from Gravensend, at the mouth of the Thames, down to Fremantle Bay or Gage Road. As this was always a somewhat eventful journey, Salvado himself described both this and the previous ones in his Memoirs. For example: 'hardly engulfed in the Strait of Dover,' they rebuked 'infernal forces and the treacherous element.'

They departed from Perth in search of the location of their settlement, in the district of Victoria Plains, having been informed that there were quite a lot of Aborigines in the area. The adventure component, including contact with Aborigines, is obvious. The first encounter involved a large group of them, armed with spears. But the missionaries simply offered them bread, tea and sugar. Seeing the missionaries eat, the Aborigines did so. And they liked the sugar very much.

Even the trips to Perth, six to seven days in duration - although the distance was of only some seventy kilometres - were rather unforeseeable and dangerous. For example, during a certain trip that Salvado made with only his cart and his oxen, he had to grab them by the horns to take them across a torrent when the water reached above his waist.

In this state of things, his colonisation enterprise flourished. The Monastery of New Norcia was founded. Small houses were built to sedentarise the indigenous population, and the lands of the area were put in use (the wheat, wine and oil trilogy was rather biblical). These efforts were deployed from Greenough Flats and Arrino in the north to Gingin and Toodyay in the south and east. Of course, the missionaries had to do some mapping work and dig wells everywhere. 
Salvado's idea was to Christianise the natives and make monastic life amenable to them. Pope Pius IX himself bestowed the cowl upon two of Salvado's young men in Rome. This inevitably implied some acculturation. However, the contact with the white colonisers had made such acculturation inescapable at least to a certain extent; and we will leave aside here the criminal intentions that initially prevailed among these colonisers, and their lack of idealism in the best of cases. And so the accusation that Salvado was being ethnocentric should be qualified, even from the most rigorous point of view ${ }^{8}$.

Serra, for his part, eventually left the mission and the country in 1860. His ideal was to introduce Benedictinism among the white population, which was certainly more realistic at the time. One needs to bear in mind that, in the end, Salvado did not succeed in raising vocations among the natives, nor has there been any such vocation so far. But in 1856 he had written to Rome saying that his monastic citadel looked like a small Paraguay, alluding to the reductions that Jesuits had once had there.

Indeed, the traveller who visits the New Norcia Heritage Trail today will not find, first of all, a large monastery like the European and North American monasteries of the time, although the one in New Norcia did attain those proportions, and also their dense cultural refinement. Such absence of largeness is due to the dispersal of the buildings and the lack of any architectural mass that is excessively dominant (not even the church itself is). Due, in other words, to the fact that this is a small village, rather than a large monument.

Salvado wrote his Historical Memoirs of Australia in Italian, as a report for Vatican ecclesiastical authorities. The title is not suitable; it comes across as too modest. For it is a good ethnology book; as simple as that. And one can infer from it the author's appreciation of indigenous culture, which was by no means common among whites at that time. Ethnology itself was in its infancy ${ }^{9}$, in the

\footnotetext{
8 Marion Sitzmann (1987): 'Salvado's Missionary Endeavors for the Social Outcast of Early Colonial Australia: The Aborigines', The American Benedictine Review, 38, 127-38.

9 Ronald Murray Berndt (1977): Salvado: A Man of and Before His Time, pp. 267-274 of the English version, The Salvado Memoirs (E. J. Stormon [ed.] [1977], University of Western Australia). One also needs to bear in mind that this was a pioneering book in Australian bibliography. Basically, only George Grey's Journals and George Fletcher Moore's Descriptive Vocabulary were ever mentioned before this book was written.
} 
so-called convergent period, which lasted from 1835 to 1859 ; this is prior to Marx and Darwin's seminal works, though not to J. C. Prichard's Natural History of Man (1843).

Salvado died in Rome when the year 1900 was coming to an end. A fiftyfive years' stay in his New Norcia, then. But there is an odd detail about it one of those details that, in principle, are mere scratches on a piece of paper, but which come to be rather prophetic in the end. Serra had been appointed bishop of Port Victoria, a newly-founded city in the Bay of Essington, near today's Darwin, in the remote northeast. As a result of complications in the Curia, it was Salvado who assumed such episcopal title shortly afterwards but, before he could take possession of it, the colony was supressed by a governmental order. Nevertheless, Salvado kept his title until 1889, when the native population around New Norcia was becoming increasingly rare and, consequently, the missionaries felt a void. In this state of things, after Salvado's death already, the idea of filling such void elsewhere, and more specifically there in the north, came up.

\section{THE FRUITFUL CONTINUATION}

The monastic vocation of Dom Fulgencio Torres (1861-1914), an Ibiza-born man from a Jewish Christian family, was doubly late ${ }^{10}$. First, when he joined the seminary in Vich, he had already completed his degree in pharmacy at the Universidad de Barcelona. Second, when he took his vows in the Monastery of Montserrat, he was about to be ordained a secular priest. This - in particular, being invested in the habit - occurred in 1885 .

Around that time, Salvado had made this Catalan monastery the base from which he would recruit vocations in Spain. An Australian monastery could not even be dreamt of. This was beneficial to Montserrat as, in exchange for the requirement of founding a settlement in the Spanish Philippines, it was given

10 See Fulgenci Torres Mayans: Diaris d'un abat-bisbe d'Austràlia (Roma-Nova Núrsia, 1900-1914) (Montserrat, 2012); cf. Josep Massot i Muntaner: 'Fulgenci Torres, abat-bisbe d'Austràlia', in Escriptors i erudits contemporanis, cit., 33-101. 
naturalisation papers fully in line with the laws of the country (although this has never been clarified since the already remote exclaustration mentioned above). The foundation of such settlement in Hispanic Asia was somewhat delayed. Torres was among the first to be sent there, in 1895, but left very soon to take care of a small house belonging to Montserrat's congregation in Naples. Salvado met him there, shortly before his death. And it immediately struck him that he was seeing his successor in Torres. As eventually happened. The community, which he had already led for a while, unanimously chose him as abbot in 1902. And this was the man who was to take the Aboriginal mission from the southwest to the north end, thousands of kilometres away - but also into an unknown territory, so choosing the place required actual exploration work first.

Unknown and isolated. This is why the monks who eventually chose this retreat tended to qualify a little the legendary admiration that the initial enterprise in New Norcia elicited. New Norcia never lacked contact or communication with the pre-existent white establishments in the area, which was already known and had begun to be subjected to colonisation. By contrast, the northern area, poorly communicated, implied loneliness among a native population that, perhaps owing to that very loneliness, was much less approachable and even hostile.

However, as the author of the prologue to the foundation's history ${ }^{11}$, Hilton Deakin, says, while 'the difficulties they were to face required the stuff of which heroes and heroines are made,' those Benedictines actually 'had their heroes and heroines in the priests, Brothers and Sisters who staffed the mission,' in 'such unique situation' that the prime minister of that state, Charles Court, described next.

The Drysdale River Mission was established in Pago in 1908 and transferred to Kalumburu, a little to the southeast, in 1937 . The maps presented by the airline Qantas to its passengers mark this place ${ }^{12}$. Few of the Spaniards among

\footnotetext{
${ }^{11}$ Eugene Perez (1977): Kalumburu: The Benedictine Mission and the Aborigines, 1908-1975, Kalumburu, Kalumburu Benedictine Mission.

${ }^{12}$ Brockman had recommended in 1901 that a harbour be built at the end of the Anjo Peninsula; in other words, not far from today's Kalumburu.
} 
them are aware that this new point on the map is there thanks to some fellow countrymen. The spot is located 135 miles northwest of Wyndham, on Napier Broome Bay, into which the King Edward River discharges, north of the region of Kimberley. Seven miles from Kalumburu, the King Edward River and the Carson River converge in Argon, forming an islet forty feet high as they reach the mission. In the course of time, the top of the islet was once left at the mercy of the waters, so the tomb of a monk who had spent fifty-three years on the islet - Rosendo Sosa's record - was dragged by them; his body came to flow for some time until it submerged into the shrouding earth. The area has a monsoon, cyclonic climate. Temperatures oscillate between 20 and 36 degrees Celsius. The land is volcanic, sandy, close to being barren, but the mission is like a fertile oasis where fruit can be grown and cattle can be raised. The vegetation is that of tropical savannah, with two predominant varieties of eucalyptus.

The commission that New Norcia should found the aforementioned establishment in the north was given to the new abbot in 1905 by the Plenary Council of Sydney. His first coastal exploration voyage took place the following year. Its significance in the geographic history of the west could compare, without exaggeration, to the most famous voyages there: those of the Forrest brothers, Parker King and F. S. Brockman. The latter's voyage served as a basis that guided Torres: Brockman had inspected Cambridge Gulf between 1882 and 1891, and his inspection had just been made the subject of a publication in 1901. This predecessor of Torres had followed the course of the Drysdale River down to its estuary, discovering then the source of the aforementioned King Edward River and exploring the entrances of Admiralty Gulf, Vansittart Bay and Napier Broome Bay.

Torres, for his part, left Fremantle on Bullara, a 1,725-ton vessel, on 27 April; on 7 June he embarked on his return journey to Perth through Geraldton. In the meantime, he made his own 'discovery' voyage to a certain extent. With a view to establishing the foundation this time, he left on the same ship again on 18 June of the following year; he departed from Geraldton and did not return to New Norcia until 1 October, but he spent most of that time on land, laying the foundations of the new apostolic post and in contact with the native population. There stayed a Trappist who had not left the area when an attempt by his order to establish a foundation on Beagle Bay was abandoned. This 
Trappist was Nicolás Emo, who also wrote a diary that complements the abbot' $^{13}$ in certain aspects that the latter omits.

The exploration began on 11 May on a small 14-ton ship, San Salvador, for which Captain Johnson was hired together with four Philippine crew members. Hardly had they left Broome for Wyndham when they had to constantly face shallows, sandbanks and small islands. The coast had not been mapped, and the British Admiralty had warned the abbot of the incessant danger. Only Aborigines were familiar with the coast. One of them accompanied the explorers on their boat, and was filled with nostalgia as they sailed away from the bit of land that was his home. For Aborigines were sedentary to an extent hard to conceive for us. Their provisions were becoming scarce. On the day of Pentecost, the abbot was satisfied with a dish of rice and then spent two weeks on bread and water so as to save for the others what little food was left over time. Apart from indicating strictly geographic data, such as the immense reef between Long Island and Mary Island, sometimes the diary does not omit to openly state the terror with which that unknown sea inspired them. They arrived at Wyndham on 15 June. Torres performed a concert for them. The one that Salvado had performed in Perth half a century earlier became a golden chapter in legendary history. Both facts show how common musical taste and training were among churchmen at the time.

Once the initial site for the mission that we mentioned above had been chosen, although only generically, in June 1908 they made the second voyage on the same vessel, now with a view to effectively founding a settlement. They also carried Mary, a small boat, with them. The native population in their area of influence would be made up by two tribes, the Kwini and the Kulari; the former covered the area from the King George River to the King Edward River, and the latter from the King Edward River to Cape Voltaire. The first monks assigned to this settlement were Fathers Planas and Alcalde and Brother Vicente. Trappist Emo remained with them. They had also taken a married Aboriginal couple and five youths with them, as well as another married couple made up by a Philippine man and a Timorese woman, with a twelve-year-old girl whom

${ }^{13}$ The Diary of Bishop Torres, 1901-1914 (Eugene Perez [ed.]; Kalumburu, 1986). 
they had adopted in Broome. The cargo amounted to seventeen tons, and they had to divide the expedition in two parts. To sum up, the specific purpose of this expedition was to inspect the last stretch of the Drysdale River. The Assumption of Mary was the day chosen for the solemn birth of the new house.

On 1 October, Torres was back in New Norcia after one hundred and three days of absence, a period in which there had been a genuine armed clash with the natives (around thirty of them). Having been warned by one of his companions, who were natives as well ${ }^{14}$, that the natives' attitude in surrounding the strangers was a preparation for 'war', the Philippine man in the group repelled the attack with shots. 'We were lucky that the natives did not use their Boomerang,' the abbot wrote. We should bear in mind that Salvado and his people did not have to face any similar event in the southwest. The beauty around him had, at certain times, reminded Torres of the now long gone views of Capri. And, as a coda, he wrote that his experiences in those three months would have fulfilled the expectations of the man who most aspired to them.

\section{FROM PAGO TO KALUMBURU}

Almost a century has passed since then. And the history of this century has certainly not been lacking in changes! But we have arrived in time to meet in New Norcia one of the surviving Spaniards from the community, which was initially made up exclusively by men of this nationality: this was an Aragonese man from the Diocese of Lérida, Dom Mauro Enjuanes, who has a passionate admiration for Father Alcalde - whom he came to meet - and keeps a handbook on morals, copied in his own hand, in memory of him. This used to be done on occasion so as to avoid the cost of a new book.

How scarce the earliest contacts with the much longed-for aborigines were and the way in which such contacts were made are revealed by the fact that,

\footnotetext{
${ }^{14}$ It appears that the event that triggered this was the imprudence of another of them. A young woman was said to have died during the incident, but no such thing is included in the diaries; these only mention that a man had been wounded but was still able to flee unaided, and did so immediately, just as everybody else.
} 
when Torres was still in the community, it occurred to him that he should leave some pieces of clothing hanging from the trees so as to attract Aborigines. On 27 September 1913, one hundred and three of them attacked the monks and their people, surrounding them while the latter were sharing out some watermelon; the slaughter was prevented by the shots in the air fired by the Philippine servant ${ }^{15}$. Years later, the aforementioned Father Alcalde, one of those who had been speared, had intermittent nightmares in which he figured himself in the same situation again. In the immediate time period, reports from certain informers about the native population's intentions to pursue peace or wage war, and also the constant donation or theft of fruits and vegetables and cattle, constituted the human landscape of the mission. Some who had stolen a woman from another tribe or group would come to the mission from time to time. Women were scarce, and this was enough to lead to a permanent state of war. There were occasional attempts to make the monks the arbiters of such a situation.

The only means of communication was the maritime one, except for the explorations of the surrounding land. For this reason, in 1919 the mission bought the first of their own little boats, Voladora, of nine and a half tons. Radio communication was achieved in 1927. Even today, postal service airplanes arrive regularly only once a week, apart from some other non-scheduled airplanes carrying provisions. In that situation, a warship docked there in 1916 and informed the community that Australia had entered the great European war. Some gifts were exchanged between the sailors and the monks. In February 1931, the monks saved the lives of two German aviators, who had been forced to land their Junkers Atlantis in the proximity. Hitler sent the monks a harmonium as a present ${ }^{16}$.

In the meantime, the monks gradually became familiar with Aboriginal folklore and beliefs and acted as doctors for Aborigines, often to heal the wounds that they had sustained in their fights. They also tried to learn the Pela dialect,

\footnotetext{
15 On 27 August 1926, the Governor-General of Australia and his retinue were on the verge of being attacked in front of the monks. It was their first visit.

${ }^{16}$ It has been preserved until this day, although, paradoxically, it was damaged during the bombardment that we will describe later.
} 
a variant of the Kwini language ${ }^{17}$. But the chronicle of the house states for 19 February 1922, 'One death after another, and no births.' The chronicler mentioned this fact alarmed at the announcement that this race was bound to disappear. We will enlarge upon this subject later.

The transfer to Kalumburu finally took place in 1931, and so the much longed-for establishment of the mission by the Drysdale River became true. There were female Benedictine missionaries from that year on. The chronicle said for 23 August 1935, 'We must not be surprised at the great attraction that the jungle and the life in it hold for Aborigines, if we do not lose sight of the fact that they also hold intense appeal for us whites.' A total of one hundred and six natives, fifty-one of whom had been Christianised, were already living at the mission in that year.

The year 1939 saw the arrival of a monk from Navarre, Serafín Sanz de Galdeano, born in 1913, who would eventually pen an unpublished ethnological study ${ }^{18}$ that we will use as guide hereafter. In addition, now that the World War had already been declared, a military airfield was, quite senselessly, built by the neighbouring mission, and would inescapably imply the death of the latter. Indeed, on 27 September 1943, exactly thirty years after the Aboriginal attack described above, the mission suffered a Japanese bombardment that destroyed it and killed the Superior, Dom Tomás Gil, as well as a native woman and four native children.

These Kimberley natives were very sociable. Circumcision was an initiation for them. They had a confused idea of a higher being, but one that lived diffusely among many good and bad spirits connected with the animal world. Only dogs were considered members of the family and buried like humans. The natives saw no continuity between the human mind and the entire material world. Therefore, their classification of the fauna and flora of their area as they knew them was a sui generis one.

\footnotetext{
${ }^{17}$ Dom Sanz de Galdeano is the author of the unpublished Pelà-English Language Dictionary and Grammar Used by the Kuini Tribe of Kalumburu Mission (1996).

${ }^{18}$ Metamorphosis of a Race: Kuini and Kulári Tribes of Kalúmburu Mission (1998); also Memoirs of a Spanish Missionary Monk: Dom S.S. de G., O.S.B., M.B.F., O.A.M., C.S.M. (1999; a foretaste, Vida y milagros, was published in Bogotá in 1986).
} 
Meanwhile, New Norcia had attained a splendid development, which included a large monastery with a robust, extensive farming and forestry property, as well as the pastoral irradiation that was expressed mainly through two colleges, one for men and one for women: St Ildephonsus and St Gertrude. A large library, of course; artworks were not neglected either. For there were not only monk writers, but also monk artists. But almost all of this was intended for the white population, while the other one had become very scarce. More about their world will follow, enlightened by the example from the north that we mentioned earlier.

\section{INTERNAL CRITICISM}

In Primo de Rivera's time, the little boy Serafín Sanz became a Benedictine postulant in El Pueyo, on a superb mount near Basbastro. The abbot who succeeded Torres, Anselmo Catalán, who was also from Navarre (from Corella, specifically), had already gone there to attract vocations, and moved his listeners when he told them about the 'poor savages' in Australia. Serafín's father was beside himself with joy when he found out, aware that Australia was even farther than the most remote goals attained by St Francis Xavier from Navarre in his missions. Commenting on his profession of faith, made on 21 March 1935, he wrote in his memoirs: 'I felt happy living the monastic life, as the bird born in captivity is happy in his cage.'

And upon arrival at the mission, which he assured was the most isolated one in the world ${ }^{19}$ :

In Pago, the women did not constitute a collection of belles, as a result of their hard lives in the jungle and the even harder treatment that they received from men. There were

\footnotetext{
${ }^{19}$ Such isolation was not only geographic: 'Social isolation was almost complete: the Aborigines were not company, since their ideas and interests were very limited, and they usually acted with indifference unless one discussed hunting or killing with them.' He also missed New Norcia's solemn liturgy. Loneliness was even more intense because of the need to maintain Pago for their own little boat to have a place to dock: only one monk was still there. They took it in turns to stay there for two weeks, but Dom Serafín remained in the place voluntarily for an indefinite period.' However, '[a]s a matter of fact I was completely happy, and therefore it was too good to last.'
} 
among them women with broken fingers, broken arms, broken legs and broken heads. But, as they did not know anything better, they felt happy enough. Same thing in Kalumburu, where those who represented Aborigines' survival and future remained. With a group of twelve children of both sexes, some - or perhaps even most - of whom were alive thanks to the missionaries.

Going back to what was the state of things around the time the foundation was established, in 1908, Sanz's conclusion is that these natives, approximately seven hundred with the visitors included in the census, were indeed the survivors of a dying race. Interpreting this fact, when it was interpreted correctly, was decisive: the missionaries did not trust the natives' friendliness because the latter would never come to them with their children. Until the missionaries realised that the reason was the natives' virtual lack of them. Shortly before that time, the natives had devised a birth control method - mángar - consisting in cutting - the cut, nyángal - the urethra in the penis - mári-near the scrotum, which made conception difficult after copulation, or yun. Also, the scarce women there were sexually abused from too young an age and by too many men. In terms of homicides, a total of 44 were counted between 1918 and 1928. It is interesting, however, to note Sanz's initial assertion that, 'in their natural state, the Aborigines whom I met embodied a fine, dignified example of humanity.'

One should examine Dom Sanz's statement about this race in itself and the consequences of its contact with the white population, on the one hand, and the consequences of its members attaining full Australian citizenship in 1967. This implied their admission in the social security and, in Dom Sanz's judgement, excessive abundance of money, as well as the consequent end of the tutelage that the missionaries somehow exercised over them ${ }^{20}$. And one should acknowledge that Dom Sanz's remarks are, above all, commendable for being the result of a long direct experience as virtually no other observed has ever had. In view of all

\footnotetext{
${ }^{20}$ We transcribe here, without any commentary, his initial gloss to the presentation of that last part: What does it mean to be independent? To me, it means not receiving orders from anybody and not needing anything from anybody. And, in both senses, no human being can eventually be independent. For only One is independent: God. But, leaving philosophies aside, how did Kalumburu Aborigines actually gain their independence when the Benedictines stopped taking care of them? The truth is that the so-called dependence on a few missionaries was replaced by another type of dependence on many more others who were not missionaries.
} 
this, not only is Dom Sanz's account valid to illustrate this very ethnological redoubt, but it is also quite symptomatic of analogous situations at this point in history in the context of contemporary democratic politics, i.e., the decisions made in relation to it. This account is also instructive, as it serves to moderate significantly any rambling expectations that prevent one's principles from being tempered at the contact with practical requirements or, at least, inescapable realities. On the other hand, presuming good faith on the part of politicians and administrators involved in governmental measures relating to this matter, if any, should not come to change our objective judgement of the facts and an evidencebased assessment of these.

Notwithstanding the above, in Dom Sanz's severe criticism - based on his privileged, very lengthy first-hand observation - of anthropologists', and even politicians', prevailing interpretation of the Aboriginal world, one should not fail to notice certain intransigence on his part in not applying certain analogies involving Aboriginal culture to other cultures, even our own (irrespective of how different they are), as if demanding, rather, literal concordance between them.

On the other hand, one must not omit the fact that Australian Aborigines hardly have any cultural elements in common. In the case of many uncommunicated tribes, with a very limited area of operations in their lives, their linguistic pluralism is the best sign of this ${ }^{21}$. So those who have studied tribes other than the Kwini and the Kulari may have legitimately reached different conclusions from our Kalumburu missionary.

With regard to religion, Sanz believed that his natives did not have any word with such content to designate it, even if ethnologists thought that they had detected certain richness in the religious field, to the extent that even the pope praised Aborigines for their great spirituality. In this regard, Sanz noted the need to know their language, and also noted the danger that, once they came into contact with the civilisation and religion of whites, they might extrapolate their previous beliefs to some of the newly learnt ones. For example, those ethnologists hold that the natives' god is Uáloro. Having asked an intelligent Aborigine who this god was, Sanz received this answer: 'He has a wife and a son, so he is the

\footnotetext{
21 Their languages have been divided into families according to the criterion of whether or not they share the word to designate man.
} 
Holy Trinity.' Sanz also denied that Gnaui was a spirit, stating that it was just breath. And he rejected to narrowingly classify the natives as totemic animists, as they showed no respect for their tribes' totemic animals when they hunted. He did not think it was possible, either, to talk about Aboriginal law, or sacred Aboriginal places, but only secrets that only initiates could access on pain of blindness or other, even worse penalties, imposed by the spirits that the natives believed dwelled in them. But does not that terror imply the recognition of something sacred? Does not the same notion pulsate in such secrecy? More controversially to us, Sanz refused to attribute the natives the ability to tell good from evil, claiming that they would only make such distinction because of its repercussion in their social environment. For one should not lose sight of the fact that certain societies are articulated in such a way that they are able to polarise the ethical criteria of their members so that these criteria will penetrate their private conscience, much as if there was no division in our Catholicism between the internal forum and the external forum that are so well known by canonists. And what would we say about Islam?

In contrast, and from a worldly perspective, Sanz stated that their material culture was less simple than ethnologists had claimed. For example, the natives cooked their food more or less depending on the type of food, the conditions of the fire and how hungry they were; it was not true that they always ate their food raw.

The belief that those two tribes were endangered was not, however, a personal opinion of our Benedictine from Navarre, but one that was shared by all the other missionaries until 1940.

In the meantime, acculturation had been taking place around Kalumburu at the contact with the mission. By 1945, only two men continued living in the forest, one of them with seven women; the monks never came to meet any of these women. Most other men lived permanently around the mission. When, after the political tide changed, the civil servants sent to the mission asked those men if they wished to go back to live in the forest, one of them answered that he did - but only for a couple of weeks and with a rifle.

The consequential increase in the natives' wealth and standard of living was the result of improved hunting and fishing procedures and better horticulture produce. 
Naturally, that freely accepted coexistence required the submission to a law that was also criminal law. Caning existed, although it was rarely applied - for example, to those who fought - and this penalty was carried out with the same discipline that Benedictines would use for themselves then. Discretionary dance was the existing entertainment.

Polygamy and the exchange of women, with the endemic pugnaciousness that they implied, were a barrier that prevented the missionaries from accepting Aborigines into the bosom of Christendom through the administration of baptism. The first such baptism did not take place until 1920, and occurred only because it was a suspected case in articulo mortis. But approximately half of them had already been baptised by 1939, and a number of canonical marriages had been solemnised.

The acculturation requirements ${ }^{22}$ involved clothing, housing, farming the land, learning a trade and gaining a certain sense of law and order, as well as hygiene; the supreme religious aspiration was left aside ${ }^{23}$. This was, quite clearly, a heavy burden for these people, regardless of both their intentions and the material outcome: 'For Aborigines, their settlement at the mission involved changing their way of life ${ }^{24}$. By contrast, laziness at work was not a constant vice of theirs.

What was inevitable was the erosion of the values of their old spiritual culture, including their language: 'Young people had to learn many new words

22 Of course, and above all, giving up the two practices mentioned here on which Dom Sanz blamed the lack of births. He pointed out, in this regard, how decisive it was for nuns to arrive in 1932, especially for the fertility of young Aboriginal women.

${ }^{23}$ Dom Sanz noted how difficult it was to make them understand the mysteries, for the obvious reasons that the indoctrinators did not understand them either. This is why the catechism, the biblical summary and the prayers translated into Pela by Dom Tomás Gil were not frequently used or especially useful. I asked Dom Sanz to tell me the Lord's Prayer in Pela (of which he himself wrote a grammar and a dictionary, as we said above) and he said that he did not know it. Which means that first-hand catechetical instruction had not attained that level. The fact that the prayer in question was only achievable by those who knew quite a lot of English, and also that English was preferred to the vernacular language against the requirements of the Church (to be implemented whenever possible), is definitely revealing about the situation.

${ }^{24}$ By contrast, sedentarisation was associated with a number of conditions, such as leprosy and worms, against which nomadism implied a certain immunisation. Not every possible hygienic practice was observed in sedentary life. 
to designate things that their ancestors never knew existed. Any language needs to resort to loan words from other languages to create neologisms, but a limit must be established if one wants to preserve the purity of the former.' And, naturally, drawing a border between Pela and English was not feasible.

An example of this was Aborigines' attitude towards dogs, which never changed when they were Christianised. Dogs were part of their family, like human beings ${ }^{25}$, treated as equals in funerals and burials. One of the missionaries wrote that some Aborigines thought that dogs were regressively incarnated gods.

Dom Sanz did not restrain himself in his defence of acculturation: 'In my opinion, the decline in the number of old Aborigines, which was the missionaries' greatest sorrow $^{26}$, was a blessing in disguise, as the absence of those Aborigines made it possible to create among the youth the most detribalised, most Christian and purest native community in Australia.'

One of the accusations that are now being made against Australian governments is that they stole Aboriginal children from their families, placing them under the tutelage of institutions suitable to educate them in a white environment so that anything about the native culture that was incompatible with the new country would, in time, be absorbed by the dominant culture. Dom Sanz denied that this was the case of his mission, as only the children of the Aborigines who freely offered them to the mission stayed there. Also, the parents themselves lived around the mission ${ }^{27}$ and, accustomed to giving away their daughters for marriage to old men when the girls were eight to ten years old, could certainly not see the new situation as a worse one. As to the right of marriage between first cousins, which would have been incompatible with such new situation, these marriages could simply not be performed any longer owing to a lack of births.

\footnotetext{
${ }^{25}$ Still, we should not forget that the current pontiff is in favour of extending the palingenesis of Pauline resurrection to all living creation. This belief was already entertained by certain Catholic theologians, and personally taught by Martin Luther.

${ }^{26}$ One of them spent 53 years in the mission, and another one 45; a total of five died and are buried there.

27 They had lived in the mission since as early as 1962; there were common bedrooms at first, which were later closed by Dom Sanz. He confessed that he regretted having introduced this measure, as parents would not correct their children because of it; such correction was unknown among their own cultural values. The parent-child relationship, which did not involve correcting the child, was called mámangal.
} 
Naturally, the issue of the stealing of children and the responsibility of the different Churches in it are not among the topics of our discussion, as this account is limited to the Spanish Benedictine mission. One should bear in mind, of course, that the missionary intent was the Christianisation of the pagan population, which the missionaries saw as the greatest good. Could this perception have clouded the religious' judgement? Were they free to decide? Might they have seen it as a lesser evil to accept the government's suggestions? We will not go beyond putting forward these questions. In any event, the belief that politicians try abusively to offload their responsibilities onto ecclesiastic men $^{28}$, to the detriment of the objectivity of the approaches adopted, is rather widespread in Australian public opinion ${ }^{29}$.

It was only from 1955 that the natives were sent to school at the mission regularly and steadily, with a qualified teacher, when their population density made such schooling possible. Certain data relating to their results are revealing to cultural comparativists, at the intersection between ancestral heritage and the encounter with a new world. Mathematics were the main obstacle. For only the first three numbers and the generic 'many', djama, were known in the natives' language. Consequently, they also had difficulty understanding the notion of

${ }^{28}$ Cf. Human Rights and Equal Opportunity Commission (1997): Bringing Them Home: A Guide to the Findings and Recommendations of the National Inquiry into the Separation of Aboriginal and Torres Strait Islander Children from Their Families, and the private, multiple-author book (coord.: Carmel Bird) The Stolen Children: Their Stories (Sydney, 1998).

${ }^{29}$ We should not rule out the potential interference caused by interests to be vested, rather than vested interests, on the distant horizon. For example, a governmental committee - from the Commonwealth, State and Regions Department of Aboriginal Affairs - turned up in Kalumburu, accompanied by the abbot of New Norcia, to conduct a survey on the natives' acceptance of the right to a certain amount of land. In other words, an official preview of the claims that natives from many parts of Australia later filed profusely with the courts. The natives were offered 800,000 acres in Carson. They rejected them on the first day; they gave their assent on the second, but soon told Dom Sanz that they had been forced to do it. This suggests some insistent persuasion indeed, without resort to violence. However, the argument used was, above all, the possibility to designate a manager or administrator of the land, who could be replaced by a different one as many times as necessary in the event that he did not live up to his task. To make a generic assessment of the natives' answers, one should bear in mind that a characteristic of their culture was to consider that the person who had spoken first was right, except in cases of open fight. This explains such fantastic interviews as to make up cases of cannibalism: BROwN, Karen, 'Hunger Led to Cannibalism. Trek Survivor: Mr. Djángara endured a forced trek, falling bombs and a stockman's life before settling at Kalumburu', West Australia, 8-10-1994. 
'half. By contrast, they made unforeseen progress in English ${ }^{30}$ and good manners.

The environment of their religious education was identical to that of the pious families of the time. But it was precisely for this reason that differences between certain behaviours were more significant, and suggestive of how peculiar the assimilation of the natives had been. What they liked the most and best understood were biblical histories. When one of the old female students had a baby, she wanted to name him Cain. For this character, although evil, had been victorious. When the natives were asked about the meaning of the 'blessed fruit of thy womb' in the Hail Mary, some said it was a pear, while some others chose an apple. When they prayed to their guardian angels in the morning, Dom Sanz failed to understand a specific word that he thought had been sprinkled in, and which he therefore attributed to their language: túrrulangay. But it was their way, a truly mysterious one, of pronouncing the petition 'to rule and to guide', which they, of course, did not understand either.

Even if it seems strange, they were less ready for practical tasks. They were usually unable to take a step beyond the mere execution of orders ${ }^{31}$. A small shop was installed at a corner of the school with the exclusive purpose of teaching them to buy things and handle money. The exceptions can be seen as a preview of a distant future, rather than as such exceptions, but, of course, paying the painful price of acculturation described above; this was, for example, the case of a worker based in the Kimberley ${ }^{32}$ Research Station, in Kununurra, who came to be 'the picture of a gentleman'. In any event, being isolated in schools for whites was unbearable to the natives and, eventually, totally negative.

What they proved to be easily capable of was not only helping with Latin mass but also singing it, and not only in Gregorian chant but even with

\footnotetext{
30 There came to be a good typist among them.

31 Although Dom Sanz eventually attributed this lack of progress to 'the interference of civil authorities, and even philanthropists, who did not know Aborigines or their needs and capacities, as well as the contact with whites (especially since the 150-mile Gibb River Road to Kalumburu was built), with lax morals and sophisticated lives.' The latter cause had ruined the Anglican Forrest River Mission in 1965, and eventually turned out to be incompatible with any other mission in the Australian continent. Greed and suicide had been unknown among the natives before, but were not uncommon afterwards.

32 Another missionary's account: Francis Byrne, OSB (1989): A Hard Road: Brother Frank Nissl, 18881980: A Life of Service to the Aborigines of the Kimberleys, Nedlands, Tara House.
} 
polyphony. This was the case, during the Christmas after the Japanese bombardment, of the polyphonic composition created by an eminent musician from Navarre living in New Norcia, Esteban Moreno, which was accompanied on the accordion since the harmonium had been destroyed during that dismal bombardment. But it was a RAF officer who acted as an acolyte for Dom Sanz this time.

In this state of things, the Australian magazine Panorama published in 1960 a report on Kimberley whose title described it as a happy community. True: this adjective reflected an objective situation - but also the author's scale of values. This situation remained until 1967, when the natives gained the status of Australian citizens and so became beneficiaries of the social security, which granted them very generous unemployment benefits. It was initially agreed to allocate part of all the money received to the mission in exchange for its services $^{33}$. Naturally, some soon asked for the payments to be made individually ${ }^{34}$. But the most serious consequences of this situation were greed, gaming and drunkenness, which were the immediate results of the excessive availability of money, as the subsidies far exceeded the needs that this way of life involved.

Therefore, the independence of all Australian Aborigines of the tutelage systems previously in force came to be an overwhelming reality by virtue of what is sometimes called, not totally hyperbolically, vilis pecunia. And so Kalumburu eventually became an exception that shocked politicians, lawyers and anthropologists alike, but also the World Council of Churches ${ }^{35}$ and, most decisively, the Catholic hierarchy itself, i.e., the same body that had encouraged the foundation of the Kalumburu mission in 1908. This does not mean that the unrest had not taken hold inside the mission; in fact, two natives were the proof that this was the case, and the situation even made headlines ${ }^{36}$.

Some made the accusation that Aborigines had been deprived of freedom. The Australian bishops gathered in Sydney and the abbot of New Norcia

\footnotetext{
33 The accusation that Aborigines were simply working for the missionaries was not accurate.

${ }^{34}$ A symptomatic drawback: one had to prove that he or she had not worked in the previous two weeks to receive unemployment benefits, but the mission's postal service worked on a monthly basis only.

35 The Catholic Church was not represented in it at that time.

${ }^{36}$ In the Daily News, 24-6-1981; Peter Yu (born of Aboriginal and Chinese parents), in the Kimberley Land Council Newsletter.
} 
himself were unable to bear the pressure. The abbot resigned from his position of nullius administrator of the territory in 1980. In the following year, the Holy See simply supressed this exempt jurisdiction, which was therefore incorporated ordinarily into the Diocese of Broome. As a result, Benedictines would be able to stay there only through an agreement with the bishop. On 16 September, Dom Sanz left, having written in the visit book: 'Recedant vetera, nova sint omnia'37. We will recapitulate these points by going back to the southwest, where their origins are to be found.

\section{THE IDEALS IN THEIR CIRCUMSTANCE}

We have already seen how the two Spanish founders of the Benedictine community in Australia, Serra and Salvado, eventually grew apart over their insolubly different plans, which made Serra distance himself from Salvado. Serra wanted to consolidate a monastery in the style of those dating from European and North American Restoration, which would be possible only if they put the Catholic population of white colonisers first. Salvado was divinely obsessed with providing care to the native population, in painful decline. The fact that Christian love was his motive and inspiration is beyond question. However, Serra cannot simply be condemned just because, either, as if he only had had the desire of a comfortable, prosperous life on his horizon. For once one had adapted to the indigenous world - a certainly hard and even rather heroic deed - the gratification resulting from it could be more generous than anything that came from quite a poor population, which comprised mainly economically and socially weak Irish people then.

At this time in the history clock, even if this is historiographically heterodox, may we ask to be allowed to look back with the benefit of hindsight. The changes that the world has experienced since the mid- $19^{\text {th }}$ century could have never been conceived by any of our ancestors, not even those with the wildest

\footnotetext{
${ }^{37} \mathrm{He}$ wrote in his book that he had a copy of a detailed study on the end of the Benedictine mission, but that it is confidential. Recently, and almost unanimously, Kalumburu natives wrote to the abbot asking him to return.
} 
imagination. Still, the prodigy of technique and the agitation caused by the change of regime made it possible already to catch a glimpse of certain novelties able to make minds lose their restraint. This explains the hopes entertained in the context of European expansion by Benedictinism, which was rising from its own ashes: the ashes of the almost complete seizure of their assets and the forced dispersion of its communities. Dom Bonifaz Wimmer, a Bavarian who established a foundation in Pennsylvania, came to imagine the resurrection of mediaeval Europe, that of monastic missions among Germanic peoples, in those United States whose shape was not within sight yet. And, at the other end of Australia, John Bede Polding, the first archbishop of Sydney, tried to make its brand-new cathedral the reincarnation of the monastic cathedrals of old England, treating the chapter and the monastery as one and the same thing ${ }^{38}$. In this state of things, Salvado's Aboriginal dream does not seem so strange to us. Perhaps Serra's mind was, by contrast, more strongly anchored in the inescapable circumstances experienced in the field ${ }^{39}$. But the truth is that not a single native has managed to become a Benedictine monk so far - and it does not look as if more hopeful prospects were on the horizon.

When Kalumburu was called into question, some attempts were made to compare it with Salvado's New Norcia with the intent of making a negative assessment of his work ${ }^{40}$. This triggered Dom Sanz's reply, who put forward some very simple data. New Norcia enjoys a Mediterranean climate, and it always had everything that the white colonisation could offer just a few dozen kilometres away. Additionally, these colonisers were already in the surroundings; we have already said this. By contrast, the northern mission was isolated in a harsh tropical climate, as we have already described in considerable detail. Just one fact: when Salvado arrived, a dictionary of the local language had already been published; in Kalumburu, it was Dom Gil, the superior who died during the Japanese bombardment, and Dom Sanz himself who had to carry out such

\footnotetext{
${ }^{38}$ An example of this other side - cultural luxury - can be found in the article by Frank Carleton (1999) 'In Quest of Lamspringe Books', Tjurunga, 57 (11), 75-84 (previously in Biblionews, 23-4 [December 1998], 118-34).

${ }^{39}$ Serra's term was decisive for the emergence of the Subiaco settlement, in the vicinity of Perth; Ken Spillman (1985): Identity Prized: A History of Subiaco, Nedlands, University of Western Australia Press.

${ }^{40}$ Zoltan Kovals, in Weekend Australia, on the occasion of the sesquicentenary of New Norcia.
} 
a task personally and from square one. Dom Sanz added that the native race was not endangered there.

A certain lack of realism, in the long term at least, in the project conceived by Salvado - a man who, we should not forget, contributed to the ethnological knowledge of his Aborigines - could be deduced from the very need to transfer the mission for Aborigines to the distant north, while New Norcia ended up mainly as a source of monastic irradiation and Catholic consolidation for the whites in the surroundings.

While his successor himself, Torres, did not hesitate to become a explorer so as to reconnoitre the north coast in search of the new site ${ }^{41}$, he decisively promoted the development of the New Norcia of the future by establishing its two colleges, St Ildephonsus and St Gertrude, for white children ${ }^{42}$ of either $\operatorname{sex}^{43}$. Its noble factories preserve different objects, images and texts that arouse melancholy for the hopes contained in the memory of those girls who were in the prime of life, and their companions. These are, in the end, memories of hopes realised, and were decisive in the coinage of New Norcia's developed landscape. For New Norcia came to be a great monastery, as those coeval Western monasteries that we have described, and it nevertheless does not evoke that architectural image ${ }^{44}$. Its appearance is that of a citadel with dispersed buildings; yes, the great monastery does exist, but it is subsumed into that image, and may even go, as we mentioned, a bit unnoticed. The monastery has a large library, as the monasteries of that time commonly did, but it is exceptionally luxurious, which was not at all common even in those palaces for the scholarly spirit; a reading room fully decorated with frescoes where a summa of literature, arts and sciences has been painted - a job by a Castilian Benedictine, Lesmes González - with florid Latin distiches written by Dom Román Ríos.

\footnotetext{
${ }^{41}$ Dom Sanz noted Professor Elkin's appreciation of a Kalumburu monk for the contribution to 'Oceania' made by the latter.

42 The orphanage for the few remaining Aboriginal children continued in operation, and some of the adults who had settled in the small houses that had been built around it back in Salvado's time stayed in them. ${ }^{43}$ We evoked this atmosphere in our short story 'El sepulvedano de Nueva Nursia', in El Adelantado de Segovia, 22-12-1999.

${ }^{44}$ We have the press article 'Una visita a Nueva Nursia', in Nova et Vetera, Zamora.
} 
And we are talking about an spiritual aristocracy phenomenon that crossed borders. Those great monasteries whose golden age linked the 1850s and the 1950 s are history now. First, the lack of vocations is even threatening the very subsistence of these monasteries ${ }^{45}$. And second, the ideals of Benedictinism are different today. They are embodied in simple, small communities attached to the land, which flourish in the environment of the Third World, a place where there is also some hope in terms of vocations.

And in today's New Norcia, the testimony preserved cum amore of a place that came to be this young country's heritage, both in reality and in dreams, is a perfect example of the vitality of history - of how the past continues living in the present. There is a hotel - a residence for boarders' parents in days of yore - whose vast tranquillity is seductive, but which, paradoxically, evokes a setting à la Agatha Christie on the horizon.

\footnotetext{
45 This is a universal occurrence, which came to be overwhelming when it was preceded by certain shocks. This was the case of New Norcia until the abbot of Prinknash's apostolic visit, which entailed the expulsion of eleven Australians and two Spaniards, and the prohibition that no more Spaniards should go there in the future. The community had been a Hispanic islet until not so long before, and the transition to an Australian community, certainly a much smaller one, was traumatic.
} 


\section{SALVADO'S ARCHIVES: A UNIQUE LEGACY \\ Peter Hocking}

Archivist for the New Norcia community

Doi: 10.17075/rsmaa.2016.en.006 


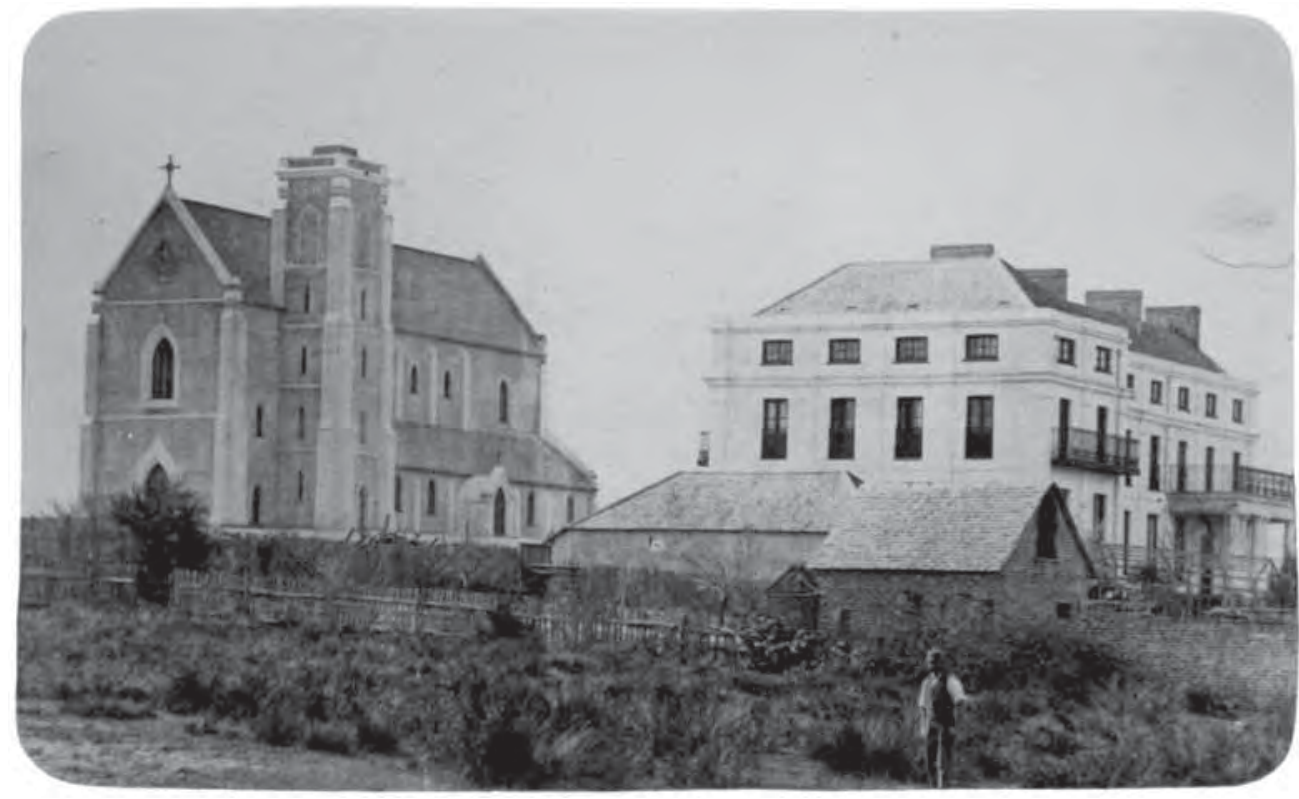


I am here today to talk about the legacy that Bishop Salvado left us - an exceedingly rich legacy which is possibly without parallel amongst private archives in Australia. However, this extraordinary legacy is not without its problems, and that is why I want to add a further subtitle - "unlocking the possibilities" - to my talk, but more of that later.

Firstly I would like to talk briefly about New Norcia, its establishment and its archives and then to explore what Salvado's legacy is.

I imagine that most people here today are are not familiar with New Norcia so I hope you will excuse me while I take a few minutes to set the scene.

The monastery was founded in 1846 by a group of Spanish Benedictine monks under the leadership of Bishops Rosendo Salvado and José Serra; their purpose was to set up a mission to civilise and convert the Aboriginal population of the Moore River to Christianity. The location they chose for the mission lies on a bend in the Moore River 140 kilometres north-east of Perth, the capital city of the state of Western Australia. Perth in 1846, though, was at the ends of the earth, on the very edge of civilisation, so you can imagine that another 140 kilometres further away, there was nothing: just endless vistas of woods and forests, undulating hills, scarce water resources, heat, flies, kangaroos, snakes and other dangerous wildlife.

For the next 50 years, under Bishop Salvado, the monks established and expanded their mission, set up a farm, educated the local indigenous population in farming practices amongst other things, and built a school for their children. Under the second abbot, Torres - who was an architect as well - expansion took place and a further school for the Aboriginal children was built, together with two very grand schools, St Gertrude's for fee-paying white girls in 1908, and St Ildephonsus - a similar institution for boys in 1913. Soon after, in 1927, the other grand building at New Norcia, the hotel, or hostel as it was then, was built to accommodate visiting parents. 
That second phase of New Norcia - education - came to a close in the early 1990 s and the monastery entered its third phase under the previous and sixth abbot, the late Placid Spearritt.

The monastery now exists to accommodate the nine remaining monks (from a peak of around 80 in 1900) who continue to practise the Rule of St Benedict. New Norcia is the only monastic town in Australia and it is also heritage listed so, somewhat naturally, missionary work and education have given way to tourism, which now plays the primary role, with some 70,000 people visiting the town each year.

Let us now turn our attention to the archives: the abbots were learned men; they were also prolific writers and photographers. As a result, we are blessed with a vast body of correspondence and numerous diaries written during the latter half of the $19^{\text {th }}$ century.

Bishop Salvado was held in such high regard that, after his death in 1900, his papers seem to have been dispersed under the beds of the monks for safe keeping for it was not until the 1950s and 1960s that a concerted effort was made by $\mathrm{Fr}$ Eugene Perez, a scholar monk, to pull together the huge quantity of material that had accumulated over the previous 100 years.

In the 1970s and 1980s, an arrangement with Perth's heritage library, the Battye, led to the micro-filming of the bulk of these historical documents. I should point out at this stage that the New Norcia archives are a private archives and therefore do not receive any automatic state funding.

The late Fr Placid arrived in 1983 and, under his direction, the archives became an entity managed by the monastery's first official archivist, Tony James. Fr Placid himself was a founding member of the Catholic Archives Group in England when he was at Ampleforth Monastery in Yorkshire; he, like Tony James, was a qualified librarian.

In 1984, a Lotteries Commission grant funded the establishment of a suite of rooms to house the archives. A second grant in 1986 made possible the indexing of the vast photograph collection. This huge task was undertaken at the Battye Library and was completed over the next two years by Wendy McKinley. At the end of 1988, Tony James moved on and Wendy took over as the logical successor. 
With Wendy as the new archivist, the archives expanded into five rooms; Compactus shelving was introduced and proper archival practice commenced. Computers arrived and soon the bulk of the collection was on a database. Wendy retired at the end of 2007 keen to see the archives move to the next phase - digitisation - which I inherited.

So what do these archives hold? During the six and a half years that I have been archivist at New Norcia, it has become more and more obvious that we, in effect, have two separate and distinct archives. One of them comprises everything from Salvado's death to the present day but by far the most interesting and important are the documents from Salvado's era; they are completely different from the documents from the reigns of successive abbots. They are still documents, still diaries and correspondence, so what is it about Salvado's collection that makes them so different, so unique? This is a question that I have asked myself many times and the answer that keeps coming back to me more than anything else (and more often) is "completeness".

As I will outline in the next few minutes, everything to do with the running of a monastery in the second half of the nineteenth century is here: the maps, the diaries, the letters, the registers, the employment records, the financial ledgers. Some, but not all, are evident to varying degrees in the records of the later abbots. It is almost as though Bishop Salvado had just left the room - a monastic Marie Celeste, or ghost ship, if you will.

In contrast, the records from later abbots are much more bureaucratic; in 1905, the government introduced an act called the Native Welfare Act which essentially removed indigenous children from their families and placed them in institutions so that they could be cared for and educated. Prior to 1905, children had been placed at New Norcia voluntarily by their parents, many of whom worked at the mission anyway. After 1905, this was not the case and New Norcia effectively became an unwilling agent of the government. This seems to have brought about a significant change in what we might call the "tone" of the records, which increasingly become less compassionate but more bureaucratic.

Looking back then at Salvado's records, we see a society that intermingled with the Aborigines and treated them like family, in stark contrast to what followed, particularly from 1905 onwards. I mentioned earlier that Bishop 
Torres, who followed Salvado, was an architect - it was he who also built the walls to keep the indigenous community and the monastic community separated. Little wonder then that the tone of the records changes as, clearly, the attitudes had changed.

So, if we concentrate only on the Salvado era, we have a collection of documents and photographs spanning 54 years, from the time the monastery was established in 1847 to Salvado's death in Rome in December 1900. What does it include and why is it so important?

Importance of course is relative in this collection - for one reason or another, every piece of paper is important because it is a witness to, or a record of, the great themes in Australian history. Australia was claimed by the British in 1788, the Swan River Colony (now the state of Western Australia) was founded 43 years later, in 1829, and the monastery only 18 years later than that, in 1847 , so it can be seen that New Norcia was in existence almost from the start of the Swan River Colony and not really that long after Australia was claimed by Captain Cook.

As a result, these great themes of Western Australian, and very often Australian, history are to be found in the registers, diaries, letters and records of Bishop Salvado - themes that cover agriculture, immigration, settlement, education, religion and interaction between settlers and indigenous peoples. And, uniquely, importantly, this story is told from a European point of view, not from the traditional Anglo-Irish.

Amongst the Registers are those which cover births, confirmations, marriages, deaths, and burials for New Norcia and its surrounding parishes, of which the baptism, marriage and burial registers have so far been digitised. Some of these have been microfilmed by the Church of the Latter Day Saints, which has made searching for individuals much quicker. A surprising consequence of Salvado's single-mindedness with regard to records is that Aboriginal families who grew up in and around New Norcia now have a wonderful family history database resource which goes back well over 100 years. It must be remembered that, prior to Salvado's arrival, the Aboriginal community had no written records, only an oral history tradition.

Farm records and registers for crops, horses, land, sale of produce, livestock, even weather conditions such as temperature and rainfall, have all been recorded. 
Additionally, there is a very valuable and extensive map collection consisting of over 300 maps and diagrams, together with manuscript maps of the local area dating from 1863. These show that, at its peak in the 1880s, Salvado's land holdings comprised nearly a million acres, which in modern metric terms is the equivalent of 4,000 square kilometres, or just slightly smaller than the land mass of the Balearic Islands.

And, just to summarise the remaining facets of Salvado's records before I turn to the most important documents, we have accounts for the monastery farm, the building and running of the monastery and, later, the schools, as well as pay sheets and records for the workers.

Also to be found are land records which, in addition to the maps, include diagrams, leases and agreements with workmen. There are also building records, water and sewerage plans together with floor plans.

Bishop Salvado was also a very good musician and pianist, famous for an impromptu concert he gave in Perth to raise funds. Music was an important part of life at the monastery throughout its history, even if it is only Salvado's concert, together with the Aboriginal boys' brass band of the late 1940s, which most people remember. There is a separately housed music archive (located within the main part of the monastery) devoted to the storage of music collected, and created, by monks at the monastery. Salvado's music has attracted considerable interest in recent months, as might be expected, and recordings of music not heard for many years have just been made.

We also have a substantial photograph collection. It is estimated that the collection has about 60,000 photos, many of them dating from the early days, including two daguerreotypes, one of Bishop Salvado, the other of his brother Santos. Indeed it was Santos, Queen Isabella II's chaplain, who introduced the camera to New Norcia in 1867; since then, the monks have been camera-happy. There are photographs of every building from every conceivable angle at every conceivable moment of the day, month and year, thus providing an extraordinary history of the development of the buildings and the town for the last 140 years. We have scanned about 20,000 of these photographs so far and, although they are not to be found on any online site, many of the Salvado era photos have since appeared in newspaper articles, magazines and books and one has even been used by the Australian postal service. An exhibition later in the year at the 
Western Australian State Library will exhibit the photographs from Bishop Salvado's time.

But the two areas which I consider to be the most important are the letters and the diaries. It is in these media that the real life of the mission and its interaction with the Swan River Colony can be experienced. It is here that the hopes and fears of $19^{\text {th }}$-century Western Australia are acted out, together with all the mundane details of daily life, as well as the surprising twists of history, and the happy and the sad, and often tragic, moments.

It is estimated that there are close to 20,000 items of correspondence in the archives - not all of this comes from Salvado's time but a disproportionately large amount does originate with Salvado. Amongst the correspondents are European royalty (particularly Queen Isabella II of Spain), Church and Vatican officials and the Colonial Office in London, whilst Western Australia correspondents included the explorer and Governor Sir John Forrest, as well as Governor Weld and well-known personalities such as Daisy Bates, who was a famous, often controversial but always eccentric Australian lady anthropologist of the late $19^{\text {th }}$ century. The famous English nurse Florence Nightingale even sought advice from Bishop Salvado, so surprised and impressed was she at the extraordinary state of health to be found amongst the monks and the Aboriginal population. There is also a substantial body of correspondence from "ordinary" people, for example shepherds, sawyers, shearers, neighbours, businessmen, right through the social spectrum down to humble workmen.

Additionally, there are important collections of letters, such as a substantial 250-plus body of correspondence from Canon Raffaele Martelli, an Italian priest who accompanied Bishop Salvado to Western Australia in 1853 and who later became the parish priest at Toodyay, a small town to the east of New Norcia, and also at Fremantle, the port city for Perth. We have a similarly large collection of letters from a French monk, Léandre Fonteinne, who, with Irishman John Gorman, accompanied Salvado on his very first expedition to the Moore River in 1846, where one rainy night he accidentally shot and killed Gorman while cleaning his gun. The event obviously had a profound effect on Fonteinne's sanity as he subsequently returned to France, a broken man, from where he wrote long, rambling, often incoherent letters to Abbot Guéranger at Solesmes, near Paris, for many years to come. There is also the correspondence 
of Théophile Bérengier, the abbot of the Benedictine community in Marseille, whose collection is equally as large as the first two, if not larger, as we now have scans of Salvado's letters back to Bérengier, discovered at Ganagobie in 2002. These are but three examples of large collections of letters from significant people. All of these letters I have just mentioned have been scanned for academic purposes, which I shall speak about later.

Finally we come to the most fascinating and valuable of the archives' documents - the diaries. The diaries of New Norcia are a remarkable collection of documents; these diaries, or perhaps more accurately, chronicles, provide an almost continuous daily narrative of the history of New Norcia since its foundation in 1846. Salvado's diaries, written in a miniscule hand in many tiny volumes over a period of fifty years, are the most valuable documents the archives have, and they have been the subject of much research over many years.

Salvado's successor, Bishop Torres, was not the diarist that Salvado was but he clearly recognised the importance of keeping some sort of community history because he initiated The Community Diary or Chronicle - a diary of daily events - in 1901 and this diary continues unbroken to the present day but, alas, not written with a quill on parchment by candlelight but in Word on a Toshiba by electric light. Until the early 1950s, it was written in Spanish, thereafter in English. These, too, provide a fascinating insight into daily life, where even the most ordinary of details can be discovered. We know, for example, that in the 1930s and 1940s the monastery cars were an American Essex, a Chevrolet, a Pontiac and a Hudson, which had been the German consul's car up until 1939, when he was obliged to part company with it. By the 1960s, it was an Australian Holden.

Because these diaries are so important not only for the history of New Norcia but also for what else was happening in Western Australia and further afield, I would like to look a little deeper into some of the more important and see what they can reveal about life in the second half of the $19^{\text {th }}$ century.

Salvado kept a diary for over fifty years and his diaries are by far the most important, simply because of the huge time span they cover and because they were written by the Bishop himself. He was not always at New Norcia, as he was often in Europe raising funds and looking for new missionaries. Unwittingly, 
the other diarists, shown previously, Francisco Marsa, Manuel Beleda, and Joannes Garrido, filled in the gaps with their own diaries.

Salvado's diaries comprise 15 tiny volumes written in a microscopic hand; the language is, naturally, Spanish but other languages are to be found, including Latin, French, Italian, English and a smattering of Aboriginal words. His diaries were partially translated many years ago by Fr Eugene Perez but sadly, Fr Eugene had a reputation for being a bit of a revisionist when it comes to historical fact, so we can't take his translation as being entirely accurate.

However, in recent years, an extremely generous bequest has allowed us to have the diaries transcribed as a first step towards their eventual translation. For this talk, the examples I shall give are taken from the 1876 and 1877 diaries. Unlike Beleda and Garrido, Salvado's diaries have everything: stories, humour, compassion, and tragedy and, throughout, we are always aware of how the Bishop felt about whatever he was writing about. Take, for example, the illness and eventual death at the age of 32 from consumption of Helen Cuper, the first Aboriginal telegraphist, on $12^{\text {th }}$ January 1877 . Her slow decline over many weeks is faithfully and sympathetically recorded by Salvado and, towards the end, her plight starts to dominate his diary entries.

Some of his entries are even quite humorous: Sunday 27th August: A number of wild Aborigines came and started a corroboree before the bell went at 8pm, and they kept going and going and going. I went out to tell them that after the bell went for bed time, I didn't want any more noise [...] and they stopped for the rest of the night. It isn't difficult to see the humour in this - a group of young Aboriginal men all set for a really good night of partying only to have it cancelled by a grumpy old man who wants to go to bed!

His own, and other people's, health was a constant source of wonder and concern to him; poor Martin Griver, Bishop of Perth, was seriously ill in Fremantle for several weeks during July and August 1876 but, for those six weeks, Salvado was by Griver's bedside ministering to him whilst writing his diary, in which he described not only Griver's alarming symptoms but the extraordinary medication given to him. On $26^{\text {th }}$ of July for example, the poor man was woken up at at an ungodly hour to face the following: 4am beef soup, 6.00 medicine, 8.00 chocolate, 10.00 medicine, 11.00 beef soup, 11.45 laxative, $2 \mathrm{pm}$ medicine, 4.00 castor oil, 6.00 medicine, 7.00 beef soup, $10 \mathrm{pm}$ an egg, 
then finally at $11 \mathrm{pm}$ another laxative. It must have been a great incentive to get better, as eventually he did, in spite of Salvado's treatment.

Finally, pity poor Br Melito, who serves to illustrate that life was pretty harsh in the 1870s and his going mad was about as unimportant as getting the sheep washed: October $7^{\text {th }}$ : Another flock of sheep washed - the twelfth such. Br Melito is beginning to show signs of madness and, this afternoon, $\mathrm{Mr}$ Clinch's servants returned from taking the horses to Fremantle.

The next most important diary, The Marsa Diary, a single volume written in Spanish in the most beautiful hand, is as important as it is intriguing. It is important because it continues the narrative from 1849 through to 1853 exactly the years Salvado was away in Europe.

Brother Francisco Marsa, a printer, was one of the 39 priests and brothers who were recruited by Bishops Rosendo Salvado and José María Serra to come to Western Australia to build the monastery at New Norcia. Salvado was not able to return to Australia at that time - it was Bishop Serra who led the group back - so his account of their 85-day trip in the Ferrolana (an ex-Spanish warship) is covered in one sentence and the early work at New Norcia is glossed over in a few pages. Marsa, however, experienced first-hand the physical hardships involved in colonising the Victoria Plains, the locality in which New Norcia is situated, and he was a witness to the complicated ecclesiastical turmoil which rocked the early colony.

In great detail, Marsa covers the voyage to the colony, his arrival in Fremantle, the difficult journey to New Norcia and the work and the hardships involved in building the monastery, for example the weather and the lack of water; he also provides many comments and observations about the Aboriginals. Marsa's diary is important, therefore, because it is the only continuous first-hand account of this period.

But it is the story of how the diary came to be back at New Norcia that is so fascinating. Francisco Marsa was at New Norcia for only four years; in 1853 he left New Norcia and returned to Barcelona, where he became a diocesan priest.

150 years later his diary, in perfect condition, appeared in the stock list of a Barcelona antiquarian book dealer; a visiting American antiquarian dealer saw it, bought it and took it back to the United States; in due course, it appeared in his catalogue, which was sent out to all his customers. And one of his customers 
was a Californian wine merchant who just happened to be a Friend of New Norcia. Our Friend bought the diary and donated it to the monastery in 2005; prior to its discovery, its existence was completely unknown, though Marsa himself is mentioned a few times in later correspondence. So far, this diary remains untranslated but it appears to be written in the same narrative style as Salvado's. So, whilst Salvado attempted to fill in the missing years of his diary retrospectively, it will be interesting to read what Brother Marsa had to say as events unfolded before him.

As Marsa was departing in 1853, Manuel Beleda, our second contemporary diarist, arrived with the 1853 group of missionaries led by Salvado; his diary starts on Good Friday 1854 and continues through to October 1865, when he left the mission and went to work for James Clinch at nearby Berkshire Valley; the final entries are for November 1868. His diary, again a single volume but enclosed in a leather wallet, was translated some years ago by academic Judith Woodward, who also wrote a most interesting account of the man and his association with New Norcia in the 1994 edition of the New Norcia Studies Journal. Beleda's diary is not the continuous narrative that Salvado's diaries were; by contrast, Beleda's diary is brevity itself, to the point where many entries are meaningless. His entry for $3^{\text {rd }}$ December 1863 says, somewhat mysteriously: "They bled me". There is nothing in the entries either side to indicate who "they" might be or why he was bled.

Equally brief, his entry for $27^{\text {th }}$ January 1865 , the day he ceased to be a monk at New Norcia, is summed up with wonderful conciseness by "I left the Mission". Why he left, his diary gives no clue. Except that, towards the end of the diary, there are inexplicable gaps, indecipherable writing in an unknown language (possibly a dialect) and, against some days, no entry, just double lines with the letters TP. In her article mentioned earlier, Judith Woodward discusses discontent among the lay brothers in the monastery at the time and hypothesises that these inscriptions are possibly messages in code to himself through which, as Woodward puts it, "Beleda is venting his growing feelings of frustration" which, in turn, compelled him to move to Berkshire Valley.

The last of our contemporaries is Joannes Garrido, who was the prior at the mission until his death in 1868; his diary is also of importance as it covers the 
period when Salvado was again in Europe, 1868-1870. Garrido's diary has been translated too, again by Fr Eugene Perez.

Since we have Beleda's and Garrido's diaries overlapping, I thought it would be interesting to compare the respective entries for Beleda's departure on that fateful day in January 1865; we find that Garrido's entry for the $27^{\text {th }}$ goes some way to explaining Beleda's taciturn comment: Garrido wrote: About 9 am, $\mathrm{Br}$ Mauro Beleda left the Mission, going to Mr Clinch [...] He didn't say goodbye to anybody, but left a letter in which he expressed the motive for his departure. That is, as he says himself, to please all those who wanted him out of here. Safe trip and may God guard him and protect him.

Obviously Beleda was not a happy man, but was he malicious as well, one wonders? His diary shows no animosity but then it shows no personal feelings of any sort either. Personally, I doubt that he felt any malice towards the mission as his diary, over the next few years, demonstrated a desire to maintain links with the monastery, not break them. The fact that his diary was returned to the monastery after his death, according to his wishes, also suggests that Beleda harboured no ill-will.

At the beginning of this talk, I started by saying this extraordinary and unique legacy was not without its problems, and that was why I wished to subtitle this talk "unlocking the possibilities". Most of the correspondence and all the diaries are in Spanish, and that is the main problem - in fact Spanish remained the dominant language at the monastery until the mid-1950s, when the decision was made to make English the principal language, although by then it was really only the community chronicle that was still in Spanish. Apart from Dr de Castro, a Spanish academic and historian, and member of the archives' staff, who does a wonderful job for us in translating documents from Spanish to English, and the monastery's Fr David Barry, there are very few Spanish speakers in Western Australia, and the extent of the documentation is so great that it is far too much to expect Dr de Castro and Fr David to translate everything, to unlock everything, so that they might be available to English-speaking researchers.

In 1992, a committee, the Archives Research and Publications Committee, was appointed to look into how this huge body of material could be unlocked and made available. One result was the establishment of a Studies Day, held 
annually, at which people would present the results of research conducted in the archives; generally there would be four speakers. In its 22-year history, it has given rise to an amazing array of information gleaned from the archives covering an enormous range of topics, including Western Australian history, farming practices, Salvado's relations and interactions with the Aboriginal community, bee-keeping, biographies and so on and so on.

That, in turn, has generated the New Norcia Studies Journal, being the papers from the year's Studies Day - this year will be the $23^{\text {rd }}$ edition - as well as other papers that, for practical reasons, could not be delivered on the day. The Committee also oversees the publication of a variety of books - Salvado's Memoirs was the first, being an English translation of his 1851 Memorie, originally published in Rome; this is now in its $3^{\text {rd }}$ English edition. Other titles include $A$ Town Like No Other (being a look at different aspects of historical as well as contemporary New Norcia), Señor Pilich the Monastery Cat (an amusing look at life in the monastery from a cat's perspective), and The New Norcia Story, a history, now in its $10^{\text {th }}$ edition.

I mentioned earlier, too, that significant collections of correspondence had been scanned for academic purposes. Four years ago, the Italian Department of the University of Western Australia heard about Canon Martelli's letters, written over a thirty-year period. The Department was, and still is, interested in the development of Italian outside Italy during the $19^{\text {th }}$ century and our collection seemed like a good resource. We scanned the letters and these have now been transcribed and translated; in fact, so important was this collection that it now involves exchange students from the Catholic University in Milan, in Italy, working on them. Those four years have seen not only the transcription and translation but there has been enough scope in the analysis to provide material for at least three university degrees. An interesting result from the University's work is that it seems that Italian was far more prevalent in Western Australia than had previously been thought. The Martelli letters are due to be published at the end of the year.

The letters of Léandre Fonteinne have also been scanned, transcribed and translated and they too will be published with the Martelli letters in November. Théophile Bérengier's book, Histoire de la Nouvelle Nurcie, has been translated 
over the past four years and this is also due for publication at the same time, the first time it has appeared in English.

As you might imagine, all this scholarly work can be an expensive exercise, so we are most grateful for the extraordinarily generous bequest that has allowed us to transcribe the 800,000 words of Salvado's diaries. In 2008, the sixth abbot of New Norcia, Fr Placid Spearritt, passed away. He was a wonderful supporter of the archives and, for many years, he had dreamed that, upon retirement, he would learn Spanish and spend his remaining days in the archives.

Sadly, he passed away before this could be realised, so, in honour of his own scholarship and his dreams of furthering the research in the archives, a considerable sum of money was raised through very generous benefactors which now provides the basis for the annual Abbot Placid Spearritt Memorial Scholarship; from this, a stipendium is paid to a scholar to complete a particular area of research. So far, this scholarship has seen the completion of the letters of Martelli, Fonteinne and Bérengier, the translation of Bérengier's book, and the translation of Salvado's 300-page Report to Propaganda Fide in 1883; work currently in progress includes the translation of Salvado's letters to Bérengier, discovered at the monastery of Ganagobie in France in 2002, as well as research into the Italian origins of the engravings in Salvado's 1851 book, mentioned above. Much has been done to unlock these archives - but so much more remains.

In conclusion, I hope it can be appreciated from what has been said that the archives of New Norcia hold a uniquely valuable resource for those wishing to research the many and varied aspects of Western Australia's admittedly short history. In fact, so all-embracing are these documents that Dr De Castro concluded a paper she wrote in 2005 by stating that: No history of Western Australia is complete if it avoids using New Norcia's records [...] and nobody wants to write a lame history of Western Australia, do they? 



\section{POWER IN CONFLICT WITH THE ESSENCE OF PEOPLES}

Susan Ballyn

Founder and co-director of the Centre

d'Estudis Australians (Australian Studies Centre) Universitat de Barcelona

Doi:10.17075/rsmaa.2016.en.007 


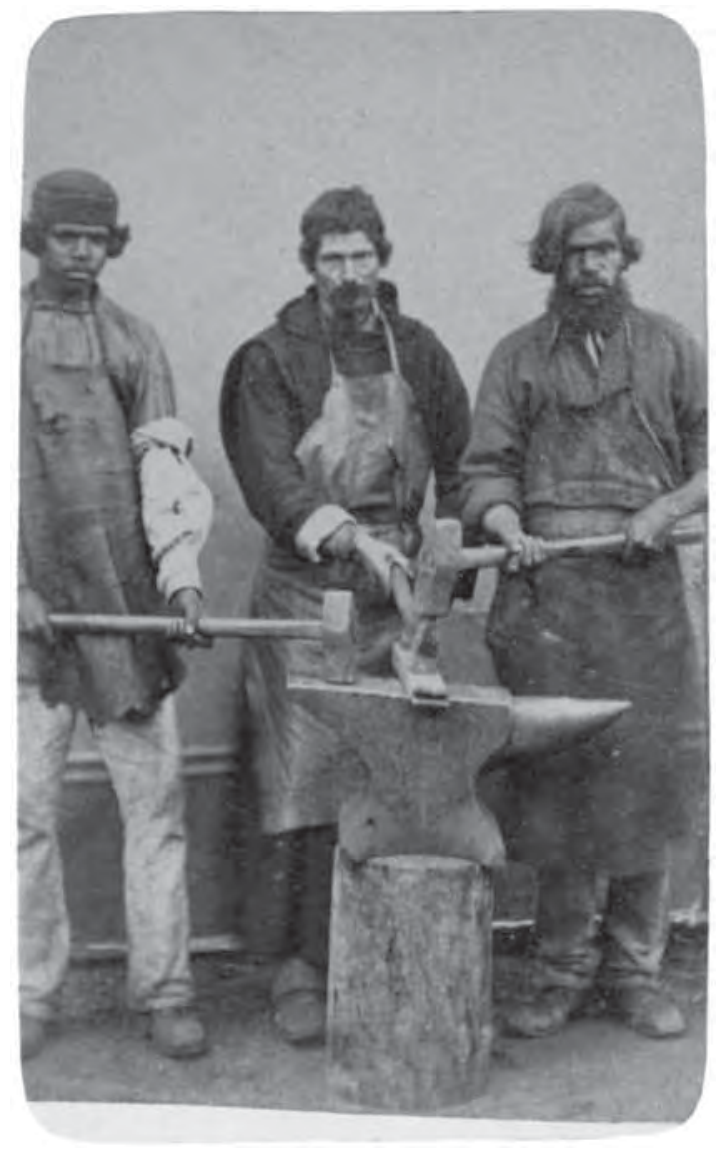


The declaration of Australia as terra nullius by the British paved the way for invasion and the systematic decimation of Indigenous cultures and lives. The Imperial Declaration that the land belonged to nobody was an excellent way of excluding any path to the recognition and rights of the Indigenous peoples. British power was exerted in the name of founding a new colony which would serve the Imperial purpose and allow for a civilizing process to take place for the "wretched" native peoples, who were regarded as the last rung in the chain of human evolution, a vestige of past peoples. The power of the British lay in their belief in the righteousness of their appropriation of the land, the judgement of the Indigenous peoples as almost unworthy of the name human and, of course, in their overwhelming numbers, their weapons and the speed of the colonial expansion.

The Indigenous cultures on the continent conceived of power in a totally different way which made them an easy prey for the invader. The land did not "belong" to them, they were the guardians of a land handed down to them over thousands of years by the ancestral creation spirits. The transmission of their culture was oral, but also explained in rock paintings and ceremonial rituals, music, songs, dances and body painting. Confronted by the powerful, materialistic invader hungry to make the land productive, as God had intended it to be, their culture, based on the power of ancestral law, did not stand a chance ${ }^{1}$.

Before approaching the subject of the cultural clash between the British invaders, colonisers and the Aboriginal peoples of Australia, I need first to centre on the figure of Rosendo Salvado, to whom this volume is dedicated on the bicentenary of his birth. Prof. Doireann MacDermott asked a pertinent question

\footnotetext{
${ }^{1}$ Author's note. I am not Aboriginal and wish to state first my recognition of the Aboriginal and Torres Strait islander peoples and their lands. In writing this article I stand to be rectified as my knowledge of Aboriginal culture can never be that of an Aboriginal him/herself.
} 
when she wondered if the history of Australia would have been different if the Spanish rather than the British had invaded the continent. I fear not as wherever Europeans have invaded "new" countries the story has been the same: the attempted extermination, if not of the natives themselves, then at least of their culture. It is for this reason that the figure of Rosendo Salvado stands out as unique regarding his attitude to natives, in this case the Aboriginal peoples of Australia.

Salvado believed that the only way to approach the "other" was through a full comprehension of their social-cultural convictions and of their language, without which it would be impossible to establish a mutual cultural exchange and respect. Far advanced for his times, the relevance of Salvado's work is diametrically opposed to the thought of his times, social Darwinism, and to the common belief that all Aboriginal peoples were just one rung above the animal and a dying race. One only needs to confront Salvado's views with those of Daisy Bates, who lived among the Aboriginal peoples for decades from 1899 onwards. Daisy Bates was an anthropologist and journalist, although she had no formal training in anthropology. As pointed out in the Australian Dictionary of Biography, "Her anthropology found little favour with anthropologists and her papers lay dormant for three decades, though latterly they have received some scholarly attention. The usefulness of the collection as a resource of anthropological information lies in the strong empirical thread in her research, coupled with a precocious manifestation of the anthropological method of living with one's subject" 2 . She fully believed that the Aboriginal race was moving into extinction and thus she wished to "smooth the pillow of a dying race"3. She abhorred the idea of mixed marriages and the resulting half-castes, as Bob Reece pointed out in his 2005 talk on her, quoting her remark "The only good half-caste is a dead half-caste" 4 . Charles Darwin commented in The Descent of Man, published in 1871, that "At some future period, not very distant as measured by centuries,

\footnotetext{
2 "Daisy Bates", Australian Dictionary of Biography, http://adb.anu.edu.au/biography/bates-daisy-may-83. Accessed February 2014.

3 The Independent, Tuesday, April 22, 2014, http://www.independent.co.uk/news/world/australasia/ the-great-white-queen-of-the-nevernever-790488.html.

${ }^{4}$ Bob Reece: "You would have loved her for her lore": The letters of Daisy Bates', Manning Clark House, Saturday, January 1, 2005, http://manningclark.org.au/papers/you-would-have-loved-her-her-lore-lettersdaisy-bates. Accessed February 2014.
} 
the civilised races of man will almost certainly exterminate, and replace, the savage races throughout the world" Salvado, on the other hand, was adamant in his belief that "no puedo convencerme de la teoría de que estos hombres sean incapaces de mejora, y que su extinción, a medida que vaya penetrando en el país la raza blanca, sea una necesidad insuperable"6. Salvado thus challenges Darwin and others like Daisy Bates and it is this confrontation of attitudes that clearly defines Salvado's far-sighted compassionate and un-patriarchal beliefs with regard to the Aboriginal peoples of Australia.

January 26, 1788 was a fatal day in the history of the Aboriginal peoples of Australia. That day the British invaded the continent and took possession of the land in the name of the Crown. In order to understand the cultural clashes that occurred between the invader, later colonisers, and the Aboriginal peoples, we need to understand something about their socio-cultural-spiritual paradigms and how diametrically opposed these were to those of the invader.

The Aboriginal belief system is based on the sacredness of the land and all living and inanimate things that form part of it. The creation of the world according to Aboriginal belief is called the Dream Time or the Dreaming but bears no relation to the Western meaning of the word. In the mists of time, before the world existed, ancestral spirits lay waiting beneath the surface of the land until such a time came when they erupted onto the surface and created all things on earth, both animate and inanimate. As they moved across the land they also created the stories that accompanied their creational experiences. Many of these stories contain both the norms by which Aboriginal peoples should live and also how they should relate to the land and to each other. Thus these stories become the core of sacred law to be passed down unaltered throughout time. "Once the ancestor spirits had created the world, they changed into trees, the stars, rocks, watering holes or other objects. These are the sacred places of Aboriginal culture and have special properties. Because the ancestors did not disappear at the end of the Dreaming, but remained in these sacred sites, the

\footnotetext{
5 C. Darwin: The Descent of Man, first posted: November 28, 1999, http://www.gutenberg.org/cache/ epub/2300/pg2300.html.

${ }^{6}$ R. Salvado: Memorias históricas sobre la Australia y particularmente acerca de la misión benedictina de Nueva Nursia y los usos y costumbres de los salvajes, Barcelona: [s.n.], Imprenta de los Herederos de la Viuda de Pla, 1853, p. 298.
} 
Dreaming is never-ending, linking the past and the present, the people and the land" 7 . As a result, every individual and group is inextricably linked to the land not as an owner or owners, but as a guardian or guardians who will ensure that the ancestral laws are implemented and that the social cohesion of the group both between each other and with the land will remain intact and secure. The concept of ownership of the land was totally incomprehensible to the Aboriginal peoples as their Spirit Ancestors had entrusted them with its guardianship to use with care and to abide by the ancestral sacred societal rules. Bill Neidjie, of the Gagudju people, neatly synthesises the relationship between Aboriginal peoples and the land: "I feel with my body. Feeling all these trees, all this country. When this blow you can feel it. Same for country [...] you feel it, you can look, but feeling $[\ldots]$ that make you $[\ldots]$. Our story is in the land $[\ldots]$ it is written in those sacred places [...] My children will look after those places, that's the law"8.

Like all oral cultures, the Aboriginal peoples developed various means by which the law and creation stories of the ancestral spirits could permeate down through thousands of years unaltered. The main way to communicate the wisdom of the ancestors lay in storytelling. This was not a rehash of stories that changed and mutated with each generation, quite the reverse. The creation stories and the laws by which the people should live came down verbatim, unchanged through the careful tuition of the elders to the younger members of the clan. No change was allowed and so the stories that Europeans first heard in languages unintelligible to them were none other than those that were sung by the ancestral spirits as they created the world. Stories are, as we know, transmitted in multiple ways and Aboriginal cultures are no exception. Rock, bark and body painting, sand painting, singing, dancing, carving on artifacts were all a means of transmission. Sand painting is a particularly good medium to use as an example. While the elders sat with the young ones they would draw in the sand and, as they did so, sing the story of their painting. Similarly, as they moved across the country they would sing, tell stories and dance around the fireside. Sacred places would have their meaning explained in words and rhythms that

\footnotetext{
7 "The Dreaming", http://australia.gov.au/about-australia/australian-story/dreaming. Accessed February 2014.

${ }^{8}$ Bill Neidjie with Stephen Davis and Allan Fox: Kakadu Man, Darwin, Resource Managers Pty. Ltd., 1965 , pp. 51, 65.
} 
never changed. Thus the children learnt the great creation stories and law and the continuity of the Aboriginal belief system and land was thus ensured.

It would be wrong to imagine that all the stories were open to all the community. Many of the ceremonies were open to all but there were those that could only be heard and performed by the initiated and were banned to those who were not. Others were women's stories alone and could only be retold among women, others were men's stories and punishment for infringement of the gender barrier would be swift for the culprit, often resulting in their being banished from their clan and thus left to wander soulless across the land of others'. Once exiled from the land that spiritually and physically nourished them, a lonely death was often the only release.

While all comparisons have areas of slippage in meaning, perhaps the only way in which the non-Aboriginal can understand the importance of the land for them is by looking upon it as a sacred text that also contains the precepts of law, a people's history and genealogy, both collective and personal, and an intricate and complete cartography. A complex cosmology carefully guarded by the group and the individual. The ecosystem on the continent was and still is a delicate environment in which everything lived in a precarious relationship with the rest. Any disturbance of that ecosystem could bring about the most devastating consequences, as has been witnessed by the increasing desertification of the continent since the arrival of the Europeans.

Before the invasion of the continent, the Aboriginal peoples led a nomadic life as hunters and gatherers. Like other hunter-gatherer peoples, the women harvested roots, honey and other edibles while the men hunted. Such was their knowledge of the land that they would move across it according to what was ready to be harvested or hunted in a particular area. As they moved, often hundreds of kilometers, they would "sing up" the land and perform the appropriate ceremonies at the various sacred sites on their way. The Aboriginals only took from the land as much as they needed to subsist, never exhausting any of its resources. They also engaged in what we call fire-stick farming. This entails a careful burning off of the scrub with two effects. Animals would run before the flames and could be easily hunted and the surface vegetation, once burned off, would soon yield new shoots on which the wild life could graze and grow. Everything the Aboriginals did in their relationship with the land was to ensure 
the continuous abundance produced by the environment. It is no wonder then that, as Salvado noted, they were surprised that the white man could not survive in the desert areas when they could always find food and water. Only a profound knowledge of the land and its cyclical variations could make this possible, something the white man had alienated himself from thousands of years ago, besides finding himself in a totally hostile environment.

Unlike the Maori of Aotearoa, New Zealand or the North American Indians, the Aboriginal peoples were not warriors in the full sense of the word. There had never been out-and-out wars between clans, but individual grudges often settled in single combat. Over the thousands of years they had lived on the land they had never had to defend it either against an invader or territorial clashes with other clans. This, unfortunately, led to the idea that the Aboriginals would not resist the European. Nothing further from the truth. Once they realised that the invader had no intention of sharing the land, nor of negotiation, but encroached further and further into their traditional lands, they soon learnt that attack and defence were the only viable ways to confront these outsiders. They were, however, ill equipped against the guns of both the military and the colonisers and thus mostly used guerrilla tactics, appearing out of nowhere, attacking and vanishing back into the bush. The superiority of numbers and weaponry and continued genocide, as we shall see later, were, however, to decimate their peoples and leave them on the edge of spiritual and physical exhaustion.

On invading Australia the British made use of two terminologies that began the process of invisibilising the Aboriginal peoples and nullifying their rights to their land. Australia was taken by the British using the term "terra nullius", loosely translatable as "land belonging to nobody", and in international law the term indicates land which has never been under the sovereignty of any state or people. Thus anybody who occupies the land can claim sovereignty over it. By making use of this law the British established from day one that, in terms of international law, the Aborigines did not exist and that they had no claim over the lands they occupied. The second terminology which further invisibilised the Aboriginal peoples was precisely "Aboriginal". If we consider that we are all Aboriginals from somewhere, calling the natives of Australia by that name was a deliberate attempt to, firstly, place all the natives into one basket with no recognition of difference between them and, secondly, to basically refer to them 
with a no-name. When the British occupied North America, although the general term "Indian" was used, each tribe became known by its own name; thus we have the Sioux, the Apache and so forth. Treatises, however dubious, were signed by the British and coloniser with particular tribes. In the case of Australia no treatise was ever signed because, as it was terra nullius, the natives had no rights. Thus began the first attempts to invisibilise and negate the existence of a people considered to be beyond the pale of civilisation and thus condemned to extinction. The question remains: how was it that the Aboriginal peoples began to die out so fast?

As with other invaded and colonised people, especially in North America and the Pacific, the Aboriginal peoples had no immune system that could counterattack such illnesses as smallpox, influenza, whooping cough and the whole gamut of other ailments the invader introduced. Thus there was a high death toll resulting from such illnesses. As the coloniser encroached upon Aboriginal lands they drove their inhabitants away from their traditional hunting grounds and sources of food. Apart from this physical aspect, it is well known that Aboriginal peoples removed from their lands became spiritually debilitated, depressed enough to die from sadness as a result of separation from the land they had held in custody and with which they had communed over thousands of years. This state of mind also lowered their immune system, further helping to raise the numbers of deaths from white illnesses. There were also fearful clashes between the colonisers and the Aboriginal peoples. In retaliation for the Aboriginal stealing of stock on which to survive, not only were the culprits hunted down and killed but very often various members of their community were murdered as well. Policing this kind of horror on the colonial frontier was difficult and, if the general appreciation of the natives was that they were on their way to extinction, then did a murder really matter or, worse still, a massacre?

By the end of the nineteenth century, it became clear that the Aboriginal peoples, though greatly decimated in numbers, were not going into extinction and they were now referred to as the Aboriginal problem, a clear signifier that they were still profoundly troubling to the colonisers. In 1905 a new process was to begin which, it was hoped, would really put an end to the presence of Aboriginal peoples in Australia: eugenics. 
Large numbers of Aboriginal peoples were already living in or near missions or reservations and it now became of paramount importance that they be totally controlled. Between 1804 and 1911 the various states and territories brought in Aboriginal protection acts that were designed to strictly control the movement and private lives of all Aboriginal peoples. They were unable to move freely around the continent without special passes, they had to have special permission to marry, which, as we will see, formed the core of the practice of eugenics, they were not allowed to speak their languages or carry out any of their ritual ceremonies. Anna Haebich points out,

The 1905 Act $^{9}$ controlled virtually every aspect of Aboriginal lives - with whom they could associate, where they could live and work, and their earnings, personal property, family life, marriage, and sexual contacts - and allowed for their removal to institutions where they could be detained indefinitely. Fines and imprisonment awaited those who dared not to comply with its provisions. Such was the virtually totalitarian control vested in the so-called Chief Protector of Aborigines ${ }^{10}$.

As is well known, the theory of eugenics is based upon the belief of a genetically superior race and that all inferior races can be bred out through carefully controlled marriages. This resulted in one of the darkest parts of Australian history. In order for the Aboriginal race to be bred out, it was necessary to separate full blood from any contact with half-castes. At the same time it was equally necessary that a half-blood Aborigine marry into whiter stock until eventually, in theory, the dark-skinned people would vanish. This theory, as we know, failed in practice because it did not take into account genetic throwbacks or the fallibility of a superior race. In order to implement the practice of controlling the descendents of Aboriginal peoples, those who were half-caste, quarter-caste, octoroons, etc., were separated from their families and taken far away from where the relatives remained in order to break all contact

\footnotetext{
9 This refers to the 1905 Western Australian Aborigines Act, which would include in its mandate New Norcia.

${ }^{10}$ Anna Haebich: "“Clearing the Wheat Belt": Erasing the Indigenous Presence in the Southwest of Western Australia', in Dirk Moses, ed., Genocide and Settler Society, New York, Berghahn Books, 2004, p. 272.
} 
with them. From 1905 until the very early 70s, thousands of children were taken away from their parents and put into missions and orphanages or, if very blond, fostered out to white families. These children became known as the "Stolen Generations", though the exact numbers taken away will never be known. Once in the missions they were indoctrinated into the Western culture. Forbidden to speak their languages or to search for their relatives, these youngsters were destined to be domestic workers or farm workers and to be fully assimilated into white society.

Rosendo Salvado would have been horrified if he had known what was to happen, but he too, like Fulgencio Torres and Anselm M. Catalan, his successors as Abbotts of New Norcia, would have had no choice but to obey the orders of the state if the mission were to survive. As a result, children who had been kidnapped from their families were interned in New Norcia together with a number of other settlements in Western Australia such as the Moore River Native Settlement.

It is difficult to imagine the accumulative traumatic effect that this constant separation of families could possibly produce both then and decades later.

The twentieth century saw the continuance of the assimilationist policy legislated in 1937. The minutes of the Aboriginal Welfare Conference of Commonwealth and State Authorities, which met in April 1937, clearly reveal the policy to be followed and the clear attempt to finally destroy Aboriginal culture: "The destiny of the natives of aboriginal origin, but not of the full blood, lies in their ultimate absorption [...] with a view to their taking their place in the white community on an equal footing with the whites" 11 . The legislation reinforced segregationist policies with separate areas in hospitals, schools refusing to enrol children and a whole host of other segregation criteria. It was not until 1967 that a Commonwealth referendum would be held to determine if Aboriginal peoples were to be given Australian citizenship and be included on the census. A landslide victory was supported by $97 \%$ of the voters and hopes now began to rise among the Aboriginal communities and those non-Aboriginal people who supported them that things would change. They would, but very slowly.

\footnotetext{
11 "Aboriginal history timeline (1900-1969)", http://www.creativespirits.info/aboriginalculture/history/ aboriginal-history-timeline-1900-1969. Accessed February 2014.
} 
The struggle for land rights, equal opportunities, the attempt to end discrimination and for an improvement in the quality of life for Aboriginal peoples was to continue throughout the twentieth century and even today.

1992 was an outstandingly important year in this respect. Eddie Mabo, a land right activist, together with David Passi and James Rice, among others, claimed the rights of their people to native title over Murray Islands in the Torres Strait. In many senses this was a test case to determine the legal land rights of the Meriam people and, by extension, all Aboriginal peoples. The legal battle began in 1982 with Mabo always in the front line. Ten years later and five months after Mabo's death, the High Court delivered a stunning verdict. On June 3, 1992, the High Court ruled by a six to one majority vote that the Meriam people held native title over the islands and overturned the use of "terra nullius", thereby recognising that the continent had never been an unoccupied land. Thus, over the following decades the successive governments would develop the Native Title Act, first legislated in 1993. It goes without saying that the Mabo case and verdict was to cause division in public opinion and, similarly, not all governments in power were to agree on how to proceed with the Native Title Act. There was, however, a slow but forward movement with regard to native title and also with regard to the discrimination to which Aboriginal peoples had been and are subjected.

The next landmark was to come with the national enquiry into the Stolen Generations, a seven-hundred-page document, tabled in the Federal Parliament on May 26, 1997. The report brought the people of Australia up short with its declaration that the removal of Aboriginal children by force was an act of genocide and thus against the United Nations Convention on Genocide, ratified by Australia in 1949. The document brought innumerable witnesses' stories and clear evidence of the breach in the UNCG into the public sphere both as the subject of national debate and discussion point among the Australian population itself. In spite of Prime Minister John Howard's refusal to apologise to the Aboriginal peoples, one year after the publication of the report there was a massive response by Australians during the first Sorry Day, with marches across the nation significantly over bridges as a symbol of the need for reconciliation. It was not until February 13, 2008 that a public apology came offered by the then Prime Minister Kevin Rudd. 
The issues surrounding land rights and equality in all areas of life for Aboriginal peoples are still unfolding, exasperatingly slowly for some. One has to hope that eventually reconciliation will bear fruit at all levels. The situation is complex to a degree and progress can only be made if all sides involved can find ways in which they can work together towards a satisfactory outcome for all. One can not but help asking oneself what Rosendo Salvado would have said and done in the present situation. Throughout his life and work in Western Australia, Salvado had always insisted on the importance of respect for both the natives and their traditions. Respect for one's fellow human being was the cornerstone of his work with the native peoples of Western Australia. I personally believe that today he would advise that, first and foremost, any discussion of any kind, political or domestic, must be initiated on the equality that derives from mutual respect: for the "Other" is none other than oneself. 

BISHOP ROSENDO SALVADO'S VISION OF ABORIGINAL MISSION WORK IN

THE VICTORIA PLAINS

OF THE COLONY OF WESTERN AUSTRALIA

Anna Haebich

John Curtin Distinguished Professor

Curtin University (Western Australia)

Doi:10.17075/rsmaa.2016.en.008 


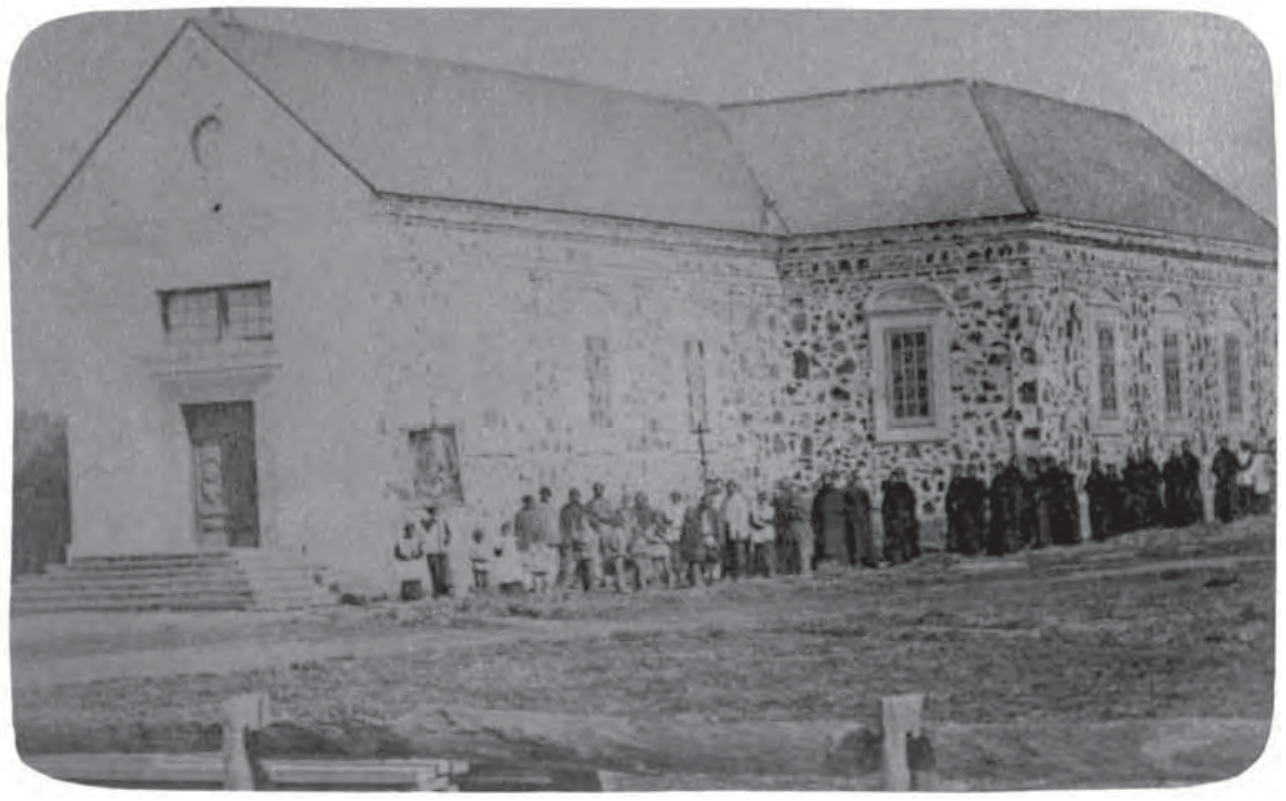


Rosendo Salvado was one of thousands of missionaries swept up in the great missionising drive of British and European colonial empires during the nineteenth century. However, he is one of only a few whose memory is still honoured today.

In the early decades of the nineteenth century governments, churches and humanitarians seeking to temper the human destruction wrought by colonisation on Indigenous populations looked to missionaries to spearhead a process of benevolent change. The recommendations of the 1837 Select Committee of the House of Commons, known as the Buxton Report, set out the strategy for 'Christianising and civilising' Indigenous peoples to become British subjects and concluded that 'every tribe of mankind is accessible to this remedial process' (British Parliament: House of Commons 1838, p. 44). However, many settler colonists in Australia were no longer convinced of such achievements and emerging theories of race, evolution and social Darwinism reinforced their pessimism over the nineteenth century. Transnational humanitarian optimism and settler colonist pessimism framed the development of Salvado's idiosyncratic vision of missionizing, which was judged as enlightened and compassionate for its times and a showcase of charitable reform. Yet, like other missionaries Salvado's philanthropy inevitably became enmeshed in the dynamics of colonial dispossession and loss with repercussions that resonate into the present. This paper addresses Salvado's life work through the fractured lens of competing and clashing forces that enabled and challenged his determination to achieve his vision in the distant outpost of the Swan River Colony on the west coast of Australia.

Salvado dedicated his life to the Church. Born in Tui, in Galicia, Spain in 1814 into an educated and musical family, he entered the Benedictine Abbey of St Martin of Compostela at the age of fifteen, where he was the organist and studied philosophy and the liberal arts until he went into exile in Italy in 1838 
following Spain's 1835 anti-clerical revolution. He was ordained as a priest in 1839 and 'his great epic' in the Australian colonies began to take shape (William 1967, p. 1). The Bishop of Sydney and English Benedictine, John Bede Polding, proposed that Salvado join him in Sydney but a meeting in Rome with the Bishop of Perth, John Brady, decided his vocation to work with Aboriginal people in Western Australia. Pope Gregory XVI, also part of the Benedictine monastic family, farewelled Salvado and fellow missionary Joseph Serra with this reminder of the order's great missionary tradition:

[...] remember you are sons of St Benedict, our great founder. Remember all those Apostles who were your brothers, who converted whole peoples and nations to the faith, and educated them in the ways of civilized life. Remember that you are setting out on the same road as was trodden by them. (Cited in Russo 1980, p. 21)

The men sailed with Bishop Brady and arrived at the Swan River Colony in January 1846. Their prospects in the colony seemed grim. Founded in 1829, this was a struggling colonial outpost of British Protestant settlers attuned to the antagonisms of nationality and religion. Support for Aboriginal missions had flagged in the colony after they failed to turn out useful workers to relieve the disastrous labour shortages plaguing the colony. A likely powerful ally, Governor Hutt, known for his philanthropic efforts to protect, educate, train and reform Aborigines, left the colony the month after Salvado and Serra arrived. Governor Fitzgerald, who arrived in 1847, was preoccupied with the introduction of convict transportation in 1850 to solve the labour crisis. Outside the colony, the Church hierarchy in Sydney, led by Bishop Polding, welcomed its fellow Benedictines and Salvado could always find a sympathetic ear in Rome. However, the local parish, of predominantly Irish working class families, had little interest in Spanish monks and the fledgling Catholic diocese was without political influence or money. The only other Catholic missionaries in Australia at the time were Passionist priests on Stradbroke Island, off the Queensland coast, who left in 1846, and the Sisters of Mercy in Perth. The men had little in common with other missionaries to the Swan River Colony, who belonged to British Evangelical Protestant movements that were spreading their philanthropic endeavours out into the colonies. Jessie Mitchell described them as being 
'characterised by lower-middle class or artisan backgrounds, passionate religious faith and a strong belief in hard work, individualist aspirations and the value of the respectable bourgeois home' (Mitchell 2011, p. 4). They were typically married couples with families and little money and in Perth they worked with Aboriginal children, who they kept in dormitories, away from their parents' influence. The only missionary in the colony in 1846 was the Methodist Reverend John Smithies, who in 1845, after repeated deaths, moved his children's mission to the suburb of Wanneroo and then to York, east of Perth, but the deaths continued and the mission was closed in 1854 .

Salvado was fortunate to begin his work in 1846 in the Victoria Plains, north of Perth. Lands to the east and south of the town were already settled and under cultivation but in this district the Aboriginal custodians of the land, the Yuit people ${ }^{1}$, continued to live as hunters and gatherers in small family groups on defined tracts of land according to their strict codes of law and sustaining spiritual beliefs, seeing only the occasional explorer or shepherd. Initially Salvado and Serra chose the approach of itinerant missionising to come to know the Yuit people and their culture and, through personal example, to begin their conversion. Salvado's party of men lived and travelled with them, shared their food and shelter, tended their children, healed their sick and wounded and performed other tasks that their hosts 'found most bothersome'. Etchings in a document presented to the Pope to elicit his support depicted the men as benevolent figures ministering to grateful noble savages but their lived experience was far different (State Library of Western Australia, 77600P). Salvado recorded that their Yuit hosts tolerated them but rejected their efforts to evangelise. Instead the Europeans were being transformed as they trudged through the bush in their black habits, patched with kangaroo fur and tied at the waist with kangaroo gut, and shoes made from wood and kangaroo skin (Stormon 1977, p. 53). The men suffered extreme hardships and emotional strain and one of the party died. After months of debilitating conditions Salvado felt obliged to find a permanent mission site and, drawing on Yuit knowledge, he selected excellent pasture and farming land on the banks of the Moore River, some 161 kilometres from Perth.

\footnotetext{
${ }^{1}$ Also spelt as Yuid. Bob Reece notes that Salvado called the Victoria Plains Aboriginal people Murara but that they now refer to themselves as Yuet. This name was used in their 1997 Native Title Claim (Reece 2008, fn 46, p. 141).
} 
The site was named Nova Norcia or New Norcia after the birthplace of Saint Benedict (Harris 1994, p. 296). A small synod met to discuss future directions for the Benedictine mission effort in Western Australia and the mission was opened on the $1^{\text {st }}$ of March, 1847.

The foundations of Salvado's vision were explained at the synod meeting. The mission would comprise a Spanish village-based farming community of Benedictine monks and local Aboriginal land-owning groups. Salvado believed that this was vital for success: remaining within their traditional territories with their land held in trust for them by the missionaries would give Aborigines a sense of 'social stability' denied to those forced off their lands (Russo 1980, p. 136). Salvado believed that only in this way would they come to respect a civilised way of life. On the mission families would adopt a settled life in cottages grouped around a central monastery and chapel. Instructed by the monks the men would work on mission land and their own small plots and contribute to their keep while their wives looked after the home and the children attended school from home for a few hours each day. Through patient explanation and the monks' lived example, they would all gradually learn the Christian way of life as well as 'moral and civil improvement' (Russo 1980, pp. 158-9). The result would be a community where monks and Aborigines shared the 'products of their labours [...] the values of their lives' and 'a sense of belonging' (Russo 1980, p. 125). Salvado insisted that the mission be kept segregated from the outside world. His observations of colonists' abusive treatment of Aborigines and their 'degrading' influence drove his determination to create a 'buffer zone' where they could remain until they were 'mentally and technically prepared to live among the white population' (Russo 1980, p. 136).

This vision may have appeared novel to local colonists, accustomed to the small mission children's home, but the model of settled farming villages had precedents in centuries of Catholic missionary endeavour with Indigenous peoples in North and South America; for example, the 21 missions set up in Texas and California by order of the Spanish Crown in the eighteenth and early nineteenth centuries to convert Native Americans to Christianity and sedentary agriculture and to extend settlement in the area. Salvado was also heir to the Benedictine missionary tradition dating back to the earliest years of the Christian Church in Europe. The Benedictine path involved far more than preaching for 
conversion. Through their own labour the monks created productive farming lands, built monasteries, churches, schools and villages, encouraged local people to adopt agriculture and the habits of work, improved their social and cultural conditions and promoted a love of learning amongst their children. For the monks the Benedictine Rule laid out a common-sense, practical monastic way of life based on spiritual devotion and manual labour as the essence of spiritual discipline, organised around the ideals and bonds of monastic family life and values of obedience, humility, charitable care for the sick, young and the elderly and hospitality to visitors (Dubos 1974). This created a meaningful and sociable way of life that contrasted with the isolated, lonely lives of most missionaries in the Australian colonies. The 1846 Synod had explicitly recognised the central importance of the Benedictine Rule for Salvado's mission:

[...] the way of life of the Benedictines, occupied as they are with prayer, preaching and work in the fields, was the only one, according to the verdict of experience, to inspire confidence and secure the conversion and proper civil formation of the natives. (Stormon 1977, p. 71)

Over the years Salvado steadfastly maintained the Benedictine stance that in mission work 'religious instruction and physical work, both at the same time, ought to take the first and leading place' (cited in Hasluck 1970, p. 98).

There were also glimpses of Salvado's vision in the 1837 Buxton Report's exposition on British colonial policy, especially its advocacy for missions on large reserves of land to achieve Aborigines' 'social and political improvement' through instruction in the techniques of agriculture, the habits of work and a settled and Christian way of life (cited in Hasluck 1970, p. 55). The report recommended the recognition of Indigenous land ownership and rights to negotiate payments and compensation for land taken over for settlement. Revenue raised in this way would be used to finance the missions. What was missing was Salvado's insistence that the people should live in missions on their own land. Also, in contrast to Salvado, who looked to work with all age groups, the Report recommended that education and training of the children should be 'among the foremost of the cares of the missionaries' (British Parliament: House of Commons 1838, p. 83). Although the Report was received enthusiastically in 
Britain, its recommendations were largely ignored in the Australian colonies, which had contributed little to the report, and the British government did not actively promote their implementation there.

As we have seen, Salvado's vision was out of step with the profound pessimism about mission endeavour in the Australian colonies, where the fate of Protestant children's homes had convinced most officials and missionaries that they were 'doomed to failure'. In the early 1840s the British Secretary for State concluded: 'I have the greatest doubts as to the wisdom or propriety of continuing the missions any longer. I fear that to do so would be to delude ourselves with the mere idea of doing something' (cited in Harris 1994, p. 23). His sentiments were repeated in evidence from Lutheran missionary William Schmidt to the 1845 Select Committee on the Condition of the Aborigines in New South Wales, appointed to consider 'the best means of promoting their welfare', that efforts to civilise had been 'in every experiment a pitiable as well as a mischievous failure' (cited in Harris 1994, p. 120, p. 131). Missionaries pointed to the many practical reasons for their problems - lack of funding, internal disputes, the colonists' immoral example and Aboriginal deaths - however, most blamed what Schmidt called 'their deplorable degradation and wretchedness' (cited in Harris 1994, p. 120). Salvado later commented that their ideas were 'nothing better in fact than [those] of the settlers, and for this reason the result was much the same' (Stormon 1977, p. 120).

The missionaries' conflicted opinions blocked their vision of any positive outcomes for the future. They agreed that Aborigines had souls and were capable of redemption but also that they were on the lowest scale of humanity and that contact with colonists only further degraded their condition. There was a growing conviction that they were doomed to extinction and so mission work was futile. They could see no further than protection in segregated missions from the worst abuses of colonisation and removal of Aboriginal children from their families to be 'Christianised and civilised'. An exception was Bishop Polding, who offered an explanation based on Aboriginal experiences of colonisation that must have influenced Salvado's strong convictions:

[...] the want of success must be attributed to the bad feeling and want of confidence, naturally caused by the mode in which possession has been taken of their country occupation by force, accompanied by murders, ill-treatment, ravishment of their 
women, in a word, to the conviction on their minds that the white man has come for his own advantage, without any regard to their rights. [...] Let charity and Christian equity [...] be used, and from esteem and affection will proceed confidence. Without this you will neither civilise nor Christianise. (Cited in Harris 1994, p. 121)

The missionaries' views reflected general attitudes in the Australian colonies that were driven by the imperatives of economic development and expansion and buttressed by racial doctrines and belief in the absolute superiority of the 'British race'. These attitudes would crystallise in the late nineteenth century in social Darwinian beliefs in the inevitable, God-ordained extinction of Aboriginal people. But already in 1851 an editorial prefiguring these theories in the Perth Gazette explained that 'so certain is this result to follow colonisation that we may almost look upon it as one of the mysterious ways of Providence, it is out of human power to alter or fathom' (Shellam 2012, p. 114). Salvado was 'attuned' to the influence of racial theories and challenged his contemporaries' assumptions, explaining that the deaths were the result of 'white man's disease, arsenic poisoning, and murderous shooting' (Shellam 2012, p. 115).

New Norcia Mission was opened on 1 March 1846. During its formative years, from 1846 to 1867 , Salvado advanced his vision 'by the sweat of his brow': 'dressed in dungarees [...] he drove his bullock cart, felled trees, ploughed, sewed, and planted' (William 1967, n. p.). He also honed his skills as entrepreneur, politician, businessman, religious leader, negotiator and musical performer, notably raising 70 pounds at a piano concert he staged in Perth. Developing the mission meant creating links with powerful individuals, obtaining funding and recruits, acquiring sufficient and suitable land, establishing a profitable pastoral and agricultural enterprise and attracting Aboriginal people to the mission. In doing so Salvado had to work across several local and transnational domains: the Swan River Colony, Australia's other settler colonies and the British colonial government; the Catholic diocese in Perth and the colonial Church hierarchy; the Benedictine Order and the Roman Catholic Church, centred in Rome; his allegiances and patrons in Spain; and the Yuit people inside and outside the mission. This required a leader with intellect and vision, a man of the people who was also a sophisticated cosmopolitan with the patience and stamina to surmount the obstacles he encountered. 
Salvado could expect little financial assistance from Perth. The governor provided no funding to establish the mission and from 1862 contributed only 100 pounds per annum. Nor could the small Catholic congregation in Perth assist; for a time mission earnings were siphoned off for its support and Salvado had to resist pressure to make New Norcia an ongoing source of revenue for the Perth diocese. The mission had to rely on its developing pastoral and farming enterprises and the generosity of benefactors in Europe. Campaigning for funds and recruits necessitated Salvado's long absences in Europe and he travelled there five times between 1846 and 1900. Using his erudite skills and contacts in high places he gained the patronage of leading Church figures in Rome and royalty in Europe, including the Queen of Spain and the Spanish Royal Family and the Kings and Queens of Sicily and Naples. Generous donations and volunteer recruits were the foundation of a prosperous, self-supporting mission. On his first trip between 1849 and 1853 Salvado raised over 7600 pounds in donations and recruited a band of thirty-eight mainly Spanish and Italian Benedictine lay and religious brothers, many of them skilled artisans and farmers. Such support distinguished Salvado's enterprise from other missions in colonial Australia that struggled to survive with limited funding and unskilled workers. However, Salvado's intention to train two Yuit boys who accompanied him to Rome to become missionaries for the West Australian field was not so successful. Conaci and Dirimera, baptised Francis Xavier and John Baptist, were introduced to Pope Pius IX and royalty and entered training to become Benedictines, showing great promise in their studies. Tragically, both died: Conaci in Italy in 1853 and Dirimera two years later on his return to New Norcia. Dirimera's brother, taken to Rome by Bishop Polding, had died there in 1850 . The boys reportedly 'pined away' and the priests were devastated by their loss. Salvado made no further efforts to recruit Aborigines to the order (Brendan Hayes, cited in Zwartz 2010, n. p.).

Salvado also differed from other missionaries in the way he was able to negotiate differences with fellow colonists and his religious colleagues and leaders. He became actively involved in Church politics in the colony and in Rome, principally to protect the interests of New Norcia. Between 1853 and 1855, while in charge of the Perth diocese, he built up support for his work by reuniting divisions in the parish, calming anti-Catholic sentiments and meeting 
with political and business leaders. His decision in 1848 to take on British citizenship no doubt assisted. Earlier conflicts with the Perth diocese convinced Salvado of the need for independence from its control and he petitioned the Pope to this end. In 1859 the Pope declared New Norcia an abbey free of any diocesan control and appointed Salvado as Bishop and Abbot of New Norcia. In the same year all mission lands were transferred to his name. Salvado's involvement in church affairs in Europe ensured a public profile there and ongoing support. In 1864 he visited Rome to speak against central Church control of Catholic missions and three years later the Pope issued a statement guaranteeing the independence of New Norcia with Salvado as Abbott for life. This earned New Norcia the nickname of 'little Paraguay', reflecting the political and economic independence insisted on by earlier Jesuit missionaries for their reductions in Paraguay.

Salvado needed all his skills as a negotiator and communicator to persuade local Yuit people to settle at the mission. They could not be forced to live there, although spreading white settlement increasingly circumscribed their choices. As Salvado later recorded, they had their own strong code of law and a deep and satisfying system of spiritual beliefs. He wrote that it was by healing their sick and wounded and sharing food with them and appeasing their curiosity about the harvests of wheat and his explanations of Christianity that he gained their trust and drew them into the mission (Stormon 1977, p. 82). However, observers elsewhere have noted Aborigines' purposeful use of missions to protect themselves from settler violence and obtain food as their land and resources were taken over, as well as their feelings of friendship and compassion for the missionaries. Perhaps the Yuit people envisaged a kindly sharing of resources with these clumsy strangers met in the bush. Certainly during the early years at New Norcia families came and went between the bush and the mission, taking their children with them or leaving them behind where they could be fed and taught new skills. Salvado wrote in 1856 how they helped with ploughing and the harvest: '[A] few days ago there were 25 Australians here; more have arrived. They have to be given time, and allowed to go away on their own business they usually come back, and bring others with them. It is hard work, but not, as some say, impossible' (cited in Shellam 2012, p. 117). Clearly the people had no intention of simply abandoning their way of life. 
From Salvado's return in 1853 the mission began to resemble Salvado's imagined monastic village. The contribution by the Benedictine lay and religious brothers to the self-sufficiency of the mission merits special mention. Their integrated regime of manual labour, prayer and strict discipline made Salvado's plans a reality. They provided a willing and reliable pool of skilled labour and knowledge not readily available to other missions that typically depended on one or two overworked married couples and unpaid and often forced Aboriginal labour. Led by Salvado the men were bound together by the rhythms of life laid down in the Benedictine Rule: 'mass, meals, saying of offices, study and manual work throughout the day' and their shared missionary and religious vocation (Woodward 1994, p. 29). Photographs show the men lined up in monotonous black habits, many with faces hidden behind long beards. The diary of Spanish brother Manuel Beleda documents the psychological and physical pain they often experienced. Some repeatedly sought to escape into the bush despite becoming disorientated and lost and their fears of 'savage' natives. The diary also notes a 'strong sense of caring and affection' for their Aboriginal charges but also misunderstandings and conflict, an inevitable outcome of the collision of cultures (Woodward 1994, pp. 21-36).

Salvado's optimism and faith in his enterprise was in contrast to his fellow colonists. He recorded his admiration for Aborigines' intelligence and physical stamina and was convinced they were capable of learning a new way of life. While most colonists believed they could only become labourers and domestic servants, Salvado wrote in his memoirs that if the natives carefully cultivated their intellectual faculties, they would be capable of any kind of training, whether in the arts or in the sciences' (cited in Conde 1999, p. 112). He had the example of the success of Dirimera and Conaci, who excelled in their studies in Latin and other subjects in Italy. He was also eager to learn about their way of life. He learned to speak the Yuit language and wrote admiringly that it has many sonorous sounds, like the most harmonious ones in Spanish, and supple sweet-sounding ones, like the most attractive in Italian' (Stormon 1977, p. 132). He appreciated the strong moral code and recognised the significance of music, dance and ritual in their lives, all of which he documented along with invaluable information about religious beliefs, myths, foods, healing practices, social organisation, marriage rules, land ownership, funeral rites, body decoration, language and songs (Stormon 1977). 
Concerning marriage and family Salvado recorded that the girls were married at puberty, usually to older men in polygamous relationships. Young men went through long stages of initiation in religious beliefs and practices before they could take a wife. Mothers bore a small number of children who were 'few and well spaced' (cited in Green 1989, p. 197) and Salvado noted that parents had a 'most intense feeling' for their children and that a father 'would not give his son to anyone else for all the gold in the world' (Stormon 1977, pp. 137-8). They demonstrated an 'excessive' tenderness towards their children:

They are never punished, whatever they do, because their parents say they are too small to understand the reason. [...] The only correction given by parents is a scolding, which may or may not be listened to, and even this takes place only after the children have had their own way. (Stormon 1977, p. 137)

However, like other missionaries Salvado was also a 'self-conscious agent of change' who articulated the need for development and intervened to remodel and transform the people and their way of life (Jolly \& Macintyre 1989, p. 7). He endeavoured to prohibit practices he considered sinful or degrading or that hindered conversion, such as polygamy, although he objected to the ruthless suppression of traditional ways practiced by many other missionaries. $\mathrm{He}$ advocated instead a process of 'change by degrees' (Russo 1980, pp. 158-9) and an holistic approach that endeavoured to meet Aborigines' needs - 'temporal as well as spiritual' (Stormon 1977, p. 86). Salvado's approach allowed some mixing of the cultures that can be seen in mission photographs of the period. Nevertheless the missionaries brought dramatic changes to the Yuit way of life through their evangelising, appropriation of the land and labour, introduction of European modes of work and material goods and intervention into marriage and family life and schooling for the children. Although Salvado spoke of learning 'by degrees' and presenting chores to Aborigines as 'continual childish play' he was also prepared to use corporal punishment to discipline adults and children (Stannage 1984, p. 34).

Salvado used his knowledge of Yuit language and spiritual beliefs and customs to explain Christianity and later prepared a catechism demonstrating connections between the two (Russo 1980, p. 163). He also drew on the 
people's love of music and performance to create choirs and instrumental groups to perform in church ceremonies and for visitors and he generally encouraged them to be part of the church community. This approach may account for the significant number of baptisms recorded in the mission records. However, while missionaries typically portrayed such outcomes as miraculous interventions, researchers suggest that there was no simple causal relationship and provide responses ranging from cooperation to active resistance to conversion (Jolly \& Macintyre 1989, p. 9). Indeed, some anthropologists question the veracity of claims of conversion, arguing that Aboriginal religious beliefs are such that true conversion is 'a virtual impossibility' and that 'conversions' were usually 'related to economic need or social deprivation or both' (Yengoyan 1993, p. 234).

The Yuit people staying on the mission learned European labour and work skills through daily routines of regular and orderly work, beginning with early-morning devotions and a meal before the monks and Aboriginal men left to work together in the fields or on mission building projects. Salvado was convinced that the men would respond positively to proper recognition and remuneration for their work:

It is no use saying that the native cannot appreciate the value of money or take pride in possession; he readily learns to do both, and then devotes all his energy to increasing his store of worldly goods and to bettering his lot. But if he is made to feel only the burdens of civilized life and not the benefits, and his wages are so low that he sees no point in working for other people's profit, then he prefers the freedom of his nomadic life to the limitations of our civilisation, and goes back to the bush. (Stormon 1977, p. 86)

From 1854 two-roomed brick and iron cottages were provided for the married men who did paid work in communal farming projects or under individual work contracts. Profits from bountiful harvests were shared with them and their families. As their skills progressed they were allocated their own small farming blocks, which they worked under mission supervision with help with equipment, seed for crops, advice and labour. From this they reaped the fruits of their labour and learned values of personal ownership and progress. Salvado told the men that the land belonged to them 'by right [...] and that no one could take it from [them]' (Russo 1980, p. 154). 
Women's work shifted from food gathering to supervised domestic duties. The promotion of the model of wage-earning husbands and submissive, dependent wives and children shifted the balance between the genders. While men were allowed to work outside New Norcia, the women were obliged to remain on the mission unless accompanied by their husbands and approved by the missionaries. Missionaries typically saw Christianity as improving the lot of the women by rescuing them from abuse by white and Aboriginal men. Salvado was convinced that their changing roles and responsibilities would also impact on their husbands and children. The women and young girls were trained 'wholly in European ways' in domestic work and church activities, including singing in the mass and playing musical instruments and the missionaries held up to them 'the ideal womanhood of the Virgin Mary' (Russo 1980, pp. 166-7). These changes acted to undermine women's traditional powers and independence and subjected them to close surveillance to ensure appropriate standards of sexual modesty and behaviour. The missionaries promoted an idealised image of the sanctity of the Christian family and of appropriate relations between men and women. Their interventions changed fundamental aspects of domestic life, notably 'values that centered on kinship, patterns of marriage, the division of labour, residential patterns, eating and sleeping arrangements and the care of children and the sick' (Jolly \& Macintyre 1989, p. 2). They encouraged monogamous marriages between young people of the same age, directed them in the choice of marital partners, supervised their courtship and directed married couples to live as nuclear and Christian families in mission cottages, thereby creating the basis for an enduring mission community. Father Miro was the mission matchmaker who organised girls' marriage partners for decades between 1865 and his death in 1908 (Russo 1980, p. 166). At the same time Salvado used traditional Yuit marriage laws to approve appropriate marriage partners and reject others.

Schooling of the children to prepare them for a settled life at the mission further undermined Yuit culture, yet it was done through a balanced approach that introduced them to vital new skills. Salvado's pedagogy was 'an expression of his Benedictine philosophy of "civilizing" the Aborigines: a balance of spiritual and elementary education with outdoor exercise, practical skills training and Aboriginal cultural practice' (Shellam 2012, p. 122). The building of boys' 
and girls' dormitories (referred to as 'orphanages') in 1858 and 1861 gave Salvado the opportunity to conduct his benevolent work in his own way. An official report in 1854 noted that the boys were doing as well as white children in their lessons and the Perth Gazette write in 1862 that the ten girls in the dormitory were 'as clean and decently clothed as could be expected' and 'gave every sign of being both contented and happy' (cited in Green 1989, p. 67).

Salvado's civilising ideals for the children were represented in a series of photographs for mission patrons depicting them engaged in various religious and secular activities. An 1867 photograph of a lay brother with a group of boys and girls holding the tools and harvests of farm labour demonstrates the rewards of regular and orderly work through the routines of daily and seasonal labour that were crucial to the children's training (State Library of Western Australia Photograph Collection 5770B/9 [73684P]). Harvesting may have been a time for all hands to help, but in fact most work was gender-specific. Boys learned manual work (farming, gardening and trades to earn a living) while girls learned household duties (sewing, washing, cooking and embroidery) and light manual work in the mission orchards and at harvest time. But the photographs also showed the children's drab mission uniforms pointing to the institutional regime of the orphanages: rise at sunrise, dress and wash, prayers, go to church and assist at mass, sing the 116th Psalm, 7 am breakfast, work to 11 am and then take lunch.

Initially at least, Salvado resisted the practice of separating children from their parents in dormitories as well. He sympathised with to their refusal to leave their children with colonists:

[...] would we blame a white man for not sending his son to a person whom he does not know or trust? [...] They would and do hand them over to those white men who have gained their affection, but otherwise they prefer to keep them at their own side, without benefit of education, rather than risk losing them forever. (Stormon 1977, p. 138)

However, once built, the mission's dormitories predisposed the missionaries to adopt the practice of separating children from their parents. This also promised to prevent parents removing their children from school at will, 
perhaps to put the boys through initiation or to fulfil marriage arrangements. However, the practice of sending girls on to the Sisters of Mercy in Perth to be trained to be domestic servants had tragic results, the Sisters reporting that 'civilization seemed to be more than they could bear. They all died young' (Russo 1980, p. 130).

By the mid-1860s it seemed that Salvado's vision had been realised. Archbishop Polding wrote to him in 1863: 'You are the only one who has been able to civilize the unhappy natives' (cited in Conde 1999, p. 113). In the same year the English health advocate and nurse Florence Nightingale, reporting on her extensive survey of indigenous child mortality rates in British colonial native schools, congratulated Salvado as the only one to recognise the 'physiological necessity of engrafting habits gradually through the means of systematic physical training' (cited in Shellam 2012, p. 124). An anonymous watercolour vista of the mission from 1864 depicts this success in a large cleared site with fields of wheat, vineyards and gardens with Aboriginal men and the monks working side-by-side and the mission monastery, chapel, cottages, dormitories and cemetery. The original 'wilderness' is confined behind fences surrounding the site on all sides. In the foreground are the outsiders - the painter with his tethered horse and Aboriginal men wearing traditional buka (cloaks made from kangaroo skins) standing with their weapons of wood and stone before a mia mia and a smoking fire and their visitors from the mission - a monk and an Aboriginal child dressed in mission clothes.

Tragically this was also the turning point when Salvado's dreams began to come crashing down. From the late 1860s to the 1880s successive epidemics of measles, influenza and whooping cough and a 'fatal melancholy' attributed by Salvado to Aborigines' deep despair and grieving for family and homelands now lost to them cut a swath through the New Norcia mission population. New Norcia seemed doomed to follow the fate of missions elsewhere that began with high hopes 'sustained during the first couple of years, followed by a period of gradual decline and ultimate collapse' (Hamilton 1989, p. 244). We can only imagine the grief and trauma experienced by the families losing so many loved ones and the tragic legacy for the survivors. In such a close community no one is immune and Salvado and his men, who had been living with the people for over a decade, must also have grieved deeply. There was also the loss of the 
shared vision of forging an enduring community. Salvado refused to give in to the 'dying race' proponents and responded to Nightingale's driving question 'Can we civilise the natives without killing them?' by seeking answers to the deaths in 'practical causes [that] could be solved with practical resolutions and prevention' (Shellam 2012, p. 125).

Salvado had to be pragmatic in seeking new ways to save his now threatened mission enterprise and he turned to his friends amongst the colony's rich and powerful, like Governor Weld (1869-1874), a practical family man from a leading English catholic family whose solicitude for Aboriginal welfare attracted private commendation from his superiors in London (Louch 1976). Salvado was drawn in to advise on matters such as protection of Aborigines in employment and women from sexual abuse and he helped to implement the new laws as a Protector of Aborigines under the 1886 Aborigines Protection Act. Significantly for the future of New Norcia he joined in the resurgence of mission work with Aboriginal children inspired by humanitarian concern about the welfare of children of mixed descent in town-fringe camps. In 1871 the Anglican Swan Native and Half-Caste Mission was opened in Perth. New Norcia was already receiving Aboriginal children from government officials, priests and some concerned white fathers. Aware that he had no legal powers to detain the children or to force them to attend school, Salvado lobbied Governor Weld for powers of guardianship over them claiming that this would be 'a step in the right direction towards civilizing them' (Russo 1980, p. 190). The resulting 1874 Industrial Schools Act provided that all children voluntarily surrendered by their parents to institutions would remain under the control of the managers until they were twenty-one. Their parents had no further say over their future and children could be apprenticed to employers to the age of twenty-one or put into service for up to five years without their permission. New Norcia and the Swan Native and Half-Caste Mission and the Swan Boys' Home subsequently became industrial schools under the Act. Although not directed specifically at Aboriginal people the 1874 Act marked the first step in eroding the legal rights of Aboriginal parents and children in Western Australia.

All this marked a distinct policy change and break from Salvado's original vision. The new children became the focus for the foundation of a reinvigorated mission population. A visiting doctor commented in the 1890 s that 'the main 
hope of the missionaries is centred on the children' and by 1900 there were ninety resident in the New Norcia Orphanages (Russo 1980, p. 191). Photographs show their resemblance to the drab children's institutions found throughout the British Empire and the children in their mission uniforms gazing unhappily out at the viewer mirror images of institutionalised children everywhere (SLWA 73743P; Haebich 2000, p. 250). Most of the children came from distant parts so they were true exiles, cut off from family and home and the outside world, forcibly kept in an institution designed to propel them into a future as permanent mission residents. Salvado claimed that most were orphans but his heated response to an official inquiry about which of them qualified for government funding as orphans suggested otherwise:

Some [of the children] are bereaved of fathers, others are bereaved of mothers, others are not orphans at all, and others I do not know what they are. They may be orphans in the full sense of the word from what I know of it. I do not know if they are orphans because I never took any interests in that particular matter. (Cited in Harris 1994, p. 300)

Harking back to his original vision he added that 'this Benedictine Mission of New Norcia was never intended to be, and is not at all an orphanage' (cited in Harris 1994, p. 300).

Salvado's abrupt retort suggests his growing frustration with escalating difficulties at the time. To outsiders the mission still seemed to be a thriving village community of monks and Aboriginal families living amicably together. In 1885 it held a million acres of grazing and farming land and was running sheep, cattle and horses and producing wool, wheat, wine, olives and other produce. It was a popular site for official visits and inspired congratulatory public reports. However, the reality was that the mission had changed. Many of the cottages were empty as epidemics continued to ravage the people. Some residents expressed their opposition to new interventions in family life by seeking work outside the mission and children repeatedly escaped from the orphanages in a bid to rejoin their families. Movement of people between the bush and the mission was curtailed and more adults were expelled for bad behaviour (Russo 1980, p. 213 ff). 
Particularly annoying for Salvado was the unaccustomed government interference and criticism that brought him into conflict with colonial officials. A government commission in 1883 unfairly berated New Norcia for showing 'no striking evidence of its good effects (outside of the institution itself) in the neighbourhood or in the colony' (cited in Hasluck 1970, p. 99). During the 1890s Salvado clashed with Premier John Forrest after he ruled that the mission must take full financial responsibility for adult Aboriginal residents. Salvado was angered by discriminatory funding arrangements introduced in 1892 that threatened to reduce New Norcia's annual grant to a quarter of that supplied to the two Anglican children's missions (SNHC and the Swan Boys' Orphanage) when it supported three times the number of children (Hasluck 1970, p. 96). When an inheritance tax law was introduced in 1897 Salvado, who was registered as the sole owner of the mission's land holdings and property, acted quickly to avoid future financial loss by having the mission declared a charitable institution.

However, the real calamity now facing the mission was the threat to its economic survival as a viable pastoral and agricultural enterprise as the Victoria Plains district was opened up to establish a wheat export industry in the colony during the 1890s. This brought a dramatic shift in patterns of land tenure and usage in the region and mounting pressure for New Norcia's extensive land holdings to be resumed by the government or sold off to be carved up into small farming blocks. By 1909 the mission held only 100,000 of its original holdings of 967,000 acres (Haebich 1992, pp. 16-17). Aboriginal farmers who had been encouraged to take up farming plots outside the mission also faced cancellation of the reserved land.

Salvado was well into his eighties when he set out on his final trip to Europe in 1900. While there he appointed a successor who would negotiate new directions and strategies for the Benedictine mission endeavour in Western Australia. Salvado died while he was in Europe and in 1903 his remains were returned to the mission that he devoted his life's work to establish. Under the new direction of Bishop Torres Salvado's vision of a self-supporting community of monks and Christian Aboriginal families was progressively abandoned. The effort to convert Aboriginal souls shifted to establishing Kalumburu mission in the north Kimberley and at New Norcia boarding schools were built to cater for 
the superior education of white children with labour provided by children from the Aboriginal orphanages. Torres also directed the religious community to take up a more refined and secluded way of life. With less need for their labour, Aboriginal adults left to find work with local farmers and by 1911 only 10 men were regularly employed there. Despite Salvado's assurances that the farms they had worked were theirs by right, they also found they had no recognised claims over the land they had tilled. With encouragement from the monks, some families left their children behind for schooling but access to the children was increasingly curtailed. Growing tensions finally erupted into conflict in 1908 and three of the mission's former upstanding residents were sentenced to three months' imprisonment. One of the men subsequently wrote that New Norcia was now 'no home for the native at all. They keep a few hands here to carry bricks because they are cheap but I can assure you that if you are sick they have no time for such a native' (cited in Haebich 1992, p. 19).

Families now living in the surrounding Midlands district found they could only get menial farm work despite their schooling and skills in farming, trades and domestic duties. Accustomed to living a settled life in the mission cottages, they now had to live in tents in temporary camps, often in desperate conditions. Once protected by the mission community, they now experienced the virulent racism of settler farmers moving into the district and the full force of strict legislative controls enshrined in the 1905 Aborigines Act, which now directed the lives of Aborigines in the state and left them vulnerable to forced removal of their children, who could be sent to live in the New Norcia orphanages, which continued to operate until the 1970s.

Despite the disillusion and suffering the memory of Salvado continues on with celebrations on the centenary of his death in 2000 and the occasion of the bicentenary of his birth in 2014. Remnants of his vision and legacy also persist. The mission site has survived, with many buildings still standing, including the monastery. The enduring spiritual devotion of the small Benedictine community, mixed with an entrepreneurial flair, has transformed the monastery town of New Norcia, with its unmistakably Spanish architecture, into a popular religious and tourist destination. The unique New Norcia Archive, built around Salvado's voluminous records about Aboriginal culture, life at the mission and relations with colonists and the Church, survives and prospers with the continuing work 
of translating these records into English. There is also the Aboriginal cultural centre and museum, with a new exhibition opening in 2014 to celebrate Salvado's work. And there is the ongoing connection of Aboriginal families to New Norcia and their determination to document their account of mission history and to assert their custodianship over mission lands that Salvado assured their ancestors of so long ago through actions such as their Native Title Claim, lodged in 1997.

Finally, there is Salvado's enduring Christian legacy, with most Aboriginal families associated with New Norcia today identifying as members of the Catholic Church. 


\section{BIBLIOGRAPHY}

British Parliament: House of Commons 1838, Buxton Report. Select Committee appointed to consider what measures ought to be adopted with regard to the native inhabitants of countries where British settlements are made.

Dubos, R 1974, 'Franciscan conservation versus Benedictine stewardship', in Ecology and Religion in History, eds D Spring \& E Spring, Harper and Row, New York.

Green, N \& Tilbrook, L 1989, Aborigines of New Norcia 1845-1914. The Bicentennial Dictionary of Western Australians, vol. VII, University of Western Australia Press, Nedlands.

HaEbICH, A 1992, For Their Own Good: Aborigines and Government in the South West of Western Australia 1900-1940 (2nd edn, reprinted 1998), University of Western Australia Press, Nedlands.

HaEbiCH, A 2000, Broken Circles: Fragmenting Indigenous Families, 1800-2000, Fremantle Arts Centre Press, Fremantle.

Hamilton, A 1989, 'Bond-slaves of Satan: Aboriginal women and the missionary dilemma', in Family and Gender in the Pacific: Domestic contradictions and the colonial impact, eds M Jolly \& M Macintyre, Cambridge University Press.

HaRrIS, JW 1994, One Blood: 200 Years of Aboriginal Encounter With Christianity, A Story Of Hope, 2nd edn, Albatross Books, Sutherland, N.S.W.

HasluCK, SP 1970, Black Australians: A Survey of Native Policy in Western Australia, 1829-1897, 2nd edn, Melbourne University Press, Carlton.

Jolly, M \& Macintyre, M 1989, 'Introduction', in Family and Gender in the Pacific: Domestic contradictions and the colonial impact, eds M Jolly \& M Macintyre, Cambridge University Press, Cambridge.

Linage Conde, A 1999, Rosendo Salvado or the Odyssey of a Galician in Australia, Xunta de Galicia, Santiago de Compostela.

Louch, TS 'Weld, Sir Frederick Aloysius (1823-1891)', Australian Dictionary of Biography, National Centre of Biography, Australian National University, http://adb.anu.edu.au/biography/weld-sirfrederick-aloysius-4829/text8055, published in hardcopy 1976, accessed online 21 February 2014.

Mitchell, J 2011, In Good Faith?: Governing Indigenous Australia through God, Charity and Empire, 1825-1855, ANU E Press.

ReECE, Bob 2008, 'Killing with kindness: Daisy Bates and New Norcia', Aboriginal History, vol. 32, pp. $128-145$.

Russo, G 1980, Lord Abbot of the Wilderness: The Life and Times of Bishop Salvado, Polding Press, Melbourne.

SHELLAM, T 2012, “A mystery to the medical world”: Florence Nightingale, Rosendo Salvado and the risk of civilisation', History Australia, vol. 9, no. 1, pp. 110-135.

Stannage, T 1984, 'Bishop Salvado: a review of the Memoirs', Studies in Western Australian History, vol. 8: European-Aboriginal Relations in Western Australian History.

Stormon, EJ (ed.) 1977, The Salvado Memoirs: Historical Memoirs of Australia and Particularly of the Benedictine Mission of New Norcia and of the Habits and Customs of the Australian Natives, University of Western Australia Press, Nedlands. 
William, Dom, 'Salvado, Rosendo (1814-1900)', Australian Dictionary of Biography, National Centre of Biography, Australian National University, http://adb.anu.edu.au/biography/salvado-rosendo-2627/ text3635, published in hardcopy 1967, accessed online 21 February 2014.

Woodward, J 1994, 'Manuel Beleda, 1853-1885: His Association with the Mission at New Norcia', New Norcia Studies, vol. 2, pp. 21-36.

Yengoyan, A 1993, 'Religion, morality, and prophetic traditions: Conversion among the Pitjantjatjara of Central Australia', in Conversion to Christianity: Historical and Anthropological Perspectives on a Great Transformation, ed. RW Hefner, University of California Press, Berkeley. Available from: /z-wcorg/.

ZWARTZ, B 2010, 'A boys' own adventure', The Age, http://www.theage.com.au/national/a-boys-own-adventure-20101215-18y6d.html, accessed online 11 February 2014. 
SALVADO AND THE INDIGENOUS AUSTRALIAN: OF THE SAME HUMAN RACE. EQUALITY AND DIGNITY ANTE LITTERAM

Giulio Cipollone

Pontificia Università Gregoriana (Italy)

Doi:10.17075/rsmaa.2016.en.009 



\section{INTRODUCTION}

The raison d'être of this symposium is the second centenary of the birth of Rosendo Salvado, an extraordinary child of Galicia, a Benedictine monk, a missionary in the Antipodes, a bishop. The facets that could be discussed about Salvado are several, and all of them are important: ethnologist and anthropologist, missionary and bishop; his self and his personality; his ideas and his work in a number of European nations and in Australia; his relationship with the 'grandees' of the earth and the humblest members of society.

As is announced in the title of my contribution, I would like to examine here his relationship of 'absolute' esteem for the Australian native, whom Salvado considered to be of the single or the only existing human race, and to have dignity, just as every other human being, by reason of equality among humans.

The parts of this presentation are limited to these aspects: the $19^{\text {th }}$ century and the 'gospel of difference'; Australian Aborigines watch 'white Aborigines'; colonising and missionary whites. Above all, 'whites'. Salvado: white and 'Aboriginal': no mirror image. Another perception: 'one and the same human race'. Another relationship: to walk and live together. And, lastly, a consideration by way of conclusion about equality and dignity ante litteram and ultra litteram in Salvado.

The aim of this study is to present Salvado from a particular and, in a way, unique angle: the great service that he paid to humanity as a tenacious promoter of equality and dignity among humans. Because of this, he was more than one century ahead of successive charters, declarations and preambles of treaties on human rights at a time when the general tendency was to highlight the differences among 'human races', to the point of establishing non-negotiable, immutable levels of values. 


\section{THE $19^{\mathrm{TH}}$ CENTURY AND THE 'GOSPEL OF DIFFERENCE'}

A few years after Salvado's arrival in Australia, and while he openly declared his esteem for Aborigines, who had the same dignity as and were equal to the rest of humans, Salvado proved that Aborigines were as skilful as the English, and even more so than them. For his part, Gobineau published in 1854, at his own expense, a four-volume essay entitled De l'inégalité des races humaines.

According to Finot, it was Count Gobineau who set the early bases of the implacable doctrines of inequality among humans. 'His work is an enthusiastic hymn to the so-called superior races, and a ruthless act of condemnation of those considered inferior. It contains a genuine arsenal of arguments used by every champion of the persecution, oppression and extermination of the weakest peoples and races.' In the fifth part of his volume Finot wonders, 'Are there any peoples condemned to remain eternally inferior in relation or compared to others?' In so doing, Finot was posing this question several decades before a number of holocausts were committed in the name of the assumption that some humans are above other humans. In the conclusion of his volume, Finot writes, 'Races exist, therefore, as a fiction of our brain; they exist in us, but not outside us. This fact, elementary and undeniable to any truly scientific, well-intentioned minds, will never be emphasised enough.'

There is a close connexion between anthropological interest in and the evolving vision of the history and histories of the $19^{\text {th }}$ century, particularly in relation to the encounter with 'the exotic other.'

Darwin's commentaries contributed involuntarily to the formation of negative ideas about Australian Aborigines. This scientist considered them 'simple' in their survival strategies: apart from the weapons that they used for hunting, this referred particularly to their use of the boomerang. In his view, however, this did not mean that they had evolved psychologically. Neither evolutionism nor the previous fixism helped to integrate Aborigines into a developed, evolving community that was deemed superior, which was the white community. On the one hand, Aborigines were considered to be creatures whose race had never been able to evolve over time; on the other hand, they were seen as finite creatures that had never been able to change or, therefore, make any progress. 
During the earliest contacts with Europeans, there were in Australia more than 300,000 natives that spoke over five hundred different languages. However, following F. Myers, in spite of some significant cultural differences among the various groups, a number of common traits could be seen in the diverse Australian society.

The fields of anthropological reflexion on Aborigines concern their social organisation, religion, family relations, gender differentiation and history.

In relation to history, the attention paid to Aborigines' situation has always been present in anthropological research, but the expression of this preoccupation has been, in general, separate from any research that pursues scientific goals. The scope of anthropological research, which was conducted in a mutating context, was either native settlements or missions; and this was why this research insisted, more and more, on distinguishing the traditional features of Australian tribes from their modern traits. Aboriginal studies have recently entered a more participatory stage. The history lessons drawn from Aboriginal life are now taken into consideration, and efforts are made to consider Aborigines less and less as dependent on an 'exotic other', and more and more as populations in which researchers recognise the footprint of shared humanity. More attention is paid to the global situation of Aborigines, immersed in a world dominated by 'whites'. And recent ethnographic studies also show how the essence of Aboriginal culture can be seen in situations of change. In the dialogue between historiographies and ethnohistory, the history of religions is included in its own right as well, as is - even more deeply, as several authors maintain - the history of man's relationship with the 'transcendent'. It is precisely with this sound, current sensibility that we are dealing with this section of the presentation, bearing in mind this 'shared humanity' that Salvado, one hundred and fifty years ahead of the times, intuited as the best way of approaching Aboriginal culture. All of this was based on the principles of the evangelical culture of Christianity, in which he firmly believed, and on his personal rationality and tenacity. 


\section{AUSTRALIAN ABORIGINES WATCH 'WHITE ABORIGINES'}

Following T. Flannery, Aborigines' attitude during their first encounter with non-Aborigines (unknown Aborigines) appears to have had three characteristics: their willingness not to be pugnacious, their lack of defensive intentions and their cooperative behaviour, manifested in their acceptance of the gifts offered to them.

We have some authoritative references from early explorers, such as that of sir Thomas Mitchell, in his work Three Expeditions into the Interior of Eastern Australia - quoted by Salvado in his Historical Memoirs - in relation to Aborigines before the colonisation and before Salvado's arrival in the continent in 1845. 'My experience,' Mitchell wrote, 'enables me to speak in the most favourable terms of the aborigines, whose degraded position in the midst of the white population, affords no just criterion of their merits.' He goes on to describe the Aborigines that his expedition found in the middle of the jungle, who were fine-looking men who lived content and happy inside the enclosure of their forests. The first of these Aborigines who came to their encounter was a beautiful model of a man, very tall and of an independent nature. His manners were severe, his eyes acute and piercing. Mitchell's guide was a not very wellbuilt short man, but he was full of resolution and courage; his perspicacity and common sense made him so necessary to Mitchell that the former was always by the latter's side, either walking or riding a horse. He had came to know the characters of all the Europeans in Mitchell's retinue; nothing escaped his piercing eyes.

Aborigines had always inhabited, known and venerated those places, the same places that the colonists considered hellish. Right from the start, after disembarking, many among the deportees of the first English penal colony had sought freedom in the forests, where they began to live with Aborigines. The white colour of their skin and their 'decolorised' hair had infused a certain fear into the natives, but they later realised that those 'whites' were not the spirits of the dead but just men, who were even unable to secure water and food for themselves. The natives, therefore, received those fugitives as brothers who needed to be helped; and, indeed, this was all the latter wanted: to guarantee their own survival. But what the natives obtained in exchange was estrangement, 
corruption, diseases and death. In sum, the - more or less covert - objective was their extirpation. Soon, added to the humiliation exerted by deported fugitives was that exerted by colonists, whose actions were legally approved of by governments. In their own land, defined as nullius to justify the occupation of the territories, Aborigines were English citizens, but lacked any power in the colonial system: they were deemed 'savages'.

At first, Aborigines did not fight with weapons because they deeply trusted their society's values. They considered 'whites' as brothers whom they could submit to their moral and social standards, to the obligations of traditional society. They subsequently realised that open confrontation, to which they would have wanted to resort, was a utopia, and that there were only two paths available to them: to fight the Europeans, which in a number of places came to occur after a certain period of interaction, or partly to assimilate what the culture of the 'white fella' [white descendants of Europeans] had to offer.

\section{COLONISING AND MISSIONARY WHITES. ABOVE ALL, 'WHITES'}

Actually, Aborigines met three categories of Europeans: galley slaves, citizens and missionaries. The government was responsible for the policies to assist and protect the natives, but at the same time it had to cater, in the best possible manner, for colonists' safety and entrepreneurial spirit. It was these colonists who, together with the local police, had full powers over Aborigines, as their protectors.

At the time of Salvado's arrival in Australia, there were several Protestant missions there. Salvado mentioned two: Moreton Bay, located north of Sydney and opened in 1838 by twelve missionaries. Most of them were married; the Bible was only taught to the missionaries' children, a total of twenty-two, whereas the 'savages' were not taken into consideration. The other Protestant settlement was founded in 1844 at Noongir Creek, but the 'savages' eventually set fire to it. In the context of the natives' civilisation, such attitudes were, according to Salvado, not typical of them. Salvado considered this behaviour similar to the systems adopted by colonists, which, most often than not, implied the pure and simple exploitation of Aborigines. For example, colonists would 
encourage Aborigines to work in their farms, but then they did not give the natives the necessary farming tools or the money to buy them and be able to work independently. Many colonists used Aborigines for different services so as to civilise them. But no monetary compensation was provided for these services, and so the natives were willing to go back to the forests, where their subsistence in the bosom of their families was better than in their employers' properties.

Such unusual foodstuffs as sugar, flour, tea or tobacco held a strong attraction for the natives. Alcohol use caused victims among colonists and Australians, and constituted one of Salvado's main concerns:

The vice of intoxication, that curse imported from the motherland, drives many a family in that colony to misery and ruin. Whether it is what they call 'rum' or other similar spirits, which are carried to and sold in those forests, it is not possible to accept them. There is no doubt that gunpowder, small peppers, tobacco leaves, brown sugar and also a portion of arsenic are, to a large extent, the components of some of those liquors, a small glass of which is more than enough to make any European not only drunk but also ill, and all the more so a native.

The English government itself put pressure on the governors of the colonies so that Aborigines would be treated as humanely as possible. But actually, as Aborigines were considered unable to make any progress and it was a widespread belief that their race would become extinct in just a few years, Christian doctrines turned out to be inefficient, and the benefits of civilisation nontransferable. All the missions struggled to overcome these difficulties - all but one: New Norcia.

In 1845, as can be read in Salvado's Historical Memoirs, the Colonial Secretary, Lord Stanley, appointed an investigation committee in charge of elucidating Aborigines' living conditions in Australian colonies. The aim of the investigation, as entrusted to the Governor of Sydney, Sir George Gipps, was to improve these living conditions.

Poor Australians! Chased by the white population's power and deprived of the freedom they once enjoyed to roam through their virgin forests at will, they are forced to take refuge amidst the leafiness of the woods and on the most inaccessible riffs, which offer 
them provisional shelter, although rarely the means to subsist. In fact, their main source of food, that is, kangaroo and other animals, has fled or has been eliminated. And where is the fair compensation in exchange for the possession of their own land, now seized from them? They are generally seen as brutes unable to receive any religious or civil education, and as Europeans settle in their country that miserable race declines and goes into extinction.

While colonial laws did not encourage Aborigines' integration into civil society, the 'upright', as Salvado defines them, meaning generally certain people among the most representative of Christian and Protestant culture, would put morally aberrant obstacles in his path, such as accusing him of practising slavery in New Norcia. To defend himself from the accusation, which was totally tendentious and made up, Salvado addressed the governor, asking him (as the Queen's representative in the colony) to send the Queen's Counsel or Attorney so that he could examine the relevant women himself. If the counsel or the attorney were reluctant to go to New Norcia, Salvado himself would return the girls to their own land; otherwise, they would be free to continue their travels across New Norcia, as they actually did.

Salvado was aware of how difficult it was to carry out the missionary work for the natives in those Australian forests. Indeed, once the nomad stage had been left behind in favour of their settlement in places suitable for farming, the problem remained of who would physically cater for the maintenance of the missionaries and the Aborigines connected with the mission. Salvado wrote that, actually, Aborigines had been totally abandoned and forgotten, except at the New Norcia Mission.

Other missions had not, in general, drawn efficient plans for Aborigines' wellbeing. While those missionaries agreed that Aborigines had souls and were capable of redemption, many of them relegated the natives to the lowest level of mankind and thought that they would be unable to stand the impact of civilisation. There was, therefore, nothing that could be done but protect Aborigines by keeping them segregated in missions, and encourage the separation of young natives from their families so that they could be 'Christianised and civilised'. 
The radical difference between Salvado and the rest of missionaries, both Protestant and Catholic, is that our missionary monk's conscience clearly told him that he was in Australia for, above all, Aborigines: Aborigines were at the top of his missionary concerns. For Aborigines, respected and beloved, he was ready to give his life. And he did.

\section{SALVADO: WHITE AND 'ABORIGINAL'}

Sheet 329, back, of baptism book no. 17 of the parish of O Sagrario, Tui (Pontevedra), reads,

On the second day of the month of March, year eighteen fourteen, I, Mr Juan Francisco Piñeiro, parish priest of this holy cathedral of the town of Tui, solemnly baptised in said cathedral a child born on the previous day, to whom I gave the name of Lucas Josef Rosendo, a legitimate son of Mr Pedro Salvado and María Francisca Rotea [in the presence of his paternal and maternal grandparents as well as his godparents, Mr Lucas Portela and Mrs Josefa Figueiroa, who had been given the due warnings] ... Witness my hand and seal in Tui, this fifteenth day of November of nineteen forty-three.

Salvado was the sixth of seven siblings, three of whom were priests. Among these was Santos, who was a missionary in Australia with Salvado while his health allowed him to. Msgr Rudesindus Salvado was from the house of Rome, in St Paul Outside the Walls, where he died on 29 December 1900.

Salvado's biography is remarkable. We may point out that he was endowed with excellent natural qualities, travelled extensively across Europe, participated in different cultural fields by reason of his training, enjoyed the citizenship of both his fatherland and England, and because of his rank he held a safe-conduct relating to his role as a missionary and a bishop in Australia. Above all, we should highlight his great humane sensitivity and his extraordinary mental capacity, which, much earlier than many charts, constitutions and preambles to various treaties, had preannounced ante litteram the same dignity for all humans, as well as their absolute equality.

In the first pages of his Relazione, he informs us that he knew nothing about Aborigines when he arrived in Australia; but he kept his spirits high and acted 
the best he could. And, knowing nothing about Aborigines, 'as there were many disagreements about this issue among the inhabitants of the colony,' he immediately wanted to give himself a personal idea of the matter.

From his initial perception of and impression about Aborigines, it may be said that Salvado introduced himself to Aborigines as 'white and Aboriginal'.

Salvado had a strong will, to the point that he used constructively all the actions and energies of the 'ambitious and bold' human being that he was, according to Santiago Rodríguez. He was the main figure in an enterprise that came to be in a very limited area of the vast Australian continent, but one that is still well-known in the whole of Australia today; and, above all, he was able to challenge sensibilities and shatter preconceptions in a country colonised by Anglo-Saxon culture, which was, in many ways, very different from the Spanish culture in which he had been trained. By swimming against the tide (but not doing this as a foreigner, as he had obtained English citizenship), he destabilised the colonists' minds and sought, by all means, to destroy those insurmountable barriers that the government had built, as his Relazione extensively shows.

Salvado's strong vocation was to civilise pagans, to give them the ability to live as citizens in a Christian 'polis', rather than colonise them. By contrast, colonists, who attributed the monopoly of civilisation to themselves, thought that Aborigines were, more often than not, just an inconvenient presence that was being physically eliminated little by little.

Salvado was not familiar with anything that had to do with Aborigines, and he did not know whom he should address to gain some knowledge of those savages' life and customs. After arriving on Australian shores on 8 January 1846, he set off for Perth on foot and arrived there on 16 February 1846. And the $1^{\text {st }}$ of March he stayed briefly in a place that the savages called Nundagunda, approximately one hundred miles from Perth. Together with the first missionaries, he was forced to stop, owing to their lack of water, in the middle of a thick forest as unknown to them as were the savage nomads and cannibals who inhabited it, and who a few months earlier had killed an European there; also, one of them, who later became Salvado's best and most loyal companion, had eaten in that jungle a sister whom other savages had killed, roasted and turned into their shared food.

With a view to being more efficient in finding out the secrets of their beliefs, custom and usage, 
I, too, became a nomad and wanderer like them, and accompanied them here and there through those unknown forests, carrying the provisions of flour, rice, tea and sugar that I was able to bear on my back. And, while the provisions lasted, the savages took most of them for themselves. But, once the provisions ran out, they, as good friends, shared with me the best part of the snakes, lizards, worms, roots and similar good snacks that they carried with them.

The Aboriginal 'hands-on school' taught Salvado some lessons. First, an European missionary could not survive very long living that nomad existence, as sleeping out in the open, on the naked earth, in every season of the year, never doing it two consecutive times in the same place, and not having anything to eat but nauseating food, was certainly not healthy or suitable if one wanted to preserve the vigour and physical strength that he needed. Second, as the savages did not stay anywhere permanently, it was impossible to supply any provisions to the missionary who accompanied them, especially because the provisions that would have been enough for him for two months would be over in two days or less if they happened to find a large group of savages. Third, the savages never travelled in big groups; instead, each family moved separately, as often did individual natives. A missionary per family would therefore be required, which was unfeasible. Fourth, the time spent on religious instruction for those nomadic savages would have to be limited to the hours of rest only, when they used to take a break and cook their food. This is why any instruction provided while those savages carried on with their nomadic life, in contact with other savage families, would bear little or no fruit. Fifth, any theoretical religious instruction provided to those rough savages without the powerful efficacy of the example, i.e., without giving them the chance of seeing it put into practice, would never cause the effect intended in those poor wretches, who had never seen any religious cult practice. For, indeed, faith is communicated not only through words, but also through sight. 


\section{NO MIRROR IMAGE. ANOTHER PERCEPTION: 'ONE AND THE SAME HUMAN RACE'}

It may occur that one has an image of something without having the knowledge of it. It is a universal psychological fact that we reject what does not belong to our own group and may virtually hamper the balance of such group. The process described as 'mirror image' is important in the analysis of actions and reactions involving group hostility. It is easy - and, incidentally, beneficial - to discredit our enemies using the worst attributes taken from our imaginary and from our own group's worst experiences.

To have more accurate knowledge about the natives and their character, behaviour, learning capacity, etc., we should refer to Salvado's 1851 Historical Memoirs. In the third part, Salvado devoted twelve chapters to the natives. $\mathrm{He}$ clearly expressed his opinion on the Australian race and the historical time when they were assumed to have originated and which marked their presence in that continent. Next, he discussed the physical features, the intellectual capacity and the religious beliefs of the Yuat Noongar people, their customs and also their language, which Salvado found sweet and musical by reason of its sonority, similar to that of the Spanish language, and particularly poetic. Salvado himself expressed another opinion that revealed his great affection for the natives: 'In their natural state, while not yet contaminated or exasperated by Europeans, Australians are hospitable and have feelings of generosity and politeness.' $\mathrm{He}$ also quoted the words of a governor and explorer, Sir Eyre, who stated in his work Journals of Expeditions of Discovery into Central Australia,

The male is well built and muscular, averaging from five to six feet in height, with proportionate upper and lower extremities. The anterior lobes of the brain are fairly developed, so as to give a facial angle, far from being one of the most acute to be found amongst the black races.

Examining their intellectual capacity, Salvado says that, if they had cultivated their minds diligently, that enterprise would have borne good fruit in them, both in the arts and in sciences. In each colony, Salvado continues, the savages learnt to read and write, and also some arithmetic operations, unexpectedly fast. 
It was because of his life among them that there matured in Salvado a material and spiritual evangelisation dimension that addressed the concrete, tangible development of a community that would eventually be more socially and economically progressive than the way of life offered by governmental institutions and Protestant missions. This was such a complex and complete process of materialisation that it culminated in the 'ornaments of civil society': a cricket team, a choir and two musical bands are indicators of the fact that the early cultural fertilisation of New Norcia was as satisfactory as to leave room for other, more psychologically complex and developed expressions.

Salvado was a man as sincere and lively as strong and zealous, capable in his work, always original. His resolved attitude hid a kind spirit, one ready to encourage, to stimulate, to make the talents of each of his natives 'bear fruit'. $\mathrm{He}$ loved them to the point that they were even graceful to his eyes, with their blond hair hidden under clay and grease masks, with their intelligence, with their genuine appearance. Ultimately, even if Salvado shows a natural inclination to present these creatures of God in the best possible way, cosmic religions were considered to be imbued only with superstitions and magic. Hence Salvado's incessant work, his constant, straightforward dialogue, resulting from his attitude of esteem for 'human nature' in itself, personal fulfilment and the effort to better oneself on the way to a 'highest form of civilisation'.

This evidence is surprising for many reasons. $19^{\text {th }}$-century literature was based, as we have seen above, on the existence of a number of fixed, immutable 'categories', such as that of understanding humanity as divided into several 'races', or another category, that of dividing the inhabitants of the Australian continent in the $19^{\text {th }}$ century into 'blacks and whites'. This is why the following observation is surprising and admirable: Salvado never talked about 'races' but about one single human race, and never wrote about blacks and whites in his Relazione but about savages, or natives, or Australians, and Europeans. Only once did he mention the 'race', but in relation to horses. 


\section{ANOTHER RELATIONSHIP: TO WALK AND LIVE TOGETHER}

Aborigines had to see things for themselves first, to latter ask themselves where 'invisible' ideal references for a given type of behaviour might come from. The 'Aboriginal polis' was beginning to have suggestive, alternative standards of comparison.

For Aborigines, every vital expression of everyday objects and events had an spiritual counterpart, and the concept of progress could be attained by establishing antagonisms. In consequence, transforming their cultural aspects was unthinkable. Their philosophy of life was perhaps closer, by analogy, to ecoanthropology, which studies the relationships between man and the natural environment. This ethical reality has, incidentally, already been presented in the book of Genesis, in which God creates the world and entrusts man with the task of fully realising the work of creation. The text is full of poetry, of symbols, of evocative words, as well as the myths of the creation of Aborigines.

When Salvado refers to Aborigines, he uses certain adjectives that changed over the years. It should be remembered that, in contrast to the European perception of the term, Salvado uses the word 'savage' repeatedly in his Relazione, but not with a pejorative meaning. 'Savage' is employed simply to denote a person from the jungle, from the woods. This term is understood as synonym for other 'equivalent' words: 'natives', 'indigenous population', 'Australians'.

Undeniably, the natives' strong faith in their own culture drove Salvado and his monks to a certain 'Aboriginalisation'. Aborigines, for their part, believed so firmly in their values that they intended to 'civilise the white men', so as to compare their respective values at least, they being reciprocally 'foreign'. But, although these two cultures lived in peaceful communion, the desired osmosis between them did not take place, 'and then I asked myself what should be done.' Salvado proves with facts that he was well aware of this situation.

Emancipation and liberation are processes that were then updated in a historical context in which ethnocentrism prevailed, in which the superiority of the white race was asserted. The latter should be understood as the 'racial supremacy' temptation that is often found in the human being. Christianisation and civilisation appeared to many not as a virtue to be expressed and practiced, but as indisputable qualities that one possessed as birthright. The moral equation 
was simple and could not be challenged: the enlightened English were taking civilisation to 'underdeveloped savages'. These 'savages' had, of course, nothing to lose; quite the opposite. This was what was thought about them, and missionaries had to investigate what were the capacities or the ignorance of those 'degraded human beings', among whom they needed to live. The missionaries' example was assumed to have the power to inspire the savages to give up their customs and embrace the benefits of a 'civilised' culture.

It was believed that Christian faith would achieve what nobody could have done: 'We first convert them, civilisation will follow next.' Only the voice of conscience would be able to eradicate the 'ferocity' of those Aborigines steeped in superstitions and barbarism; their behaviour was such that they remembered the time when Europeans' ancestors, in a state of nudity just like themselves, danced in the mystic woods and scrutinised the entrails of the humans whom they had sacrificed. If Christendom had already dispersed the dark clouds of ignorance once, why fear that the 'miracle' could not be repeated again for these new children of Adam? Australian Aborigines found themselves among insensitive Christian people who were 'civilised' but took possession of and exploited Aboriginal land, destroyed natural reserves of food and brought the vices of drinking and prostitution. Subjected to the brutality of colonisation, the natives had fallen to a level lower than that of their Aboriginal condition.

But 'by virtue of what moral, religious or social principles should a strong race, with intent to raise others to its own level, condemn a weak, disarmed race to death by extinction? Was such intention not supposed to be a way of bringing life and prosperity to all?' Only an enlightened Christian society would be able to offer Aborigines the possibility of spiritual and material salvation.

\section{CONCLUSION. ANTE LITTERAM AND ULTRA LITTERAM. EQUALITY AND DIGNITY}

\section{Ante litteram}

Important writers of the $19^{\text {th }}$ century, and also of the following century, persisted in not wanting to see in Aborigines anything other than 'Aborigines', 
not bowing to the evidence of their humanity. This evidence is surprising for more than one reason. $19^{\text {th }}$-century literature rests upon fixed, immutable categories such as that of understanding humanity as divided into several 'races', and also that of dividing the inhabitants of the Australian continent in the $19^{\text {th }}$ century into 'blacks and whites'. Hence an observation that seems marvellous: Salvado never talked about races, but about one and the same human race, and never wrote about blacks and whites in his Relazione but about savages, or natives, or Australians, and Europeans. And only once, as we have said, did he mention the issue of 'race', but in relation to horses.

Now, in the process of creating his documentary and literary production, Salvado broadened the horizon by elevating Aborigines to a plane of 'equal dignity' with those who were not Aboriginal. Furthermore, he made an effort to produce plenty of documentation and literature in order to counter any opinions revealing self-satisfaction, lack of respect or even the non-recognition of Aborigines' human nature.

For some scholars, or simply explorers or colonisers, Aborigines were not human, or it was highly doubtful that they were. In any event, they were not 'European' and would never be. In view of this 'ferocious' criticism, Salvado devoted his entire life to refuting these theses and prejudices.

We have had the opportunity to see that Salvado fully threw himself into the cause of Australian Aborigines, to the point of being ready to give his life for it. And, incidentally, he did. If beauty is in the eye of the beholder, then everything is clear. Salvado considered Aborigines his brothers and sisters because, insofar as they really were of the same human race as him, he thought that they were as skilful and capable as Europeans, and even more than them. Salvado defended Aborigines from those who looked down on them and hindered the progress of their civilisation. Even the mission had become, paradoxically, a place of refuge for unprotected, 'incapable black Aborigines', victims of the abuse and violence of 'civilised' white colonists.

By reason of his personal temperament and his deep faith in Christ and his Gospel, moulded by the Rule of Benedict of Norcia, Salvado wanted to be an Aborigine with Aborigines. During his first contact with Aborigines, whom he never called 'blacks', Salvado expressed his 'predisposition' to and 'bias' in favour of the indigenous inhabitants of Australian lands, in a highly supportive 
manner and with great admiration for them. No matter how, Salvado wanted to be in Australia for Aborigines. He was much less interested in all other things, for which he paid the price of seeing his behaviour frowned upon and, in a way, being considered a 'renegade' by Europeans, who did not recognise him as 'one of us'. In actual fact, Australia was 'visited' by different categories of nonAborigines (or 'other Aborigines'), Europeans: galley slaves, colonisers eager for power and gold, explorers fascinated and curious to find an exotic country where they could circumspectly admire plants, animals, nature in general and Aborigines.

Salvado, however, acted with 'other' very clear intentions: to announce the Good News with the aim of suggesting another way of organising Aboriginal settlements and their group laws. He did this with the utmost respect, as we have seen. He became an Aborigine with Aborigines, a nomad with nomads. This was the only way of not frightening the Aborigine, having himself accepted and, only then, starting to communicate with gestures the other form of civilisation that sustained the missionary's life. It was the discretion of delicate acculturation: walking together to live together, to put forward 'another model of sociability'.

Salvado did take every opportunity to highlight the multiple bad habits and vices that the Europeans in Australia had adopted, and he did so to the extent of wanting to protect Aborigines, by all means, from the contact with / infection from Europeans.

Two hundred years after Salvado's birth, these reflections may help read the writings of this brilliant son of Galicia as those of a pioneer of ideas, which have come to be the principles that have inspired charters, constitutions and preambles to various treaties, written hundreds of years after Salvado expounded his beliefs with deeply meaningful gestures that do credit to him and to the land of his birth.

\section{U Itra litteram}

The four signs of contemporary times - i.e., socialisation, the emancipation of the working classes, women's access to public life and freedom for the oppressed - were, much earlier and to a great extent, interpreted and put into practice by this Benedictine monk. It was, in short, a missionary action understood as 
evangelisation for a consequential human promotion. It is easy to recognise in his Relazione the realisation of these extremely important issues. Different answers in different contexts. We should not forget about Aborigines' ability to learn the game of cricket, to the point that they exceeded Europeans in skill to play, and beat them in a number of competitions: 'I praised God, from the bottom of my heart, for having awarded them such a wonderful result, which at the same time was the most splendid answer to the malignant accusations of their detractors.'

\section{EVANGELISATION AS PROMOTION OF THE RIGHTS OF 'HUMANS'}

Even though no one spoke of human rights in the $19^{\text {th }}$ century as they are currently interpreted - for example, in the subsequent Universal Declaration of the Rights of Man of 1948 - Salvado paid special attention so that the dignity of the person would be protected and respected at all times. Unfortunately, the problem of 'negative rights' persisted, even in the context of religious institutions. As the other missions, both the Catholic and the Protestant ones, generally had to focus more specifically on providing spiritual assistance to colonists, they paid little attention to their mission among Aborigines, ignored their cultural traditions, ignored the respect due to their vital demands. In New Norcia, respect for the people, for their needs, for the defence of Aboriginal and colonial laws, constituted a particular world in a community that swam against the tide of the cultural perspective of the time, and where the existing viewpoints and life values reminded of primitive Christian communities, which were governed by the imperatives of community spirit and justice.

Leaving cannibalism behind, abolishing vengeance, stepping out of the narrow tribal circle, having access to sciences, songs and music, as well as abandoning ancestral superstitious practices, which somehow closed the cultural horizon to the entry of new data; the status of women, the fatalism of a favourable or nefarious reality, which established and fixed attitudes and relationships among Aborigines; managing to understand that charms were actually good for nothing except for provoking an emotional, euphoric reaction in the clan, and many others - all of this shows the steps towards a better society 
that, thanks to Salvado, were taken by Aborigines, considered 'equal' to white Europeans, with the same dignity, on the same plane of equality and of the sole human race.

Today, two hundred years after the birth of this brilliant son of Galicia, a pioneer of human rights, we still find his message and his work as a most modern example to follow. Meanwhile, and if we limit our considerations to the West, there are multiple charters, constitutions, declarations and preambles to various treaties that enshrine the right/duty of practising equality among humans, respecting their 'non-negotiable' dignity. Still, violations of human rights and laws and attitudes against these rights, all of which are perpetrated by humans themselves, are common offences that are evident to all. Having said this, there appear to be two major or critical points in this path for humanity: the perception of the other and the potential room for inclusion or for marginalisation. These are delicate processes and any steps taken will be uncertain, to come to the realisation of the great effort that it has required for the human species to eventually understand that there is only one human race, and that persisting in maintaining palisades that marginalise people depending on the colour of their skin is a truly 'inhumane' phenomenon, because it does not work for the good of the entire humanity.

The world today has assumed the perception of the existence of one single human race, and perhaps expresses this perception as the healthy tension of being and/or coming to be one single human family. The concepts of civilisation and culture are combined with civilisations, multiculturalism and global vision of the world and the human being; hence the commitment, as Salvado stated, to an inclusive vision of all humans beyond one's own ethnic group, beyond skin colour, religion or community or group identity. The testing ground for the human rights and duties observed and practiced ante litteram by Salvado is the fact that those rights and duties are still a building under construction and appear as pierres d'attente or, in English, toothing stones, as an ideal and a commitment ultra litteram, beyond conventions, constitutions and declarations.

In this massive building under construction, which is still open, for the sake of equality and dignity of humans and among humans, we should not ask ourselves what is going on but, rather, what we 'can do', as Denis de Rougemont warned. And there is much we can do. Ultra litteram.

Salvado's exemplary personality sounds like a guarantee of success and commitment. We need to believe it. 
'ON MY GROUND':

INDIGENOUS FARMERS

AT NEW NORCIA

1860s-1900s

\section{Tiffany Shellam}

School of Humanities and Social Sciences

Deakin University

Doi: 10.17075/rsmaa.2016.en.010 


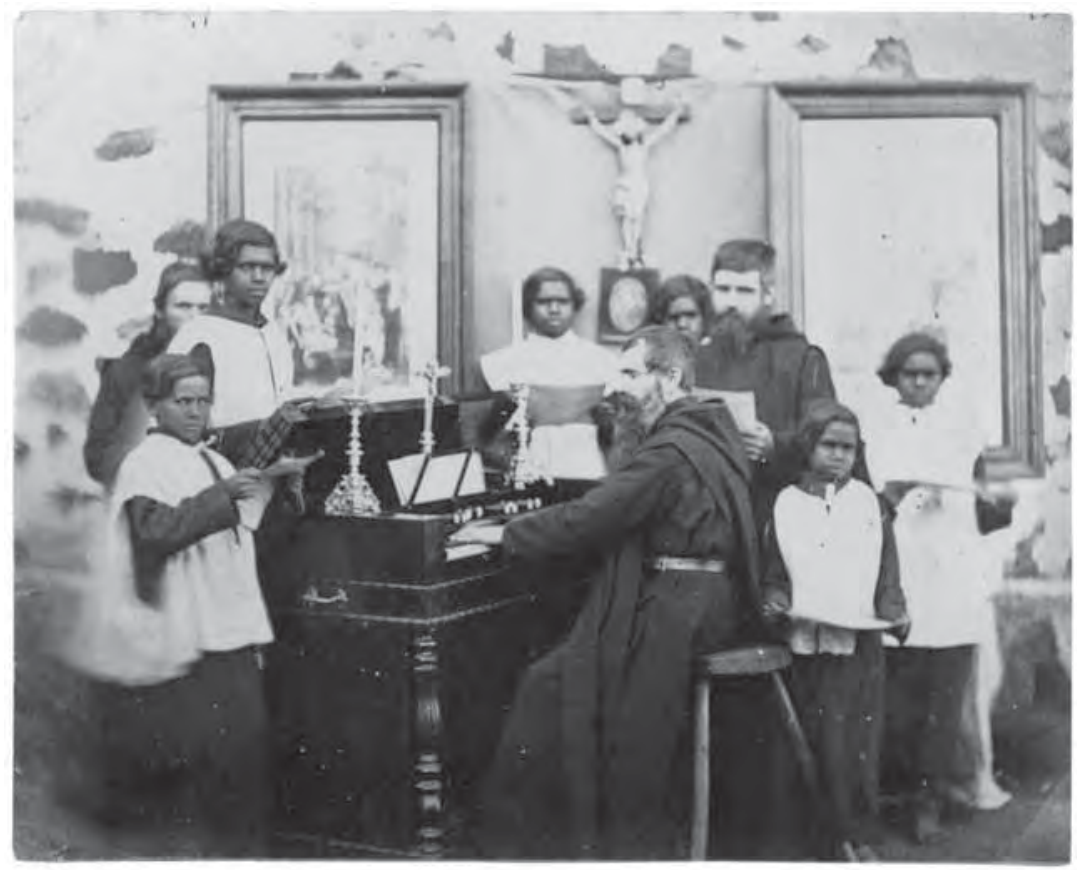


[T] hey have their own standard of right and wrong, which no argument of the white man can change. Good actions and morals they acknowledge and praise as "Kuoba" - right; but whatever is bad, they evidently regard and express as "Winda" - wicked. If occasionally the wildest Aborigines find a difficulty in defining the difference between killing a sheep and a kangaroo, - both of which are equally fed by grass and roam at large in their bush - it should, before condemning them, be first taken into consideration who shows the greatest dulness [sic] of moral perception, the unauthorized occupiers of their woods who kill, themselves, as many kangaroos as they can, or the original owners of that land, who take such things as they find upon it for the preservation of life ${ }^{1}$.

These words were penned in 1867 by Father Venancio Garrido, a Benedictine monk at New Norcia Aboriginal mission in Western Australia. They form part of his lengthy report on the mission which was requested by the Colonial Secretary to be forwarded to the Aborigines' Protection Society in London. In 1871 Father Garrido's report was collated alongside other 'information' about Aborigines in Western Australia that had been collected by missionaries and government agents, and was printed by the government printer. The above statement suggests two issues that I will draw out in this chapter: the Aboriginal residents at New Norcia had a strong sense of right and wrong; and the Benedictine community at New Norcia considered them to be the original owners of the land, which was, in 1867, increasingly occupied by pastoralists.

Between the 1860s and the early 1900s Aboriginal residents at New Norcia acted on and expressed their understandings of 'right' and 'wrong' in relation to land through group protests, letters and petitions to colonial authorities and the

\footnotetext{
${ }^{1}$ V. Garrido (1871), 'Letter from Rev V. Garrido to Colonial Secretary, Western Australia, 21 December 1867', in Information Respecting the Habits and Customs of the Aboriginal Inhabitants of Western Australia, compiled from various sources, Perth, government printer, ordered by the Council to be printed, 16 January 1871, Council, Western Australia, 1870-1871 and 1872, A.8 (State Records Office of Western Australia), p. 15.
} 
mission community. These Aboriginal statements, I argue, developed and had taken shape during the Aborigines' residence at New Norcia, where, in collaboration with the missionaries, the Aboriginal community developed a mode of political expression. Elizabeth Elbourne has written about some Indigenous men who, in the 1830 s, attempted to participate in international networks concerned with the reform of British colonial policy, using 'international languages about rights and property ownership'. She writes: 'They needed to present themselves in print or in person on the British stage as, to some extent, disembodied actors with the concomitant ability to move between different cultural worlds. They also often needed to be Christian, or at least to present themselves as such. They had to present themselves [...] in ways familiar to the British, while posing as examples of the universal man posited by early nineteenth-century liberalism'3. Benedict Cuper, Charles Ponan, Luke Mourdey and Paul Piramino were Aboriginal farmers at New Norcia who wrote letters of protest to authorities about their land. These men understood, to an extent, the political setting in which they were engaging, developing a political network and articulating their rights as they understood them and in a language that would sometimes bring justice. This activism can be discussed alongside the story of Coranderrk Aboriginal Station in Victoria. Set up in 1863 by the government to confine Victoria's remnant Aboriginal population, Aboriginal settlers at Coranderrk made the country their own, successfully settling and farming the land. However, the government re-dispossessed these people, taking them off their country in the 1870s. The Coranderrk residents' political mobility in response to government actions was described as a 'rebellion' by Diane Barwick, and more recent scholarship has located Aboriginal actions as operating within Aboriginal ideas of 'right' behaviour ${ }^{4}$.

\footnotetext{
${ }^{2}$ E. Elbourne (2005): 'Indigenous peoples and imperial networks in the early nineteenth century: The politics of knowledge', in Phillip Buckner and R. Douglas Francis (eds.), Rediscovering the British World, Calgary: University of Calgary Press, p. 63.

${ }^{3}$ E. Elbourne, 'Indigenous peoples and imperial networks', p. 61, quoted in Tim Rowse (2012), 'The identity of Indigenous political thought', in T. Rowse and L. Ford (eds.), Between Indigenous and Settler Governance, Hoboken: Taylor and Francis, p. 96.

${ }^{4}$ D. E. Barwick (1998): Rebellion at Coranderrk, Laura E. Barwick and Richard E. Barwick (eds.), Canberra, Aboriginal History Monograph, 1998; R. Broome (2006), “There were vegetables every year Mr Green was here": Right behaviour and the struggle for autonomy at Coranderrk Aboriginal Reserve', History Australia, vol. 3, no. 2.
} 
Besides the seminal work of Anna Haebich on Aboriginal farmers in 1984, the narrative of New Norcia's founder, Rosendo Salvado, and his enlightened approach to 'civilising' Aboriginal people has overshadowed the story of the political agitations of some of the mission residents in the early $1900 s^{5}$. This chapter reflects on the ways in which, determined to retain access to their land, Aboriginal farmers at New Norcia cultivated a space through their written protests to colonial authorities, in which they negotiated their changing identities of being both 'Aboriginal' and settled 'farmer'. Through their experiences of collaborating with the missionaries on petitions at New Norcia, and writing letters, this chapter aims to shed light on how some of the Aboriginal residents understood writing as a vehicle for action ${ }^{6}$.

\section{NEW NORCIA: LAND, LABOUR AND CIVILISATION}

Two Spanish Benedictine missionaries, Rosendo Salvado and Joseph Serra, arrived in the Swan River Colony in January 1846. They had been informed by Bishop Brady that large numbers of Aboriginal people lived in the Victoria Plains district, $100 \mathrm{~km}$ north of the Perth township. Salvado and Serra trekked to the banks of the Moore River and began setting up a mission on the ancestral country of the Yuit people.

Humanitarians in the mid-nineteenth century frequently linked Aboriginal futures with the adoption of agriculture. As Jessie Mitchell has written, in Europe in the eighteenth and nineteenth centuries, 'the cultivation of the soil and the private enclosure of land were primary factors legitimising ownership and denoting civilization'7. Rosendo Salvado had a vision of a self-supporting

\footnotetext{
5 A. Haebich (1988): For Their Own Good: Aborigines and Government in the South West of Western Australia, 1900-1940, Western Australia: University of Western Australia Press.

${ }^{6}$ For other examples of indigenous people utilising literacy and colonial modes of expression to voice their rights and concerns, see A. Curthoys and J. Mitchell (2011): "Bring this paper to the good Governor": Aboriginal petitions in Australian Colonies', in S. Belmessous (ed), Native Claims: Indigenous Law Against Empire, 1500-1920, Oxford: Oxford University Press, pp. 182-204; T. Banivanua Mar (2013): 'Imperial literacy and indigenous rights: tracing transoceanic circuits of a modern discourse', Aboriginal History, vol. 37; R. de Costa (2006): A Higher Authority: Indigenous Transnationalism and Australia, Sydney: UNSW Press.

7 J. Mitchell (2011): In Good Faith: Governing Indigenous Australia Through God, Charity and Empire, 1825-55, ANU E Press, p. 96.
} 
mission village after the model of European monastic towns where Benedictine monks would live alongside local Aboriginal families. Salvado and other missionaries who joined him at New Norcia hoped that the 'Australians', as he often called the indigenous population, would experience community stability as they would remain on their land. The 'Australians' would settle down as landholders and this would, Salvado hoped, assist them in the transition to 'civilised' life. Salvado realised that land was also crucial for the mission's success and survival - the government had granted Salvado 20 acres in 1847 - and Aborigines who came to New Norcia provided the labour required to further develop the mission. As Salvado wrote in 1857, 'with the help of 31 natives' the community 'reaped 20 acres in a day and a half".

Henry Reynolds has argued that hard labour was believed to prepare Aborigines for Christian conversion by teaching discipline, punctuality, sedentary life and the acceptance of European authority ${ }^{9}$. Humanitarians' advocacy for Aboriginal land retention was not neutral; indigenous 'compensation' for dispossession was tied to Christian agricultural instruction, and was often funded through the proceeds of dispossession itself. The Imperial Waste Land Act of 1842 , for example, required up to $15 \%$ of revenue to be allocated from the sale of 'waste' lands - Aboriginal country - to be spent on Aboriginal welfare ${ }^{10}$.

Salvado's focus on Aboriginal family units and his encouragement of men becoming farmers was central to his civilising plan. At Coranderrk, in Victoria, the station manager, John Green, also tied married life with Aboriginal stability, recruiting Aboriginal men with the promise of finding a wife ${ }^{11}$. The importance

8 'Letter from Salvado (New Norcia) to Garrido (Caltura), 27 December 1858', NNA Correspondence 2-2234A/13.125, translated from the Spanish by Teresa de Castro.

${ }^{9}$ H. Reynolds (1990): With the White People, Melbourne: Penguin, p. 90.

${ }^{10}$ For a discussion on this issue in the Swan River Colony, and the agitation for acknowledgement of Aboriginal land proprietary rights in the 1830s-40s, see A. Hunter (2012): A Different Kind of 'Subject': Colonial Law in Aboriginal-European Relations in Nineteenth Century Western Australia, 1829-61, North Melbourne, VIC: Australian Scholarly Publishing, especially chapter 8.

${ }^{11} \mathrm{~J}$. Green to Commissioners, 21 May 1877, Royal Commission on the Aborigines of Victoria: Report of the Commissioners, government printer, Melbourne, 1877, p. 83. See J. Cruickshank's work for examples on how humanitarian concerns about marriage were central to debates about civilisation in the early-mid- $19^{\text {th }}$ century, J. Cruickshank (2008): “To exercise a beneficial influence over a man”: Marriage, Gender and the Native Institutions in Early Colonial Australia', in Evangelists of Empire?: Missionaries in Colonial 
placed on family units is evidenced in a range of archival documents at New Norcia: census lists grouped families together, naming married couples and their children; Salvado stressed in his Memoirs (1851) that the family unit should become the locus of the property holding and the acquisitive behaviour he was keen to encourage ${ }^{12}$.

Land rewards were also given to Aboriginal couples who got married. The first Catholic marriage of Aborigines at New Norcia was on 24 February $1862^{13}$. The mission provided a two-roomed furnished brick cottage to married couples, a larder of provisions and steady employment ${ }^{14}$. Salvado believed labour and land improvement were the pathways to civilisation. Therefore, Salvado was sympathetic to Aboriginal land ownership and sensitive to his settlement on Aboriginal country. When, in 1864, he requested that he be the sole trustee of the land that New Norcia occupied (previously being trusted to Salvado and four local settlers) Salvado included in his letter to the Colonial Secretary that he had received 'the assent of the Aboriginal natives [who were] interested' in this matter ${ }^{15}$. This humanitarian desire to settle the Yuit on their own ancestral country was not intended as a way of preserving pre-colonial Aboriginal culture, but radically re-shaping it. Protected agricultural labour was offered as a form of redemption. However, as Mitchell argues: 'missionary efforts to change Aborigines into farmers of their ancestral lands' can also be seen as 'attempts to incorporate Aborigines into this colonising project in a rather more collaborative

History, Amanda Barry, Joanna Cruickshank, Andrew Brown-May and Patricia Grimshaw (eds.) [online], Melbourne: University of Melbourne eScholarship Research Centre. Available at http://msp.esrc.unimelb. edu.au/shs/missions, date accessed: $3^{\text {rd }}$ December 2013.

12 E. J. Stormon (1977): The Salvado Memoirs: Historical Memoirs of Australia and Particularly of the Benedictine Mission of New Norcia and of the Habits and Customs of the Australian Natives by Rosendo Salvado, 1851, translated and edited by E. J. Stormon, Western Australia: University of Western Australia Press.

13 'Letter from Garrido (New Norcia) to Salvado (Perth), 24 February 1862', Correspondence in Spanish, 2-2234A/17.053, NNA, translated by Teresa de Castro.

${ }^{14}$ Letter from R. Sala: 'Five weddings were celebrated a short while ago for recently-converted Aborigines. A new well-furnished cottage was given to each couple', in El Misionero Romualdo: Un vivo recuerdo que a los hermanos, parientes, amigos y conocidos les dedica un amante de su familia, Palma de Mallorca, translated and cited by David Barry (2005): 'A Mallorcan in New Norcia: Missionary Brother Romualdo Sala', New Norcia Studies, September, no. 13.

15 'R. Salvado to Colonial Secretary, 10 August 1864', NNA, 174 2-2234A/19.174. The subsequent legal document is located in NNA, 202, 2-2234A/19.202. 
way. Aborigines would, missionaries hoped, be integrated into the colonial economy while kept safely isolated from European dependence and $\sin ^{16}$. Father Garrido, reflecting on the civilising policy at New Norcia in his 1867 report, wrote how 'it is essentially of greater advantage to any Aboriginal native who learns how to support himself by his industry or manual labour, as an agriculturalist, teamster, shepherd, shearer, or trademan [...] than only to know how to read, write, cipher...'17 Mitchell has argued that 'missionaries and protectors frequently described their mission's progress in terms of 'simultaneous religious enlightenment and 'industry and general steadiness' ${ }^{18}$. This idea of progress and steadiness was part of the language that Aboriginal farmers and settler supporters adopted or engaged with when writing to the authorities about retaining their land.

As soon as a site for the mission was chosen, Salvado began to lobby to expand the original government grant of 20 acres, and by the end of 1848 the mission had over 1000 acres, and over 1000 sheep. Crops and vegetables were also grown. Initially Salvado assigned a piece of land and cattle each to four Yuit men: Bilagoro, Dwergan, N-yalbinga and Takencut in April 1848. By the end of 1857, these men were living in the four cottages that had been built specifically for them and their families. These gifts of cottages, land and cattle were aligned with Salvado's goal of ensuring Aboriginal private ownership. Dwergan's cow, for example, was branded with a D to denote his possession of it - a graphic index of property held individually rather than communally ${ }^{19}$. As Father Garrido stated in 1867, 'The possession of private property is, no doubt, an encouragement to industry, and a salutary check upon the natural indolence of the Australian Aborigines' ${ }^{20}$. Progress, no matter how slow, was always celebrated by the missionaries. In 1856 Fr Martelli reported to Salvado

16 J. Mitchell (2004): "Country Belonging to Me": Land and Labour on Aboriginal Missions and Protectorate Stations, 1830-1850', ERAS Journal, edition 6, November [online]. Available at http:// artsonline.monash.edu.au/eras/, date accessed: $5^{\text {th }}$ December 2013.

${ }_{17}$ V. Garrido to Colonial Secretary, Information Respecting the Habits and Customs of the Aboriginal Inhabitants, p. 16.

18 J. Mitchell: “"Country Belonging to Me”, p. 5.

19 'Letter from R. Salvado to S. Salvado, 12 May 1856', Correspondence, NNA ACC 202234A/11.062.

${ }^{20} \mathrm{~V}$. Garrido to Colonial Secretary, Information Respecting the Habits and Customs of the Aboriginal Inhabitants, p. 16. 
that 'It was heartening to see land being cultivated for the natives, but it would be better still if the natives themselves could be doing the work' ${ }^{21}$. Two years later Salvado wrote: 'The Australians are clearing ground to work for themselves. They made their own choice of land and chose well. They work together in groups of two or three, which cooperate when need arises'22. Salvado found this work 'very encouraging' and had 'high hopes for the success of the enterprise'23.

New Norcia, and Salvado as superintendent, quickly became a model of success in Western Australia and other colonies, where it received positive press. Sydney's Archbishop Polding wrote to Salvado in August 1863 congratulating him on the 'unequalled success in civilising the natives' 24 . There was much weighing on Salvado's success in 'settling' the Australians. In a letter from Corrons in Palermo in 1862 to Salvado, Corrons stressed that 'the [Benedictine] Order is in decline, and the Australian savage may be the plank on which the shipwrecked Order reaches safety ${ }^{25}$.

Learning new farming techniques was not limited to Aborigines. As Mary Eagle has written, the Aborigines at New Norcia 'taught skills of firestick farming, water management, reading the weather, rain-making, living off the land, rug-making, music and dance' to the Brothers ${ }^{26}$.

Salvado paid the Aboriginal residents who farmed and also helped the men establish their own farms. The wages they earned enabled them to take up a section of land to work and crop for their own benefit. Salvado set up a banking scheme, encouraging the men to buy animals or equipment ${ }^{27}$. As Salvado described his scheme:

\footnotetext{
21 'Letter from Martelli (Toodyay Village) to R. Salvado (Fremantle), 23 June 1856', Correspondence, NNA ACC 2-2234A/11.081.

22 'Letter from R. Salvado to V. Garrido, 25 June 1858', Correspondence, NNA ACC MF12 41.07.

23 'Letter from R. Salvado to V. Garrido, 25 June 1858', Correspondence, NNA ACC MF12 41.07.

24 'Letter from Archbishop Polding (Sydney) to Salvado (New Norcia), 21 August 1863', Correspondence, NNA 2-2234A/18.108.

25 'Letter from Corrons to R. Salvado, 27 January 1862', Correspondence, NNA 2-2234A/17.021.

${ }^{26}$ M. Eagle (2002): 'Monop of New Norcia and the Victoria Plains', New Norcia Studies, 10, p. 50. Eagle has written that Aborigines who specialised in detecting water were sent to make wells for the mission. 27 'Letter from V. Garrido to Colonial Secretary', Information Respecting the Habits and Customs of the Aboriginal Inhabitants, p. 12.
} 
to have Aboriginal men working without recompense or reward would make them feel the burden of civilisation without its advantages [...] should there be no recompense, the natives prefer the freedom of bush life, and they return to the bush. Properly instructed the aboriginal acquires a just idea of both the value of money and property, and diligently studies thenceforth how we may better his condition ${ }^{28}$.

In May 1860 Salvado requested a tillage lease of fifty acres from the government 'to encourage all the more to agricultural pursuits several aborigines of the mission'29.

Partly as a consequence of dwindling numbers of Aboriginal residents due to the devastating measles epidemic of 1861, Salvado began to recruit Aborigines from further afield. The mission began to house Aboriginal people from all over the south-west, not just the Yuit people and surrounding groups, but Aboriginal men and women from Bunbury and Albany in the south, Champion Bay to the north, and eventually, Roebourne and Wyndham in the far north. In 1870 Salvado also began accepting juvenile offenders who would have otherwise been sent to Rottnest Island Aboriginal prison ${ }^{30}$. Like other Aboriginal missions and stations around Australia, such as Coranderrk in Victoria and Poonindie in South Australia, Aboriginal people who came to New Norcia from other parts of the colony had already been dispossessed from their traditional lands and some had been institutionalised in other mission stations, surviving the transformations caused by pastoral invasion. Both New Norcia and Coranderrk became thriving and economically self-supporting communities. Similarities between New Norcia and Coranderrk are clearly evidenced in the early photographs of these two mission stations. As Anna Haebich has pointed out, photographs of these two stations are:

\footnotetext{
${ }^{28}$ E. J. Stormon: Memoirs, chapter 10.

29 'R. Salvado to Colonial Secretary, 18 April 1860', quoted in G. Russo (1977): Lord Abbot of the Wilderness: The Life and Times of Bishop Salvado, Melbourne: Polding Press, p. 154. The tillage lease was granted on $28^{\text {th }}$ May 1860.

${ }^{30}$ N. Green and L. Tilbrook (eds.) (1989): Aborigines of New Norcia, 1845-1914: The Bicentennial Dictionary of Western Australians, volume VII, Western Australia: University of Western Australia Press, p. xviii.
} 
dominated by tangible evidence of progress: cleared lands under crop, new buildings, Aboriginal children surrounded by the trappings of civilised life, sedentary families posed in the manner of colonial settlers outside their cottages, and scenes of community outings where residents relax on river side picnics or engage in the manly sport of cricket. Details of composition, the subjects' clothes, grooming and posture, and contextual props all combine to provide compelling proof of the missionaries' success ${ }^{31}$.

We might add to Haebich's statement that such photographs are also 'compelling proof of the Aborigines' success in adapting their land use. While acknowledging that such colonial photographs were for propagandist purposes and, no doubt, involved incidents of Aboriginal coercion, Haebich also argues that some photographs reveal 'intimations of Yuit people being in place in their country and of monks and transferred Aboriginal children coming to accept New Norcia as their home'32.

\section{AN ABORIGINAL TOWNSHIP}

New Norcia’s Aboriginal residents quickly became competent farmers. Father Garrido reported to Salvado in Rome in 1867 that 'Benedict Cuper and Albert Turgiel are ploughing and sowing their respective fields with two teams of oxen. They use an English plough, all their own property. They help each other alternately so that neither they nor the animals, whom they feed on hay, get tired. Tom Yawell and Bob Nogolot do the same'33. These men showed promising signs of missionary 'success' and the Brothers never missed an opportunity to report on their progress. One Brother, Romualdo Sala, wrote to his family in Spain, also in 1867, proudly describing how at New Norcia 'The shearers are Natives of the country who live in the Mission. They are very nimble. The "ringer" is called Benedict Cuper, and I've seen him shear 78 sheep

\footnotetext{
31 A. Haebich (2009): 'Unpacking Stories from the New Norcia Photographic Collection', New Norcia Studies, vol. 17, p. 57.

${ }^{32}$ A. Haebich (2009): 'Unpacking Stories...', p. 59.

33 'Letter from V. Garrido to R. Salvado, 21 April 1867', quoted in G. Russo, Lord Abbot of the Wilderness, p. 155.
} 
in a day. A. Thomas Yanel [Yawel] [has shorn] 61, William Manop [Monap] 55, Richard Caniel [Canhiel] 57, Donabuf [Donabut] 58 [...]'34. Father Garrido also boasted about the shearers in his 1867 report: 'This very year, our natives have shorn 5413, that is, one of them (a half-caste) has sheared more than any European shearer employed here, namely 1421 sheep in twenty five days, paid at 4s 6d per score, £15 19s 8 1/2d’35. This was Benedict Cuper.

Benedict Cuper, born in 1846, was the son of an Englishman from Chittering in the Victoria Plains, and a Yuit woman named Maria Junnop. The historical record does not give us the details of exactly when and under what circumstances Cuper came to New Norcia, but by the time Salvado had returned from a trip to Europe in 1853, Cuper was listed as a resident. In 1857 there was a written agreement which stated that Cuper would stay at the mission until his $25^{\text {th }}$ year on an unspecified wage ${ }^{36}$. On 1 March 1861 he was on the books as a 'general servant', for which he was paid 20 shillings per month ${ }^{37}$. In 1865 Cuper made an agreement to wash and shear sheep, to be paid at a rate of 4 shillings and 6 pence per score and two bottles of colonial wine for every flock washed (minus his expenses and those of his men). This agreement Cuper signed himself on 9 September $1865^{38}$.

Cuper married Ellen Pangieran in 1862, and they were frequently used as pin-ups of New Norcia's success until Ellen's death in 1877. Ellen Pangieran, whose married name became Mary Ellen Cuper, was not a local Yuit woman, but had been born in Bunbury, to the south of Perth, in 1847. Because her mother had been deserted by Mary's European father, the government authorities considered that she was unable to bring up her daughter on her own. As a consequence, Mary was sent to New Norcia. While the patchy historical record tells a story of Benedict as a competent farmer, a star cricket player and a steady man, Mary Ellen is also renowned for being the first postmistress at New Norcia. Salvado taught Mary Ellen Morse Code in 1873 and she earnt a wage

\footnotetext{
${ }^{34}$ R. Sala: 'Letter Six', 16 October 1867, El Misionero Romualdo, translated and cited by David Barry (2005): 'A Mallorcan in New Norcia', p. 45.

35 'Letter from V. Garrido to Colonial Secretary', Information Respecting the Habits and Customs of the Aboriginal Inhabitants, p. 17.

${ }^{36}$ N. Green and L. Tilbrook (eds.) (1989): Aborigines of New Norcia, pp. 33-34.

${ }^{37}$ N. Green and L. Tilbrook (eds.) (1989): Aborigines of New Norcia, p. 34.

${ }^{38}$ N. Green and L. Tilbrook (eds.) (1989): Aborigines of New Norcia, p. 34.
} 
of $£ 30 \mathrm{p} / \mathrm{a}$ as postmistress. While Aboriginal men at New Norcia thrived in agricultural pursuits, some of the women found success in other employment.

Throughout the 1860s and 70s New Norcia received many visitors who published their observations in the local press. In April 1862, one visitor described the community. They visited the cottage where Benedict and Mary Ellen lived and were impressed that 'cleanliness and order seemed to reign everywhere'. Mary Ellen 'gave every positive promise of being a good and careful housewife' 39 . Visitors frequently requested to see the Aboriginal men cultivating the land, and Salvado showed them a field where they saw Benedict Cuper and Peter Nowarr and a 'Brother busily engaged in clearing, burning, and preparing the ground for the ploughing season'. This visitor was impressed with the work they saw, commenting also on how the profits of the previous year's crops enabled Cuper and Nowarr to purchase 'bullocks, drays, ploughs' and to 'comfortably maintain a wife!' ${ }^{20}$. The Aboriginal residents got used to performing for these observers, and were aware of the importance of appearances, particularly when Protestants came to scrutinise the Roman Catholics' civilising process. When Reverend Meadowcroft, a congregational minister, visited in 1873, Fr Santos Salvado sent a message notifying Mary Ellen two hours before he arrived, 'therefore', he wrote 'the sleeping room and the other rooms were swept, clean and the girls half-dressed-up and wearing shoes, waiting for Rev Meadowcroft in the living room' ${ }^{\prime}$.

Another New Norcia resident, named Charles (Carlos) Ponan - the stepbrother of Benedict Cuper's wife, Mary Ellen (they shared the same European father), and whose ancestral country was near Bunbury - frequently worked with Cuper as a team, hunting and breaking in horses (caballeros), sinking wells, repairing fences and harvesting New Norcia landholdings, as well as operating their own farms ${ }^{42}$. Ponan arrived at New Norcia in 1862 . He was baptised that year with Cuper as his godfather. In 1869 he married Mary Lucy

\footnotetext{
39 Perth Gazette, 11 April 1862, p. 4.

${ }^{40}$ Perth Gazette, 11 April 1862, p. 4.

41 'Letter from S. Salvado (New Norcia) to R. Salvado (Perth), 15 February 1873', in Spanish and English, NNA 2-2234A/28.23, translated from the Spanish by Teresa de Castro.

${ }^{42}$ Examples litter the correspondence between Fr Santos Salvado and Rosendo Salvado in 1876-79; Salvado, List of "caballeros", 31 December 1876, ACC 2-2234A/file 31.163, translated from Spanish by Teresa de Castro.
} 
Bouyacan and they had seven children ${ }^{43}$. Under the Land Regulations of 1872 Crown land could be set aside for use by Aborigines, as a gazetted reserve. Small reserves were created as sites for mission schools. New Norcia received 29 acres in 1874 and Cuper and Ponan received land under this scheme ${ }^{44}$. However, Benedict also had a large field which he cleared and cultivated prior to this. In September 1869 , as the mission community was expanding, Salvado decided to divide Benedict's field into three portions: 'the part from the road towards the river, which has the best soil, for Benedict; the part that goes to the mission, for Ponan; and the area that goes to the road towards the river and between the 2 fences, for Manop [Monap]'45.

In 1876, Salvado wrote in his Diary that Cuper and Ponan 'own their own farms of 100 acres each around New Norcia, and farm them under the supervision of a Brother. Last season I paid them $£ 50$ each for their harvest ${ }^{\not 46}$. Historian George Russo has described how, for the benefit of these farmers, Salvado established a 'rural bank to provide credit for their farms. They could buy sheep and cattle, which meant that they could become pastoralists in their own right, and with the experience gained at the mission they could settle themselves anywhere in Western Australia' ${ }^{27}$.

By the 1880s New Norcia had achieved pastoral dominion in the Victoria Plains district, including several mission outposts, causing some settlers to state that Salvado had 'picked the eyes out of the country'48. In 1885, 967,000 acres were held by New Norcia. One reason given for holding such a big area was the need for funds, to maintain their very large establishment of Aboriginal dependents at the mission. Another was the original aim of settling Aboriginal families on different blocks of land to be parcelled out to them for their exclusive use ${ }^{49}$.

\footnotetext{
${ }^{43}$ N. Green and L. Tilbrook (eds.) (1989): Aborigines of New Norcia, p. 119.

${ }^{44}$ L. Tilbrook (1983): Nyungar Tradition: Glimpses of Aborigines of South-West Australia, 1829-1914, Western Australia: University of Western Australia Press, pp. 28-29.

45 'Letter from R. Salvado (Rome) to V. Garrido (New Norcia), 21 September 1869', NNA, 2-2234A 124.190, Spanish and Latin.

46 Salvado: Diary, 29 ${ }^{\text {th }}$ March 1876, quoted in G. Russo, Lord Abbot of the Wilderness, p. 212.

47 G. Russo: Lord Abbot of the Wilderness, p. 212.

${ }^{48}$ R. Erickson (1971): The Victoria Plains, Osborne Park, Western Australia: Lamb Patterson, p. 49.

${ }^{49}$ R. Erickson (1971): The Victoria Plains, p. 54.
} 
With a post and telegraph office run by Aboriginal residents (Sarah Minak took over as postmistress when Mary Ellen died), a court house, a police office, a successful Aboriginal cricket team and an Aboriginal choir, New Norcia reflected Salvado's vision of a steady, stable Aboriginal village. In the $1880 \mathrm{~s} \mathrm{New}$ Norcia appeared to be flourishing. Governor Broome's wife, Lady Broome, wrote about the outcome of Salvado's vision after spending a night at New Norcia in 1883: 'One saw the result of it all during the long, pleasant day spent in visiting schools and workshops, going into the neat, comfortable cottages, and finally sitting down to watch a capital game of cricket between the natives and the lay Brothers' ${ }^{50}$. In 1884, Brother Romualdo Sala called New Norcia a 'town of Indigenous Aborigines', and he described the four streets of Aboriginal cottages, listing the names of the male heads of the families who occupied each of the 21 cottages $^{51}$.

While agriculture was the main priority at New Norcia, reading, writing and religious instruction were also central to mission life. The Brothers encouraged letter writing and also urged Aboriginal residents to join petitions that the community was involved in.

In September 1864, 'the first natives', who had been sent from Bunbury to New Norcia by Fr Lecaille, wrote him a letter 'thanking him for his great charity towards them'52. On Salvado's $62^{\text {nd }}$ birthday in 1876, he was in Europe, where he received three telegrams from New Norcia wishing him a happy birthday: 'one from the community, one from the natives and the third one from Benedict Cuper and his wife'53. Letters were sometimes written between New Norcia and the Aborigines who were living and working on the mission's outstations. James Cooper Nindimara, who was based on an outstation at Jibberding, wrote to Salvado in 1889 describing the 'troublesome' Aborigines who visited Jibberding, hoping for 'silavtion [salvation] for the poor sogles [souls] ${ }^{54}$. This letter reveals

\footnotetext{
${ }^{50}$ A. Hasluck (ed) (1963): Remembered with affection: A New Edition of Lady Broome's 'Letters to Guy', with notes and a short life, Letter IX, Melbourne: Oxford University Press, p. 72.

${ }^{51}$ R. Sala: Letter 18, 2 May 1884, El Misionero Romualdo, translated and cited by David Barry (2005): 'A Mallorcan in New Norcia', pp. 48-49.

52 The letter is mentioned in 'Letter from Salvado to Lecaille, 22 September 1864', NNA ACC 205, 2-2234A/19.205.

53 Salvado: Diaries, vol. 2, 1 March 1876, translated from the Spanish by Gustavo Geuna. NNA.

54 'Letter from James Cooper Nindimara to Salvado, 22 August 1889', NNA ACC 2-2234A/44.91.
} 
a division between the Christian/non-Christian Aboriginal population, and the labouring/non-labouring population.

Several Aboriginal people at New Norcia were signatories to a petition in 1865 that Father Garrido organised, requesting that Salvado remain the principal of New Norcia, rather than relocating to Subiaco ${ }^{55}$. It is hard to know if these Aboriginal petitioners signed the petition because Salvado was viewed as the leader integral to their land acquisition.

\section{0: STRUCTURAL CHANGES}

After 1890 many factors contributed to a change in the lifestyles of New Norcia's Aborigines. Following a sustained campaign led by the editor of The West Australian, Winthrop Hackett, to eliminate government support for Church schools and institutions, New Norcia now held total financial responsibility for the adult population at the mission. This reduced funding forced many families to leave New Norcia for outside employment ${ }^{56}$. Salvado expressed his disappointment about this in a statement to the Aborigines Protection Board in 1893: 'It may be as well to add the following natives [six names of Aborigines and half-castes] left this mission with their wives and children this year, intending to earn better weekly wages somewhere else, as one guinea per week to each married native is as much as the mission can afford to pay them'57. In February 1899 Cuper - who had married Matilda Murrichery in 1893 after the death of Mary Ellen - had moved to Wyening, an outpost of the mission. He agreed to make a tank at a rate of 1 shilling and 1 penny per cubic yard. All tools were to be supplied by $\mathrm{Cuper}^{58}$.

\footnotetext{
55 'Letter from V. Garrido (New Norcia) to Salvado (Rome), 8 March 1865', NNA ACC 57, 2-2234A 120.057.

${ }^{56}$ N. Green and L. Tilbrook (eds.) (1989): Aborigines of New Norcia, pp. xviii-xix.

57 'Statement Concerning the Natives (Aborigines and Half-castes) at the Benedictine Mission of New Norcia, on the 31 $1^{\text {st }}$ December 1893', Correspondence Relating to the Proposed Abolition of the Aborigines Protection Board of Western Australia, British Parliamentary Papers, C. 8350, Document F, State Records Office of Western Australia.

${ }^{58}$ N. Green and L. Tilbrook (eds.) (1989): Aborigines of New Norcia, p. 34 . In 1898 Cuper, aged 50 years, was listed as living with Matilda and her children Lucas, Rosendo and Rose Murrichery in house 4, row 1 at New Norcia, before moving to Wyening the following year.
} 
The change of mission superintendent in 1900 following Salvado's death saw mission life become highly regulated under missionary control, and many residents were forced off the mission. Salvado's successor, Abbot Fulgentius Torres, has been identified by historians as the instigator of many changes at New Norcia, in particular with the turn away from a mission for Aboriginal people and towards the education of Catholic settler children, with the change of focus to a cloistered monastery. Katharine Massam has argued that these changes were not so much due to a reluctance to continue missionary endeavour but rather a desire to focus more firmly on monasticism ${ }^{59}$. The missionary effort moved to the Drysdale River Mission, which opened in Napier Broome Bay, on the Kimberley coast, in 1908. Torres drastically reduced New Norcia's large land holdings to just 41,000 hectares by $1909^{60}$. This in turn reduced the need for shepherds and the mechanisation of Australian agriculture further reduced the labour needs of New Norcia. In the 1880s there had been 21 Aboriginal cottages. These were demolished as New Norcia underwent major changes.

Bishop Torres 'encouraged monks and brothers at New Norcia to abandon their outdoor rural work and to lead a more refined and secluded life ${ }^{61}$. Peggy Brock has narrated a similar story at Poonindie: 'By the late 1860s the initial idealism of Hale [Poonindie's founder] and his graduates had dissipated [...] and had been replaced by an institutional ethos of supervision and control' ${ }^{62}$. Similarly, the Kulin residents at Coranderrk experienced a dramatically different structure to their daily life when the popular station manager at Coranderrk, John Green, was forced to leave.

In 1911, one Aboriginal resident at New Norcia, George Shaw, who was very vocal against the changes to mission life, wrote to the Aborigines Department, stating that the mission was 'no home for the native at all. They keep a few hands here to carry bricks because they are cheap but I can assure you that if you are sick they have no time for such a native ${ }^{63}$.

\footnotetext{
${ }^{59}$ K. Massam (2012): 'Cloistering the Mission: Abbot Torres and Changes at New Norcia 1900-1910', Australasian Catholic Record, 89 (1), p. 14.

${ }^{60}$ N. Green and L.Tilbrook (eds.) (1989): Aborigines of New Norcia, p. xix.

${ }^{61}$ A. Haebich: For Their Own Good, pp. 16-17.

${ }^{62}$ P. Brock (2000): 'Mission Encounters in the Colonial World: British Columbia and South-West Australia, Journal of Religious History, vol. 24, 2, June, pp. 170-171.

63 'Letter from George Shaw to Aborigines Department', AF 473/1911, quoted in A. Haebich, For Their Own Good, p. 19.
} 
Despite, or perhaps because of these changes at New Norcia, in the early 1900s several Aboriginal farmers were granted land by the Crown. The government Land Regulations can also be understood as undoing part of the mission's previous success. While granting Aborigines land, the rigid requirements also created failures out of this scheme. As Haebich has argued, 'The conditions under which these blocks were granted created insurmountable financial difficulties for Aboriginal farmers and it was the system of land tenure and the conditions of occupancy [...] which proved the major barrier to Aborigines succeeding on the land'64.

\section{LAND REGULATIONS - ABORIGINAL FARMS}

As Commissioner for Crown Lands John Forrest ushered through a new set of land regulations through the Legislative Council, directed at finding a middle

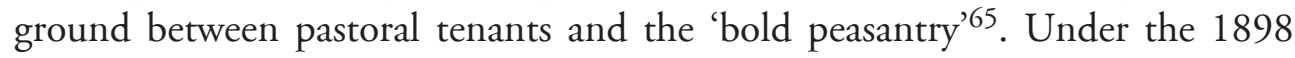
Land Act, up to 200 acres of land could be granted or leased to an Aboriginal on application, for the purpose of residence or cultivation. If certain improvements were not made within a specified period the occupant stood to lose the land, which could then be re-classified as Crown land. To ensure that the land was fully utilised, its transfer was made conditional on the holder carrying out certain improvements within a specified period ${ }^{66}$. The Lands Department followed the recommendation of the Commissioner for Crown Lands in 1895 that reserve holders be required to carry out improvements to their blocks or face having them reduced in size or cancelled. Reserve holders were subject to the terms of occupancy for homestead blocks; within two years of taking up land they were required to erect a dwelling valued at $£ 130$ or have an equivalent area under crop; within five years they were to fence in a quarter of their block and within seven years the entire block was to be fenced.

Several Aboriginal people obtained land under these provisions. In 1906 twelve Aborigines applied to the Lands Department for farming blocks. As

\footnotetext{
${ }^{64}$ A. Haebich: For Their Own Good, p. 30.

${ }^{65}$ R. Erickson: The Victoria Plains, p. 65.

${ }^{66}$ A. Haebich: For Their Own Good, p. 11.
} 
Haebich has written, 'most applied on their own initiative, while others were encouraged in their endeavours by missionaries, employers or well-meaning government officers. Most applicants were mature, married men with young families and considerable experience on the land'67. A large number of these applicants were men who had been educated at New Norcia who had some association with the land through ancestral connections or long-term residence in the areas in which the blocks were located.

The special provision for grants of land to Aborigines was first introduced in the 1887 Land Regulations. However, as Haebich has argued, in introducing this provision the government appears to have had no clear-cut policy on the role of Aborigines in land development. It certainly had no intention of granting Aborigines full ownership of these blocks. Forrest told the Legislative Council in 1886 that the clause was intended merely to allow the Governor to 'give away the land' and the Acting Attorney General, S. Burt, added in support of Forrest that 'a native could hardly be allowed to come under the transfer clause' ${ }^{68}$. The government most likely predicted that the clause would enable the development of Aboriginal farming settlements supported by missionary agents in a similar context to New Norcia. The government would have had some awareness of the 'success of the Aboriginal farming settlements, Coranderrk and Cumeroogunga' 69 .

The Lands Department and Chief Protector of Aborigines correspondence files contain examples of a pessimistic attitude to Aboriginal farming that was present in the community at this time. For example, A. R. Richardson, Commissioner of Crown Lands, wrote to the Under Secretary for Lands in 1896 when he had made the decision to cancel the reserve of an Aboriginal farmer in Katanning. 'I consider it quite useless and never likely to succeed', he wrote, 'this idea of natives or even half-castes settling or cultivating the Reserves - "it is not in them" 70 . There was an expectation that Aborigines would fail to make sufficient improvements, continuing a long-held belief that Aboriginal people

\footnotetext{
${ }^{67}$ A. Haebich: For Their Own Good, p. 28.

${ }^{68}$ Quoted in A. Haebich, For Their Own Good, pp. 28-29; for the debate see Western Australian Parliamentary Debates 11, 1886: 246, State Records Office of Western Australia.

${ }^{69}$ A. Haebich: For Their Own Good, p. 29.

70 'A. R. Richardson to Under Secretary for Lands, 26 October 1896', 1896/5926, SRO WA. Alex Richardson was a Pilbara squatter who would have had little experience of New Norcia. He probably formed his opinions about Aboriginal incapacity during his experiences of the remote Pilbara frontier.
} 
were not capable of settling and cultivating the land. When Paul Piramino, from New Norcia, applied to the Aborigines Department in 1905 to obtain a saw to use when working on his land, the Protector sent an inspector to report on the improvements Piramino had made, and afterwards concluded: 'It is as I thought - Piramino will never do much work either on his own land or anyone else's. Do not send the saw ${ }^{71}$.

Luke Mourdey, Benedict Cuper, Charles Ponan, Paul Narrier and Paul Piramino were some of the Aboriginal individuals who had land at or near New Norcia as part of these land regulations. However, lack of capital, together with the need to support their family, meant that these men had to find work to supplement their income and sometimes struggled to keep up the improvements on their farms. When their leases were cancelled they were faced with a second wave of dispossession, but they fought, sometimes successfully, to retain access to and ownership of their land. Having been removed from their traditional country decades earlier and relocated to a new country, these stories of Aboriginal farmers facing a re-dispossession are similar to the struggles for land that took place at Coranderrk Aboriginal Station. Both New Norcia and Coranderrk reveal rare examples of bureaucratic decisions against Aboriginal people being revoked due to Aboriginal and humanitarian protest.

The protests by New Norcia residents were conducted in a mode that they had developed alongside the Benedictine Brothers and which reveal the Aborigines' strong convictions of kuoba and winda, right and wrong. Richard Broome has argued persuasively that at Coranderrk the Aboriginal residents acted on their belief of what he has termed right behaviour. 'Their relationship to the natural world was governed by rich protocols and taboos and social relations were highly ritualised $[\ldots]^{772}$. Aboriginal people had laws and customary understandings about correct conduct, expressed particularly in the idioms of kinship and reciprocity'. The Kulin, Broome argues, acted on these beliefs, particularly 'with regard to issues of management and rationing'73.

\footnotetext{
${ }^{71}$ Chief Protector of Aborigines, 21 January 1905, Cons 652, SRO WA.

72 R. Broome (2006): “There were vegetables every year Mr Green was here”: Right behaviour and the struggle for autonomy at Coranderrk Aboriginal Reserve', History Australia, vol. 3, no. 2, p. 43.1.

${ }^{73}$ R. Broome (2006): “"There were vegetables every year Mr Green was here”, p. 43.2.
} 
Aboriginal people's rights and entitlements at New Norcia were expressed in writing as early as 1861 when a group of 18 Aboriginal residents signed a petition complaining that one of the Brothers at the mission had shot one of their dogs. This group knew what they were legally entitled to: 'the Government allow us natives onley one Dog to each natives'. They reported the story of their dog being shot by one of the Brothers: 'now last night your, Revs some of the Brothers shoot one of the natives Dogs through the Hart and we all things that is not good enough for us all'. This group stated their idea of what would be considered fair and just:

[...] we all natives whould have nothing to say to you you, Rev. F Betteran if the Brother that shoot the Dog at time when the Dog pat the sheep doun on the ground and trying to kill the sheep it is his Plaice to shoot the Dog because the Dog trye to kill the sheep [...] we all natives things that is a rong thing to too us poor natives some of us have got large famley and I say again that to have one Dog each marrage men withe large famley it is a good healp to us at sundays to go out to get Kangeroo or some other things in the Bush. we say again the Brother that shoot the Dog last night your, Revn.s we all thing he tone a bat thing thire was no sheep in the field and the Dog whent to have a swim and the River Brother shoot it and kill it.

The letter ended with the statement: 'We all natives hav Nomore to say tou your Revens and we all remain your Faithfull Servends' 74 . The first signature was Paul Piramino. Mary Ellen Cuper was also one of the signatories.

Other written protests concerned rations and blankets. Felix Jackimara and George Shaw, for example, both believed they were entitled to more than they were receiving, and in 1911 wrote to the Chief Protector asking for more flour and rugs ${ }^{75}$. These were important moral statements for right treatment.

In May 1907 three reserves which had been set aside for use by Aborigines were cancelled and opened for public selection, as it was thought that insufficient improvements could be shown on them. One of these blocks belonged to Charles Ponan at Catabody in Wyening. Haebich has suggested that adjoining

\footnotetext{
74 'Letter from several Aborigines to Rev Bertran', undated, 1861, NNA ACC 2224A/16.163.

75 'Letter from George Shaw to Mr Gale, 27 April 1911', Cons 652 1911/473, SRO WA; 'Letter from Felix Jackimara to Mr Gale, 27 April 1911', Cons 652, 1911/473, SRO WA.
} 
white farmers reported Ponan's lack of cultivation to the Lands Department in order to 'gain possession' of Ponan's land themselves ${ }^{76}$. Ponan protested to the acting Chief Protector of Aborigines, E. Pechelle, with the help of a neighbour who transcribed a letter for him. He argued that if he was moved off his land the government ought to pay him compensation for the improvements he had made to his country: 'I think it is not a fair thing to have me shifted out of my best ground and what labour I done in it. I hope you will see into this for me [...]. I am in my ground, I will not shift from what labour I have done in it until I hear from your reply ${ }^{37}$. Ponan described how he had 'ringed 20 acres and cleared 10 acres and got a little $1 / 2$ acre garden, sunk a tank three feet deep and two yards wide' ${ }^{78}$. His letter persuaded the Protector, and in November 1907 his block of land was again classified as a reserve for use by an Aboriginal, and he remained there. Ponan had the determination to object to the Protector about his land being taken away, and stressed his desire to retain it, fighting for what he considered to be rightfully his.

The idea of payment for the labour Ponan had done on his country had its seeds in the structure of labour and wages that Salvado set up at New Norcia, where 'to have Aboriginal men working without recompense or reward would make them feel the burden of civilisation without its advantages [...] Properly instructed the aboriginal acquires a just idea of both the value of money and property, and diligently studies thenceforth how we may better his condition'79.

Some Aborigines, such as Luke Mourdey and Benedict Cuper, applied to the Aborigines Department for assistance with farming equipment (tools, fencing wire, and corrugated iron) in developing their farms. Both received some capital assistance after a period of protracted negotiations, during which time Mourdey was nearly impoverished. Often these negotiations with the Aborigines Department were made with the help of neighbouring settlers or missionaries at New Norcia.

\footnotetext{
${ }^{76}$ A. Haebich: For Their Own Good, p. 32.

77 'Letter to E Pechell, acting Chief Protector of Aborigines, from Charles Ponan, Catabody, Monday 26 [August] 1907', ADF 1907, 357, SRO WA.

78 'Letter to E Pechell, from Charles Ponan, Monday 26 [August] 1907'.

${ }^{79}$ E. J. Stormon: The Salvado Memoirs, chapter 10.
} 
Cuper had a block at Wyening and by 1905 had fifteen acres under crop, fifty cleared and ready for ploughing and posts ready for one hundred chains of fencing. On 29 th November 1905, Cuper's local Member of Parliament, G. W. Gardiner, wrote a letter to Henry Prinsep, Chief Protector of Aborigines. Gardiner described Cuper's productivity: 'I noticed he has a good deal of improvement done - there are a good deal of posts in the ground ready for the wire - I know him to be a steady hard working man and he ought to be encouraged' ${ }^{20}$. Henry Prinsep wrote to E. Pechelle on $1^{\text {st }}$ December 1905, stating that he had spoken to Gardiner and received a letter from H. W. Phillips, a neighbour of Cuper's, also supporting Cuper, and that Cuper was 'well worthy of encouragement as he was a well conducted industrious man living on a block of land obtained from the Lands Department under their Regulations as an aboriginal'. Prinsep added that 'the man himself subsequently came to see $m e^{31}$. In his presentation to the authorities for assistance, Cuper not only wrote letters himself, he gathered a small network of powerful figures to speak on his behalf: New Norcia mission authorities, a white neighbour and his local Member of Parliament. With the help of this network, combined with Cuper's success on the land and his reputation as a steady and industrious man, he was a challenge to the expectation that some settlers had of indigenous capabilities and achievement.

The department agreed to supply his wire. On 30 December 1905 Cuper wrote to Prinsep thanking him for the wire. In this letter Cuper also reveals that he, perhaps, knew Prinsep well: he asked after Rose and Charles 'wishing them luck at school' and reminds Prinsep 'you promas me that poto' of his family ${ }^{82}$. However, Cuper was not always successful in his applications to government. In 1914 his application for the old-age pension was rejected because he came under the 1905 Aborigines Act. This created financial difficulty and he lost his land soon after ${ }^{83}$.

Luke Mourdey was granted land in 1903 but it was also cancelled and then returned to him following his written objections to the authorities ${ }^{84}$. It is worth

\footnotetext{
80 'Letter from G. W. Gardiner to H. Prinsep, 29 November 1905', Cons 255, 1907/726 SRO WA.

81 'Letter from Prinsep to E. Pechelle, 1 December 1905', Cons 255, 1907/726 SRO WA.

82 'Letter from Benedict Cuper to Henry Prinsep', Cons 255, 1907/726 SRO WA.

${ }^{83}$ A. Haebich: For Their Own Good, p. 32.

${ }^{84}$ A. Haebich: For Their Own Good, p. 384.
} 
considering the ways in which Aboriginal farmers portrayed themselves in their letters to authority. Both Mourdey and Cuper changed their surnames when writing to authorities. 'Luke Mourdey' was almost certainly an alias for Lucas Murrichery, Benedict Cuper's stepson. In all of Cuper's correspondence and contracts about his land he signed as 'Cooper'. Lucas Murrichery adopted the more English name of Luke Mourdy (also written as Moody). It is difficult to know why Cuper and Murrichery did this. It could be understood as a strategic attempt to appear less 'Aboriginal' to the authorities, emphasising their farming identity over their Aboriginal one as a way of affecting change. Interestingly, in correspondence in May 1898 between Fr Dominguez and Salvado, Salvado expressed concern about Cuper's use of 'Cooper' when he signed a legal document. Salvado 'got upset at seeing that Cuper has signed as "Cooper" (an English surname) because the Document and his marriage certificate are under "Cuper" (his Australian name), a fact that could invalidate the document' 85 . Salvado urged Dominguez to make "Cuper sign several times as Cuper so that [...] he won't make the same mistake' 86 . Salvado was clear about his encouragement of the 'Australians' to take a baptismal name as well as keeping their indigenous surname when they came to New Norcia.

While the Aboriginal 'rebellion' at Coranderrk has been well documented by historians, the instances of political traction at New Norcia, while less publicly voiced than those of Coranderrk, also reveal Aboriginal individuals identifying and claiming the rights that they believed they were entitled to. The narrative of Salvado's missionary 'success' and his enlightened approach to 'civilising' the Aboriginal people who came to New Norcia has overshadowed the story of the political agitations of some of the mission residents in the early 1900s. As this chapter has discussed, Aboriginal people's expectations, ideas of entitlement and land rights can be tracked through the New Norcia archives, in their petitions, letters and actions, and in the way they identified themselves ${ }^{87}$.

\footnotetext{
85 'Letter from Salvado (Perth) to Dominguez (New Norcia), 19 May 1898', NNA ACC 2-2234A/53.97. 86 'Letter from Salvado (Perth) to Dominguez (New Norcia), 19 May 1898', NNA ACC 2-2234A/53.99.

${ }^{87}$ The changes brought about by Torres and his successor, Dom Catalán (1916-1951), focused on monastic life and increased engagements with the local settler community. New Norcia's Aboriginal schools closed in 1971 and formal secondary education ceased with the closure of New Norcia's Catholic college in 1991. Today the town operates as a site for spiritual retreats, a tourist attraction and the Education Centre offers school programs including Aboriginal studies. In 2008 a restoration project began and the last remaining Aboriginal cottage - which had been used as a public toilet since the 1950 s - was restored.
} 


\section{CIVILISATION AND CULTURE IN ROSENDO SALVADO*}

\section{Ramón Máiz}

Universidade de Santiago de Compostela

Doi: 10.17075/rsmaa.2016.en.011

* The author wants to manifest his gratitude to Anna Haebich, Tim Rowse, Tiffany Shellam and the archivists of New Norcia, Western Australia, without whose generous help this research would not have been possible. 


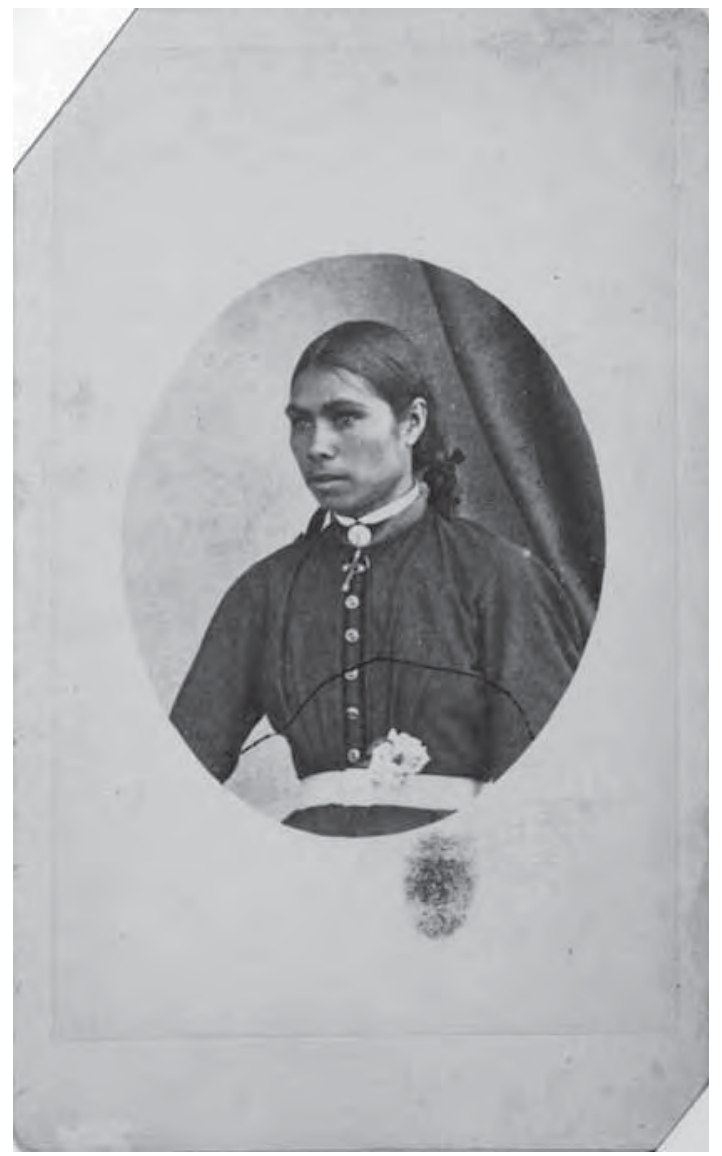


'What was there after all? Joy, fear, sorrow, devotion, valour, rage — who can tell? — but truth — truth stripped of its cloak of time.' Joseph Conrad, Heart of Darkness

The purpose of my intervention is to attempt a reconstruction of the main elements of the philosophy of civilisation in Rosendo Salvado's thought which emerged, most often in a practical form, over the course of his work with Western Australian Aborigines. We will maintain in these pages that, as theoretical foundation of New Norcia, there was an elaborate formulation in Salvado's contact, evangelisation and acculturation of Aborigines, one that went beyond merely practical, impromptu, vaguely humanitarian knowledge. In fact, beneath his exceptional project, we can catch a glimpse of a 'theory' that diverges critically - 'in my own way' - and systematically from each and every one of the most important assumptions and arguments that historically served to legitimise ethnic cleansing, genocide, racism, colonisation and even assimilationism in the $19^{\text {th }}$ and $20^{\text {th }}$ centuries. In short, a vision ever-present in his career and fragmentarily expounded in his writings that, very distinctly, challenges and leaves the mental horizon of the colonialist world behind, always swimming against the tide of 'Evangelists of Empire'.

Salvado's own words speak quite eloquently about his self-awareness as he developed, based on his experiences, his own ideas and principles, which would be the foundation of the 'Salvado method', the 'New Norcia exception' that would be recognised by Florence Nightingale from the metropolis (Shellam, 2012a). In effect, Salvado wrote in his text 'Information respecting the aboriginal natives of Western Australia', addressed to the colonial secretary:

To this hypothesis it may be said that after all there is more in it than a theory—indeed it is a theory [...]. Anyhow, that theory has regulated my operations here, and that 
hypothesis is nothing else but the same theory put here into practice in order to attain our charitable and heartily wished-for end, viz., the conversion and civilization of the aborigines of the province. (Salvado, 1864: 6-7)

We will argue in the following pages that, firstly, this theory did not emerge at once; on the contrary, it was the contingent result of a hard, long process of learning, trial and error, and cultural conflicts and negotiations with Yuin Aborigines. The turning point of this process came with the failure of the 'great experiment': the death of the Aboriginal boys sent to Europe to receive a religious education. In spite of the fact that some have interpreted this episode as the origin of the failure of the Benedictine monk's entire project (Ride, 2007), Salvado drew decisive conclusions from it for his subsequent civilisatory method.

Secondly, we will maintain that the 'Salvado hypothesis', even within the limits of his civilisatory and missionary horizon, is radically different from other colonial enterprises of the time, with which it can in no way be equated. Let alone reduced to 'the unjustified removal of Indigenous children, perhaps the first example of systematised removal in Australia's history' (Hills, 2008: 156). In fact, as we will soon see, many of Salvado's contributions are now commonplace in recent paradigms of recognition, cultural pluralism and multiculturalism, one and a half centuries later.

Thirdly, we will show that the abbot's vision includes a wealth of extraordinarily complex issues, perspectives, arguments, practices and institutional designs. To our mind, it was especially around the creative conceptual tension - always open and unresolved, even impossible to dispel between civilisation and culture that Salvado articulated other tensions such as population/people, autonomy/authenticity, morality/ethicality, universalism/ particularism, artificiality/nature, etc., which constitute the core of his, for so many reasons, unique contribution.

We speak of unresolved tension because the linchpin of Salvado's method lies precisely in the avoidance of two oversimplifying extremes. One is the prevailing colonialist thesis of the indisputable superiority of Western civilisation and the consequent contempt for indigenous cultures, considered as inferior, not fit for civilisation and even doomed to extinction (the 'doomed race theory'). The second extreme is the thesis of acritical immersion in cultural particularism, the 
appreciation of difference qua difference and the resulting application of standards that are exclusive to the Aboriginal world, failing to critically examine the relations of power, submission and exploitation that exist (also) in minority cultures, in their traditions and institutions (oppression, gerontocracy, patriarchalism, etc.).

Let us examine, then - there is no option but simplify here - some of the elements of the semantic and conceptual network of oppositions and associations that make up the intellectual mould in which Salvado's innovative vision was built.

1) The first tension that runs along Salvado's entire life is, since he was a missionary, that of religion/secularisation. There is something quite remarkable about somebody as deeply Christian as he was, somebody who devoted his entire life (from 1846 to 1903) (Russo, 1980; Linage, 1999; Prada, 2014) to the hardest Catholic commitment that one could imagine at that time: the evangelisation of the natives in the Antipodes - rejecting in 1852 a tempting offer from the episcopal see of Lugo: 'I prefer souls to revenues. I am leaving for Australia.' What is remarkable, as we were saying, is the peculiar secularism of his approach to evangelisation and civilisation work.

On the one hand, we should highlight the fact that Salvado's choice of community was not obvious at all, as well as the fact that he devoted his efforts to Australian Aborigines, considered as a race lost to the cause of civilisation and Christianity (Prada, 2014: 10-28), perceived by colonists and Protestant churches as a degraded, inferior race that was doomed to extinction - instead of devoting such efforts to whites, as was usually done in Australia in the $19^{\text {th }}$ century. In effect, in his own words,

In Australia, the Europeans absorb all of missionaries' minds, all of their time, all of their means, and the poor savages remain entirely abandoned and forgotten [...]. Everything, absolutely everything is done for the Europeans; nothing, absolutely nothing for the savages. (Salvado, 1883: 432)

From that very initial choice of the community to be evangelised, one that was despised and rejected by all, to his methods - nomadic at first, and later implemented through the establishment of the mission - Salvado was well aware 
that New Norcia was 'a rare exception', always swimming against the tide of colonists, Protestants and even his Church itself:

Conviene ricordarsi che né il vescovo, né il clero, né i cattolici della Diocesi di Perth contribuirono giammai con un soldo in pro della Missione de Nuova Norcia, e che per il contrario, el Santo padre Pio IX, ebbe a concedere una sanatoria al Diocesano di Perth per 10.000 libre spesi in pro degli europei invece de spenderli in pro degl'indigeni o selvaggi a cui appartenevano. (Salvado, 1883: 402)

However, very significantly, there is no fundamentalism in his actions. There is an unusual secular, even materialistic (if we are allowed to use this expression) side to Salvado's evangelising and spiritual work, based on his loyalty to his values and principles - a side that made him consider Aborigines' physical wellbeing, bodies, diet and health as a priority over the salvation of their souls:

It is necessary to tend to Aborigines' spiritual and temporal interests at the same time; hence the need that the mission be provided with as many material goods as possible, not for its own enrichment but for supplying each savage family that, abandoning its nomadic, leisure life, wishes to settle in a given place with everything such family needs. (Salvado, 1852: 307)

His dedication to the natives' health, his search for a cure for their most common diseases, earned Salvado the name of 'Bolya Gumbar', the 'great doctor' (Shellam, 2012a: 114). The attention he most originally paid to physical exercise outdoors, farm work, the hygiene of the mission's premises (the light, temperature and ventilation of the rooms and so on), his respect for native gathering and hunting activities in the wilderness, were all along these lines.

Moreover, Salvado believed that Aborigines' welfare did not depend as much on their prompt conversion as on the family, economic and social structures in which they lived their lives. In this context, and quite surprisingly for his contemporaries, Salvado chose to give priority to manual work over intellectual work, to health care and a healthy diet; to physical exercise outdoors over the spiritual food of doctrine. It is even very interesting to see how manual work, 'the physical exercise system', had to take priority, in his view, over the obsession 
of 'ONLY [underlined in the original] teaching them to read and write' (Salvado, 1864: 7).

There is nothing more significant for these purposes than our Benedictine's febrile search for and research on the causes of mortality among the natives. Far from attributing such an extraordinary death rate to the supposedly declining, inferior nature of their race, or to God's inscrutable ways, with racist fatalism and pessimism, such a mortality rate was, to his mind, due to very specific reasons: 'white man's disease, arsenic poisoning, and murderous shooting' (Salvado, 1852 [1946]: 351). To this we must add his diagnosis of the causes of indigenous vulnerability, which did not lay, for Salvado, in their deficient physiology, but in the wrong 'civilisatory' methods employed by colonial governments and churches.

Even Salvado's thorough demographic and statistical exploration of the Aboriginal 'population' owes much to this material attention to ways of life, diet, habits, traditions and habitat, as well as the effects of systematic racist ethnic cleansing and genocide - racist 'clearing', to use Anna Haebich's words (Haebich, 2004) - inflicted by white colonists and farmers (Moses, 2004; Maddison, 2011).

2) The second tension we can discern in Salvado's career, and to which we should pay special attention, is that of reason/sensitivity. Contrary to the theories in vogue at that time about Aborigines' bleak future - whether social Darwinist theses that declared them unfit for civilisation or the assumption that they were godforsaken people, which rendered any efforts to evangelise them useless Salvado cultivated unprejudiced knowledge based on the empirical observation of facts through his contact with the natives and his actual, respectful life among them - 'an Aborigine with Aborigines,' as Giulio Cipollone has very aptly highlighted. Cipollone has stressed Salvado's egalitarian approach to Aborigines, something highly unusual in the racist context of the time and which became apparent, little by little, as Salvado ceased to consider them savages, engaging in increasingly personalised and close relationships with them, making use of proper names, of expressions of friendship: 'my friend and loyal companion' (Cipollone, 2011: 213). Against the ideological prejudices of racism and colonialism, Salvado gave precedence to direct contact, to thorough, respectful observation, experimentation, the trial-and-error approach, and always paid 
attention to what facts said. For it was his belief that 'against the force of facts, no argument may hold,' and hence his categorical conclusion: 'Voler negare loro la capacitá della educazione intelletuale, sarebbe los stesso que voler negare al fuoco la propietà di riscaldare e di bruciare' (Salvado, 1883: 340). Such was Salvado's knowledge of Aborigines: local knowledge, i.e., site-specific knowledge resulting from everyday observation as a participant; embodied reason, against the tide of enlightened universal reason, and therefore a decisive factor to win Aborigines' trust.

But in spite of his insatiable curiosity - from natural history through the colonisation process to anthropology - to which his Historical Memoirs of Australia... bear witness, it was not all about knowledge in our Benedictine monk. His sense of music found continuation in his extraordinary human sensitivity and his great capacity for empathy with the Other. As a biographer of Salvado, Russo, has noted, his predisposition to earn Aborigines' closeness, friendship and trust was remarkable (Russo, 1980: 126) and a quality that, added to their great ideological differences, separated him from the 'cold rationality' of the very traditionalist Serra, his initial partner in missionary misfortune (Russo, 1980: 52).

That was a rare synthesis of reason and sensitivity. Conceived much as a town, one might say, a genuine town in New Norcia's wilderness, the striking, meticulous rational design of the mission's structure cannot conceal the care, the exquisite sensitivity that Salvado deployed in his relationships with Aborigines, his admiration for and open appreciation of their valour, intelligence, culture (rites, music, dance, tattoos, ceremonies), his astonished discovery of their ability to live with dignity in a hostile environment. Let us recall, for example, the abbot's learning of the Yuit language, his painstaking attention to its dialectal varieties, and even his enthusiastic assessment: 'There is nothing rough or guttural about the Australian language [...]; on the contrary, it has many grave, sonorous sounds, like the most harmonious ones in Spanish, and supple sweet-sounding ones, like the most attractive in Italian' (Salvado, 1852: 365).

3) The third tension that we would like to discuss is closely linked to the one described above, but has special prominence in Salvado's writings. We are talking about the interests/emotions dichotomy. It is noteworthy that one of the main civilisatory mechanisms that Salvado postulated theoretically, and applied 
practically, was the concept of self-interest, interest in oneself. This means that, as an indispensable basis for their autonomy and freedom, Aborigines should not simply devote some time to farm work, as we will later examine; to the abbot's mind, they also had to have an array of positive, material, selective incentives to make with dignity the effort that such work required and was so alien to their ancestral habits. That was the role played by self-interest which he praised in his Historical Memoirs of Australia...:

One of the main motives of human actions, perhaps the most important of all - interest! Try this properly, and you will see that Australians do not only work for their own benefit, as all civilised peoples in the world, but they also possess the capacity and the talent that they are so undeservingly denied. (Salvado, 1852: 353)

A few years later, in the Information... of 1864, he insisted on this aspect again: 'Self interest is the oil that makes every wheel go; take away self interest and not one will move, for nothing is done for nothing' (Salvado, 1864: 7). This is why the natives had to receive the just fruit of their farm work as an incentive to their efforts, learning and improvement. According to this peculiar enlightened, utilitarian philosophy, interest is an element that Salvado considered the basis for the natives' autonomy and freedom. And so he acted ahead of Australian Aborigines in their claim for fair remuneration -'equal pay' - for their work, which, together with their rights as original owners of the land, the natives would demand for many years (Kirby in Maddison, 2011: x). Farming the land of the mission's plots provided both the financial incentive of receiving a salary and the moral incentive of laying the foundations of self-respect and dignity, which worked against a potential inferiority complex in relation to whites. There were also the social stability and the feeling of belonging, on an equal footing, to a community in which friars and natives shared trades, work and results (Russo, 1980: 125). Eventually, farm work would even become a basis for New Norcia Aborigines' social and political claims for land rights (Shellam, 2014).

But, at the same time, one must not fail to notice the fine emotional dimension, the cultivation of empathy, of the ability to walk in others' shoes, the physical and psychological care, the affection that emerges from Salvado's 
enormous efforts and is reflected in his memoirs: esteem, affection, endless patience. The assessment of how Aborigines were treated, as stated in Salvado's reports, is important in this connexion, especially in contrast to Protestant missions. While natives came voluntarily to New Norcia and were totally free to stay there - they could leave and come back, even be visited by their relatives, live in cottages designed for large households, take holidays, etc. - Protestant missions were places to which they were, most often, taken by force, and there were multiple attempted escapes after which the natives were taken back there, almost always violently and handcuffed ('con le manette di ferro ai polsi' [Salvado, 1883: 309]).

4) Another tension that springs in Salvado's work and reflexions over and over again is that involving artificiality and naturalness. Civilisation required that the natives abandon their natural state, i.e., that they give up their traditional nomadic life in the wilderness, where they often fell victim to the ethnic cleansing or genocide inflicted by colonists and white authorities. In spite of this, however, respect for nature, for Aborigines' constituent relationship with their environment, became a capital dimension of Salvado's method. On the one hand, Salvado designed New Norcia's civilisatory artifice; he paid careful attention to the internal structure and the layout of the mission's buildings, where the natives' dwellings should follow the structure of divided, multi-level family houses, based on the Rule of St Benedict (and perhaps, one might hypothesise, even inspired by Jesuit reductions in Latin America).

We must stress this plural dimension of institutional design and innovation in the segregated, self-supporting world of the mission, which was ever-present in Salvado's efforts: the classrooms for students, the rooms-bedrooms for families, the organisation of the farms, intended for crops and cattle, the library (for which Salvado travelled across Europe gathering books), the chapel, etc. This institutional innovation was designed with a major goal in mind: the everyday coexistence of monks and natives, and their joint execution of manual work.

On the other hand, however, this partial segregation of Aborigines in the sphere of the mission, as it had been conceived, was not intended only to protect the natives from any contact with European colonists. As Russo has pointed out, Salvado 
did realize that the maintenance of an interest in their tribal territory was essential for social stability. Fearing that a too sudden disintegration of their old ways would prevent them from ever assimilating properly to European culture, he aimed at segregation for at least a period of adjustment. (Russo, 1980: 136)

With regard to the tension we are dealing with, artifice/nature, this dichotomy - congenital in Salvado - can be shown in relation to a second, though implicit, double linchpin, which is that of land/territory. Let us explore it briefly. 'Land' refers to earth considered in its dimension of use, work and securement of individual sustenance, i.e., farm work that reinforced self-interest and provided the basis for the natives' self-ownership, as well as the ownership of and benefit from the products obtained through their hard work in New Norcia's estate. Each family had its own plot, which was not only the fundamental pillar of their autonomous entry into a productive economy but, beyond that merely financial dimension, the genuine foundation of self-respect, personal self-determination, freedom, wellbeing, but also responsibility. At the same time, the earth is more than land intended to be exploited through work: it becomes a territory, i.e., the natural, physical basis of the community, its landscape, its ecological niche, contact with nature as the basis for Aborigines' culture, religion, practices, institutions, art, way of life. Hence Salvado's bright idea of combining both of its dimensions, land/territory, at all times: farming the land while maintaining traditional, communal relationships with the territory. Against the devastating effects of an education conducted exclusively behind closed doors, of excessive 'indoor restraint', as a central part of his method Salvado always insisted on going out in the open air, on the possibility for the natives to have at least three weeks off to wander in the bush, the natural environment of community life, the loss of which would do the natives actual harm.

Salvado worried for years about what might be the reason for the death of a number of natives. The mortality rate could apparently not be explained by the presence of any physical condition, as the natives certainly recovered soon from serious injuries associated with hunting or fighting. Salvado eventually found out that he was dealing with a special kind of spiritual illness: nostalgia, 'homesickness', to use the same English term as him (Salvado, 1862: 4), which was 
caused by the natives' loss of the communal territory that was their reference. Strictly speaking, by the fact that they had been deprived of their natural environment.

Salvado had to strike a difficult balance between the stable settlement of nomadic populations in the mission and the preservation of the essential traits of their culture, which owed a great deal to the natural backdrop. He did so by establishing porous borders between the mission and the surrounding wilderness, between the land intended for farm work and the territory as natural substrate of Aboriginal communities and their culture. And in doing so Salvado did not only combine the civilisatory artifice and the pristine nature of the wilderness, but also the capital ethical dimensions of autonomy and authenticity. In Salvado's project, Aborigines' personal autonomy as free individuals whose paid work gave them a sense of self-respect was complemented, at all times, with the attention he paid to authenticity, i.e., Aborigines' ability to remain loyal to their culture and community, which included a relationship of direct communication with nature. Such nature was, in all other respects, not Arcadian, reconciled with them, benevolent, but harsh and extreme, threatening, and still a genuine 'motherland' for the natives, whose loss resulted in homesickness or even Heimatlosigkeit, a feeling of irreparable loss of the homeland where one's origins were.

5) Sciencelart. This is a central tension in Salvado's multiple-sided vision. A tension between science and art that we may define as the rich, simultaneous presence of two very distant worlds in our Benedictine: statistics and music. In effect, on the one hand, it is surprising - although consistent with his empirical attention to 'facts', as was already discussed above - how familiar Salvado was with social statistics, a discipline that was barely emerging at that point of the $19^{\text {th }}$ century. In this regard, an extremely interesting episode was his exchange of data and correspondence with Florence Nightingale, following the colonial survey conducted in 1860 by this exceptional woman, a nurse, a pioneer of hygiene and public health, a forerunner of statistics in social sciences and, ultimately, a feminist (McDonald, 2010).

As is well known, Nightingale's project involved the conduct of a survey (the so-called survey method) on the health, mortality and schooling conditions of indigenous boys and girls in the British Empire. Salvado, who had been 
compiling data on the Aboriginal population since the 1850 s, received a questionnaire pertaining to this survey, which he answered with great precision and even developing and explaining certain aspects of his 'method'. Rowse and Shellam have studied these aspects in depth, and I refer the reader to their contributions (Rowse and Shellam, 2013). Nevertheless, we should highlight the remarkable fact that Nightingale considered New Norcia as a proud 'exception' that showed, in her opinion, that, contrary to what had been done until then, the British Empire could civilise Aborigines without exterminating them, provided, however, that the procedures followed so far changed radically. This would imply, specifically, the adoption of a process of gradual education and systematic physical exercise. Nightingale coincided with Salvado in two aspects: 1) in his scientific trust in social statistics as the indisputable evidence of facts against the racist prejudices of the ideology of colonialism (health, causes of death, the doomed race theory, etc.), and 2) in an educational method based on the priority given to physical training, against the restraint of students in educational centres and their compulsive religious education, focused on reading and writing skills. In fact, when Nightingale presented her lecture ('Note on the aboriginal races of Australia') at the annual meeting of the National Association for the Promotion of Social Sciences in 1864, she included a long quote of Salvado's report (Rowse and Shellam, 2013: 25).

But, at the same time, Salvado paid extraordinary attention to Aboriginal arts: music, paintings, adornments, tattoos, poetry, dances, etc. were worthy of his careful attention and respect, and he devoted much of his time to observe and learn the different expressions of such arts. With regard to music, this was a discipline that, as is well known, played a central role in Salvado's life; for he was a pianist, an organist and a composer. It is astonishing how he was able to combine the cultivation of Western religious music with the respectful learning, study and use of traditional indigenous music. He did not, however, make an instrumental use of their music for the purposes of evangelisation, but truly recognised the musical value of Aboriginal chants and dances, which translated into open admiration:

Australian music has a beautiful, amusing side, like Phoenician music, and a grave, serious side, like Dorian music [...]. How many times have I used their dance songs to 
give them encouragement and strength during their work in the fields? [...] When they heard me sing Maquielo, which is one of the most favourite, common songs, they would stand up as if moved by an irresistible force [...]. (Salvado, 1852: 368)

6) And so we have reached the core of Salvado's vision: the decisive creative civilisation/culture tension. On the one hand, Salvado's project owed much to two fundamental intentions on which universality should be built: the idea of civilisation ('to civilise Aborigines') and the Catholic idea of religion ('to evangelise Aborigines'). On the other hand, these universalist dimensions did not result, in the case of the Galician Benedictine, in the assumption of ethnocentric or ethnocratic premises, such as racism, cultural superiority, contempt for the other, the 'dying race' discourse that prevailed in the Australia of the time, the discourse on the natives' congenital lack of capacity for civilisation or even Christianisation; ultimately, the discourse on their inevitable extinction.

The reason why Salvado's vision followed other paths, against the tide of the prevailing ideas, should be sought in the fact that Salvado's aim of universality, which he was not willing to give up, was greatly qualified by his love and recognisance of the endless plurality of non-Western culture, by his unprejudiced respect for the contributions that resulted from the existence of particularities. For Salvado, as can be read in his writings, every human being, every group in humanity, had its own standards, its specific world of meaning. And civilisation should proceed by making a reading of the universal values of science and religion without destroying peoples' cultural richness. Nightingale herself had warned repeatedly and very clearly about the dangers of the 'civilisation' imposed by the Empire: '[W]e and our civilization seem likely to cause the extinction of whole races and tribes' (McDonald, 2010: 172).

Indeed, Salvado took very seriously the capital question that Nightingale addressed to the British Empire, causing a great scandal. In his own words, 'Florence Nightingale's question - 'Can we civilize the Aborigines without killing them?' - is not a simple issue, but a difficult problem that God knows when will be solved' (Salvado, 1864: 4). The radical criticism of racism - i.e., the transposition of the cultural, intellectual and spiritual form to the somatic form - expounded by Salvado in his writings, particularly in his Historical 
Memoirs of Australia..., leaves no room for doubt and stands as the cornerstone of his entire project:

The physical and moral character of the Australian has been painted with such false colours, that most people judge him to be the most degraded individual of the human species. He is generally considered to be rickety and misshaped, very similar to brutes themselves, and some go as far as claiming that there is not the slightest difference between an Australian and an orangutan. Some, and not just one, but many, have even denied that the Australian native is endowed with a rational soul. (Salvado, 1852: 345)

We insisted above that, all things being equal, Salvado's exceptional civilisatory method gave priority to health, sanitation, diet, physical exercise and farm work; now we need to add another, not less important characteristic. His method articulated the contributions of Western education with ample room for the cultivation and development of cultural practices by Aborigines (music, dance, hunting, etc.). Rejecting ethnocentric prejudices was, therefore, an outstanding characteristic of his vision:

We ought to bear in mind that the Aborigines are exotic or foreigners to our civilization. They cannot stand, at once, not even our food, much less our daily hard work, let it be mental or physical [...]. We look at them with European eyes, consider them as Europeans, and try to train them as such; but in doing so we delude ourselves. Their case is quite another, quite different from ours, and we ought to bring them to our case and high position, not at once, but by the same way we came to it, by degrees. (Salvado, 1864: 5)

'By degrees': this was, for Salvado's method, the key consequence of the abandonment of Eurocentrism. It meant avoiding the imposition of the European model on Aborigines and making a bid for a progressive approach, for a gradual, self-correcting civilisatory process, based on dialogical respect and the recognition of the value of Aboriginal culture. In one of his answers to Nightingale's questionnaire, Salvado insisted and laid extreme emphasis on the devastating effects of the classic civilisatory model: '[I]t will be found that the idea of bringin $[s i c]$ savages from their wild state, at once to an advanced 
civilisation serves no other purpose than that of murdering them.' As LéviStrauss and other anthropologists such as Geertz would find out, much later, Salvado seemed to glimpse that human societies are never alone; when they most seem to be separated, we discover that they form groups that maintain close contacts. And, in addition to any differences due to isolation, there are others, also important, due to closeness: the wish to stand in contrast with the rest, to stand out, to develop a personality of one's own and so on, to the extent that diversity is less due to isolation than to the relationships that bring us together. In Salvado's dialogical perspective, it is by no means negligible to see that in the process of evangelisation he resorted to indigenous mythology, whose complexity he came to know only after many efforts made over time, and he did so in order to build bridges, similarities and differences in relation to the Catholic religion (Russo, 1980: 163).

In sum, the civilisation/culture tension brings a contingent relationship to the surface, one that is yet to be explored and involves local dimensions, of great ethical force, and universal dimensions that are more restricted and open to interpretation. This is, following Walzer, thick-and-thin dialectic between values that are common to humanity as a whole and values and traditions that are specific to Yuit culture. And Salvado felt that 1) the universal dimension of Catholicity did not invalidate the fact that each person and each people should have their own yardsticks; 2) collective identity was defined as a shared world of attributed meaning and was greatly valuable for Aborigines; its erosion or loss would do them irreparable harm; 3) against the thesis that defended the superiority of Western culture, Salvado postulated the equal dignity of all cultures and their ability to critically examine their own practices, institutions and traditions; 4) recognition played a constituent role in the natives' collective identity, both in a positive sense (respect for their differentiated dignity) and in a negative sense (racist, stereotyped inferiority); 5) lastly, the translation of all of the above is that for Salvado, against derogatory colonialist prejudices, Aborigines stood as genuine 'signifying Others', as this expression was used by Mead; i.e., as participants in the dialogical process of construction of a specific version of civilisation, one that was filtered through and adapted by Aboriginal culture.

This greater civilisation/culture tension, which finds continuation in the universalism/particularism tension, is expanded as an additional revision of the 
tissue of moral values and principles at stake, informed by the morality/ethicality dualism. Such morality referring, specifically, to Christian values in the broad sense of the word, which Salvado postulates from universal humanitarian foundations (equal dignity and value of human life, the common heritage of freedom). This is presented with respect but also in a manner that is critical with the ethicality, the communal values of Aboriginal culture.

Nowhere as in women's social status can we find more clearly this tension between civilisation and culture, between morality and ethicality, that we are exploring. In effect, Salvado saw, first and foremost, how complex the social status of Yuit women was. While they enjoyed relative independence (having rites of their own from which men were excluded, the possibility to reach the position of shaman, the ability to engage in 'male' activities such as hunting, etc.), they were also victims of systematic gender violence since they were very young, they experienced a great loss of independence and freedom and were subjected to exchanges of favours, social marginalisation, abandonment and death. Through the civilisation/culture tension described above, Salvado attempted at all times to reverse the subordination, exploitation and systematic oppression of Aboriginal women which were etched in century-old traditions; and he did so by guaranteeing the same level of education and training for women as for men.

There were few things Salvado was prouder of than the educational process of Ellen Cuper, who, after her training at the mission, was appointed postmistress and official telegraphist of the New Norcia station. Salvado wrote enthusiastically in his Relazione: 'Not even in my wildest dreams had I imagined that I would see in 1874, that is, 28 years later, telegraphic communication established in that region, and the postal service officially in charge and under the direction of an indigenous woman' (Salvado, 1883: 122). Not less important was the fact that this was not an exception, as Mrs Cuper was followed by another two indigenous women as postmistresses: Sarah Curningun and Carmine Guarbak (Cipollone, 2011: 208).

7) All that has been examined so far leads us to the last and greatest tension in the theory and practices of the abbot of the wilderness: population/people. However, we should stop briefly to consider an initial, previous tension: individual/community. In effect, Salvado believed that the construction of 
Aborigines as individuals in the new world of civilisation took place, as we have seen, through paid farm work and the cultivation of self-interest-related incentives that were the basis of their self-respect as masters of their destiny, their autonomy, their personal self-determination. Notwithstanding this, Aboriginal individuals were not isolated, solipsistic monads focused exclusively on the maximisation of their self-interest. On the contrary, they were inserted in the indigenous community itself, which constituted a valuable tissue of cultural practices, traditions, rituals and values that gave meaning to their lives.

Accordingly, one should notice that the individual autonomy of indigenous men and women was built, for Salvado, through the provision of material and moral resources that could lay the foundations of their freedom, their life project; in sum, the ability for each person to set their own goals for themselves. But in addition, as we have already highlighted, it is authenticity (i.e., their loyalty to difference and their active, creative respect for their culture) that constituted the basis for their communal dignity. As we will soon see, this is where a double, capital difference emerges in relation to the standard model of Protestant missions. As far as the individual was concerned, the aim was not, for Salvado, to provide a group of passive Aborigines with some resources as one waited for their inevitable fate of decline and disappearance. On the contrary, Salvado envisaged a process of active education and training, having a new vision of Aborigines on the horizon, one that was based on freedom, on personal self-determination. The mainstay of this vision would be their ability to earn their living by themselves and also to take responsibility for their own lives, and therefore their future ability to participate in the financial and political decisions of the mission and beyond. For Salvado, education in the sphere of New Norcia was not for Aborigines but with Aborigines, which clashed with the racist equation advocated by Australian nationalism and its national white fantasy according to which state $=$ nation $=$ white race $=$ citizenry . For the Benedictine monk, the Aboriginal individual was actually the embryo of a citizen empowered with rights and having his or her own voice as well as community support.

Having said this, all of the tensions explored above take us to another, certainly not unimportant tension: that between the consideration of Aborigines as a population and the alternative conception of Aborigines as a people. In effect, 
if we examine any of the above dimensions (community, culture, territory, etc.) closely, we will see how, from beneath the consideration of the natives as a population, there emerges a vision (superimposed on, but not superseding such consideration) of Aborigines as an ethnic group, as indigenous peoples.

Apart from the colonisation, the process of construction of the Australian nation as a white, Protestant, English-speaking nation had left Aborigines as a precarious minority since the Australian independence in 1872, both from a political, social and cultural point of view and in demographic terms. The people/population dichotomy is especially important in this connexion owing to the different objectives, processes and outcomes for the natives that resulted from such dichotomy (Rowse, 2012). On the international plane, this duality is well known and accepted today as a result of the changes in the ILO since the adoption of Convention No. 107, 1957 ('Indigenous and Tribal Populations') until the critical turn brought about by the highly influential Convention No. 169, 1989 ('On Indigenous and Tribal Peoples').

Indeed, the statistical knowledge gathered by Salvado and Nightingale on the causes of death and disease among Aborigines suggests that Indigenous Australians should be considered a specific population, one whose characteristics differ from those of the hegemonic white population. In this connexion, the painstaking statistical work carried out by our Benedictine compiles several years' worth of information about the Aboriginal families of the region. But what began as mere accounting work about the natives found continuation in the compilation of complex series of families and family networks, the study of dialectal varieties, the recurrence of the most common diseases, the main causes of death, the school results of native boys and girls and many others.

However, leaving demographic criteria aside, and beyond the idea of an Aboriginal population, the tensions explored above - particularly that between civilisation and culture - led to the emergence of Salvado's implicit consideration of Yuit natives as a people. In other words, as a unique, differentiated cultural ethnic group, considered as a 'signifying Other' with whom the civilisatory dialogue was initiated from a position of respect, recognition and participation.

But this step has extraordinary consequences, since the differences between both considerations are deep. For the purposes relevant to this paper, the main differences may be summarised as follows: 
1) Populations, mere aggregates of separate individuals, may disappear as a result of their integration and dissolution into a majority population, influenced by their collective statistical invisibility. Haebich calls this 'extermination by neglect' (Haebich, 2000: 208; 2004: 279). The concept of people, much unlike that of population, suggests a collective identity that is here to stay and intends to become a stable partner within the state (Rowse, 2012: 10).

2) Treating an ethnic group as a mere population facilitates the implementation of policies that, considering such group as 'inferior' or 'unfit' for civilisation, usually dictate the disappearance, extinction, degeneration, etc. of such ethnic group. This results in a loss of moral value, self-respect and dignity. Neglected by the public authorities, which do not take any steps in relation to their illnesses, diet, ways of life, etc., these populations are next subjected to different measures of ethnic cleansing and others. In contrast, peoples have collective identities and the right to recognition and development, protection, food sovereignty and equal dignity, as well as the right to a provision of resources that lay the foundations for equal opportunities.

3) Populations are units of measurement that atomise the group into a set of isolated, rootless, acculturated individuals, which are, strictly speaking, made invisible in their difference: cultural, linguistic, historical difference and so on. Peoples are presumed to have diacritical traits that make up a collective identity: a history, a language, their own ethnicity (myths, symbols, ceremonies, self-interpretation narratives, demarcation criteria for us/them, ours/theirs). We should notice that the individualistic atomisation that is typical of populations deprives ethnic groups of the support of communal solidarity that is indispensable for collective action (indigenist associations and social movements).

4) Populations inhabit a temporary, contingent, provisional space, which is not considered as a territory of their own, their habitat or the historic environment in which the community develops. Therefore, they may be displaced or re-placed by the State or the markets ('voting with the feet').

5) Considering the natives exclusively as populations makes the rights to selfgovernment and collective self-determination, as well as their respect for 
their own legal traditions and institutions (common law, legal pluralism), dysfunctional. What is appropriate for peoples is to have self-reflective capacity of adaptation through the exercise of self-government and democratic self-determination.

In sum, treating Aborigines exclusively as a population destroys their entity as a separate people having 1) specific, substantive identity traits: traditions, history, identity, cultural, religious and linguistic rights, 2) a right to title over the land in their ancestral territories, 3) rights to self-determination and selfgovernment. In other words, the 'indigenous population' discourse, much like the discourse according to which the nations inside plurinational states are 'provinces' or 'regions', has perverse performative efficacy: calling for their invisibility, this discourse erodes the specific difference of ethnic groups. In this regard, the social geographer John Taylor has noted, for example, that the development of Australia's population censuses implied the imposition of a cultural model typical of the white majority which distorted the Indigenous reality. By way of an example, this included the idea that the notion of household should comprise four dimensions: cohabitation, dining together, family relationships and domestic economy, which are often dissociated in Aboriginal communities (Rowse, 2012: 124).

Lastly, exploring the semantic and conceptual network of associations and oppositions in Salvado's thoughts leaves us in a position to give a full account of the deep resignation of Aborigines as a people and a culture, and to highlight their exceptional contribution not only in the colonial context of the $19^{\text {th }}$ century but also as an anticipation of some of the achievements made by Aboriginal peoples which would still have to wait until the late $20^{\text {th }}$ century.

If we look at the stages of the history of public policies for Aborigines in Australia (McGregor, 1997; Coopes 2010), Salvado certainly swam against the tide to begin his work in the final stage of the contact-and-conflict period (I) in the mid- $19^{\text {th }}$ century, which was characterised by the physical extermination inflicted by white colonisers carrying modern weapons, and the symbolic violence spread through the discourse of the inferiority, degradation and extinction of the Aboriginal race. But even in the following period, called the protection period (II), which covered the early years of the mission during Salvado's life (1846-1903), the belief that the inferiority of the Aboriginal race 
would, sooner or later, imply their disappearance persisted (Maddison, 2011: 51). In consequence, many of the missions and, therefore, Indigenous Australian reserves were conceived as places intended to provide precarious protection while the process of extinction lasted; at the same time, they facilitated the appropriation of Aboriginal lands, considered res nullius, by white colonists. As we have seen, Salvado challenged, one after another, the characteristics shared by most Australian reserves and missions of the time: 1) the marginalisation of Aborigines from participation in the economy, 2) linguistic contempt and the mixture of different language groups with a view to breaking their social cohesion and any potential collective action that the natives might undertake, 3) open legal discrimination, which generated a inferior status for the natives, 4) eradication of Aboriginal culture, language (imposition of the English language) and religions, and forced Christianisation.

In a radically different way, Salvado's method translated into a self-critical civilisatory process characterised by 1 ) the integration and training of Aborigines in the sphere of farm work and the country's economy, 2) the cultivation of their personal self-determination, 3) respect for and recognition of their culture. In sum, a vision of Aborigines as protagonists - from the platform of their own cultural difference immersed in a process of adaptation to the new world - of an incipient process of autonomy and self-government. We should remember that, even in the late period called that of assimilation (III) (from 1951 on) (Haebich, 2008; Elder, 2009), the fact that the Australian government abandoned the idea of Aborigines' extinction still translated into policies that called for the authoritarian socialisation of indigenous peoples and their absorption into the dominant white culture (to 'merge them into the white community'). Only later, in the reconciliation periods (IV) of the 90s, would the recognition of the existence of the Stolen Generation and, finally, the apologies of Prime Minister Kevin Rudd in 2008 serve to substantially change Australia's indigenist policies.

Salvado's work, against the tide of most 'Evangelists of Empire' and his own church, was ultimately an exceptional experience of intercultural dialogue and recognition of Aborigines in the colonial world, an experience that was not without limitations, conflicts and difficulties, an attempt as uncommon as admirable, to use Tiffany Shellam's words, at 'shaking hands on the fringe' (Shellam, 2009). 


\section{Bibliography}

ATtwood, Bain (1989): The Making of the Aborigines, Sydney, Allen \& Unwin.

BRocK, Peggy (1993): Outback Ghettos: A History of Aboriginal Institutionalisation and Survival, Cambridge, Cambridge University Press.

Cipollone, Giulio / Orland, Clara (2011): Aborigeno con gli aborigeni per l'evangelizzazione in Australia. Il testo della Relazione (1883) per Propaganga Fide del vescovo Rudesindo Salvado, Vaticano, Libreria Editrice Vaticana.

CoOpes, Rhonda (2010): Australian Aboriginal Marginalisation in Policy Making and Education, Köln, Lambert.

Elder, Catriona (2009): Dreams and Nightmares of a White Australia, Berna, Peter Lang.

HaEbiCH, Anna (1992): For Their Own Good, Nedlands, University of Western Australia Press.

HAEBICH, Anna (2000): Broken Circles: Fragmenting Indigenous Families 1800-2000, Fremantle, Fremantle Arts Centre Press.

Haebich, Anna (2005): 'Clearing the Wheat Belt', in A. Dirk Moses, Genocide and Settler Society, New York, Berghahn Books.

HaEbich, Anna (2008): Spinning the Dream: Assimilation in Australia, Fremantle, Fremantle Press.

Hills, Stephen (2008): 'The Grand Experiment of the Civilisation of the Aborigines: A Missionary Endeavour in Western Australia', in Amanda Barry et al., Evangelists of Empire?: Missionaries in Colonial History, Melbourne, Melbourne University Press.

Linage Conde, Antonio (1999): Rosendo Salvado, Santiago de Compostela, Xunta de Galicia.

Maddison, Sarah (2011): Beyond White Guilt: The Real Challenge for Black-White Relations in Australia, Sydney, Allen \& Unwin.

McDonald, Lynn (2010): Florence Nightingale at First Hand, London, Continuum.

McGregor, Russell (1997): Imagined Destinies: Aboriginal Australians and the Doomed Race Theory, Melbourne, Melbourne University Press.

NeILl, Rosemary (2002): White Out: How Politics is Killing Black Australia, Sydney, Allen \& Unwin.

PradA, Albino (2014): Crónica desde el país de los sin alma: Rosendo Salvado en Australia, 1846-1899, A Coruña, La Voz de Galicia, Biblioteca Gallega.

RidE, Anouk (2007): The Grand Experiment, Sydney, Hachette Australia.

Rowse, Tim (2002): Indigenous Futures, Sydney, New South Wales University Press.

Rowse, Tim (2012): Rethinking Social Justice: From Peoples to Populations, Canberra, Aboriginal Studies Press.

Rowse, Tim / Shellam, Tiffany (2013): 'The Colonial Emergence of a Statistical Imaginary', Comparative Studies in Society and History, 55:4, October.

Russo, George (1980): Lord Abbot of the Wilderness. The Life and Times of Bishop Salvado, Melbourne, The Polding Press.

SAlVADO, Rosendo (1852 [1946]): Memorias históricas sobre la Australia y la misión benedictina de Nueva Nursia, Madrid, Editorial Católica.

SAlVADO, Rosendo (1864): Information respecting the aboriginal natives of Western Australia, Western Australia, State Records Office.

SHELLAM, Tiffany (2009): Shaking Hands on the Fringe, Nedlands, University of Western Australia Press. 
SHELLAM, Tiffany (2012a): "A mystery to the medical world": Florence Nightingale, Rosendo Salvado and the risk of civilization', History Australia, 9:1, 110-135.

SHELlam, Tiffany (2012b): "Our Natives" and "Wild Blacks": Enumeration as a statistical dimension of sovereignty in colonial Western Australia', Journal of Colonialism and Colonial History, 13:3.

SHellam, Tiffany (2014): '"On my ground": Indigenous farmers at New Norcia 1860s-1900s', paper presented at the symposium Da civilización á cultura: Rosendo Salvado e o mundo aborixe, Santiago de Compostela, Consello da Cultura Galega, 3-4 April 2014. 


\title{
LITERARY AND CULTURAL VOYAGES BETWEEN GALICIA AND AUSTRALIA ${ }^{1}$
}

\author{
María Jesús Lorenzo Modia \\ Universidade da Coruña
}

Doi: 10.17075/rsmaa.2016.en.012

1 This research was completed thanks to the aid included in the Programa de Consolidación (Consolidation Programme) granted by the Government of Galicia through the Rede de Lingua e Literatura Galega e Identidade (Galician Language and Literature and Identity Network) II R2014/043, which the author hereby expressly acknowledges. 


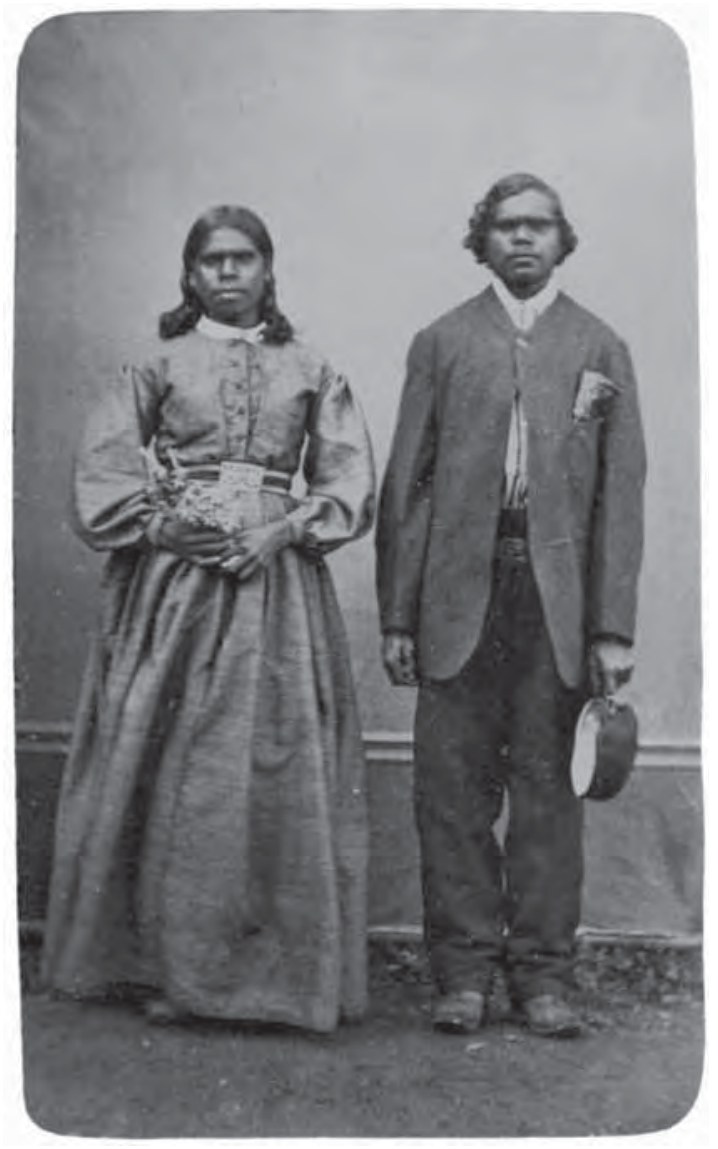


As is known, the relationships between Spain, and therefore Galicia, with the Antipodes began, as far as we are aware, with the arrival of the first navigators at those lands. In the year of 1519, we could find Galician sailors on Fernando de Magallanes' and Juan Sebastián Elcano's ships, in the age of discoveries. Around 1526 or 1527, the caravel San Lesmes departed from the port of A Coruña. There is information available that indicates that vessels from Galicia arrived in that continent as early as in the $16^{\text {th }}$ century, and that there was trade from A Coruña with the Molucca Islands and the adjoining territories; in fact, the establishment of a house of trade specialising in spices, named House of the Maluccas, had been authorised (Migués, 2008: 85). But it was only in 1606 that the lands that we know as Australia today saw the arrival of the expeditions of navigators Pedro Fernandes de Queirós (1565-1614) and Luis Váez de Torres (1565-1613?), which were critical in the discovery of those lands (Fernández de Quirós, 2000, III: 23; Pittarello, 1990; Hervé, 1983). It should be pointed out here that Quirós has been said to be Portuguese. It is not clear whether he was Portuguese by birth or simply had a Portuguese surname, but he was obviously at the service of Philip II, King of Castile, Aragon, Milan, etc., as well as Portugal between 1580 and 1598, just as he was later at the service of Phillip's son and successor, Philip III. There were also female travellers in the $17^{\text {th }}$ and $18^{\text {th }}$ centuries (Prieto, 1984), among whom we should highlight Isabel Barreto de Castro (1567?-1612), the Pontevedra-born wife of navigator Álvaro de Mendaña de Neira, the discoverer of the Solomon and also the Marquesas Islands (Bosch, 1943; Elías de Zevallos, 1995). She was the first woman to command a ship, after her husband's death, and arrived in Manila with Queirós. Incidentally, we may mention here that a novel by Francisco Núñez Roldán has just been released, Jaque al peón ('Check to the Pawn', 2014), winner of the Ciudad de Badajoz Novel Award, which presents an account of the union of Spain and Portugal based on the correspondence between Philip II from El 
Escorial and Lisbon's Rua do Comércio, where Cristóvão de Moura, the architect of such union, had settled (Alonso Giráldez, 2014, n. p.). Núñez's text reveals, among many other things, that identities were of a transnational nature at that time (Gil, 1989).

As can be seen in this very short journey through history, it was almost 500 years ago that we started our relationships with the Terra Incognita of the Antipodes (Fernández-Shaw, 2000: 83-89). Clearly, the discovery of Australia by Galician navigators is widely unheard of. It happened 200 years before the arrival of the British with Captain Cook, which took place in 1770. As Australian historian Kenneth McIntyre indicates in the title of his book The Secret Discovery of Australia, any discovery prior to the arrival of the British was forgotten. We need to bear in mind that the first settlement of the English on Botany Bay, in Sydney, did not start until January 1788 (Frost, 1980: 27).

One of the most illustrious Galician travellers to this island that is a continent at the same time, but which did not enjoy political unity until the $20^{\text {th }}$ century, is Rosendo Salvado, of whose birth we are commemorating the second centenary, and who arrived at Perth in 1846. Salvado's figure is present in Australia still today, as his legacy as founder of a community is a fact but, additionally, his work of recognition of Aborigines' cultural and artistic values is well known and is being highlighted and explored in this symposium. In the period during which Salvado arrived in Australia, colonists treated Aborigines in such a way that it amounted to a sort of slavery. In this context, Salvado's vision was to base the life of his community on principles of coexistence, thus creating a worldly Garden of Eden of sorts in which Aborigines themselves could educate their fellow human beings (Stormon, 1998). We might say that these $19^{\text {th }}$-century worlds are similar to those portrayed by Mario Vargas Llosa through the presence of painter Paul Gauguin in Tahiti in his novel El paraiso en la otra esquina (The Way to Paradise, 2003), since Salvado's ideal was paradise on Earth, or at least the improvement of the conditions in which Aborigines lived.

Although the relationships between travellers from Galicia and the Australian continent experienced many peaks and lows in the past, they are still alive, and Galicia is present in Australia through the teaching of the Galician language and literature in different communities, as well as universities such as Queensland, La Trobe, Sydney or Melbourne, where there are even centres for Galician 
studies. Having said this, what I intend to develop here is the idea that the figure of the Galician in Australia has remained alive in the collective imaginary, not only through the memory of navigators, in place names such as the Torres Strait, between Australia and Papua New Guinea, and through Salvado's work - still alive in the flourishing community of Benedictine friars in New Norcia - but also because of the importance of Galician elements in Australian literature. A great deal of Australia's contemporary literary production focuses on the exploration of a new reality by characters coming from beyond the seas, particularly European characters. This happens in the work of Peter Carey and other authors, and it also occurs that Galicia and Galicians have remained in the collective imaginary and have been turned into literary and creative material in the arts and literature, as is the case of Australian authors Murray Bail and Sally Morgan, and even British author Robert Graves. Alternatively, authors of Galician origin have also used the Australian theme in their texts, whether they publish their works here in Galicia or do it in English and are read in Australia and the United States.

One of the cases that I would like to bring to your attention today is that of Portuguese navigator Pedro Fernandes de Queirós, who gave the Terra Australis Incognita the name of 'La Austrialia del Espíritu Santo', or 'The South Land of the Holy Spirit', to honour the House of Austria reigning in Spain (Clark, 1962, I: 15). In the failed travels of Fernandes de Queirós - or Fernández de Quirós, as his name was adapted to the Spanish language, or Quiros in English - he imagined and proclaimed that he had arrived at what he called 'The Great South Land', and he was made an eternal figure in the imaginary of the inhabitants of the lands of which he dreamt, i.e., contemporary Australian artists. He was probably first recognised by the poet James McAuley (1917-1976) in the epic poem of 1964 entitled Captain Quiros. This text pays tribute to this navigator and his dreams as a hero, or rather a frustrated Australian antihero, as he was unable to realise his dream of carrying out his third voyage and setting foot on the island-continent. A few years later, in 1980, the best and best-known Australian music composer, Peter Sculthorpe (1929-), released The Visions of Captain Quiros: for guitar and orchestra. This composer has acknowledged his fascination with the epic linked to the figure of Queirós, whom he got to know through the work of the poet James McCauley. The figure of Pedro Fernandes 
de Queirós keeps becoming larger and larger in the collective imaginary of the people of Australia, and so in 1982 , to celebrate the $50^{\text {th }}$ anniversary of the Australian Broadcasting Corporation there, a commission was made to produce a TV opera entitled Quiros, in charge of the librettist Brian Bell and Peter Sculthorpe himself. In this TV production, our navigator is represented as a visionary idealist who pursues his dream, and does so even stubbornly, in view of his many failures and the many obstacles he comes upon. In the words of historian K. G. McIntyre, he was Australia's first patriot and first prophet (1977: 25). This idealistic vision of the continent that is to be discovered is present in several passages of the libretto, in the voice of Queirós:

I believe in the force that drives us past horizons of the mind... I believe that I could find in these dark seas the Great South Land.

East of India
West of the Solomons,
South of Java,

A continent.

$A$ vast land from tropic to the pole,

$A$ past and future to unfold,

A last grand enigma to be solved,

This continent.

And when the character of Queirós catches a glimpse of the failure of his frustrated voyages, he analyses the potential perverse effects that colonisation would entail, contrasting it with his idealistic vision of the travels to Australia undertaken by Europeans:

If we had reached the Great South Land,

With all our superstitions,

Our arrogance, our ignorance,

Our covetous ambitions, 
We should have spread our decadence,

Our fever and destruction,

And stamped upon that bright new world,

The old world's dark corruption.

In this way, the opera does not only contain a reflection on Queirós' voyages and his achievements or failures, but it also puts in his lips certain considerations that result from adopting a post-colonial standpoint, so that this contemporary perspective of re-visiting the history of Australia presents more inclusive, integrative images. The musician Peter Sculthorpe is known for including the works of Australian painters as inspiration in his compositions, particularly the paintings of Russell Drysdale (1812-1981), and these visions of Australian visual artists are probably incardinated in the musical composition commemorating Queirós, and surely in the plastic and aesthetic conception of this opera for TV.

Sculthorpe's work on Queirós was presented on 27 October of the year 2007 in the Sydney Opera House Concert Hall under the auspices of the Embassy of Spain in Australia, and is still scheduled there: it was included in the concert schedule of the capital city, Canberra, as late as in 2013. Additionally, the composer came back to the themes and music of Queirós and turned this into an oratorio entitled The Great South Land, which was broadcast on ABC Classic FM on Saturday 11 May 2013. The conversion of the opera into an oratorio allows it to be performed in concert halls, without requiring a large theatre. This change suggests that the piece has been transformed so that it may reach varied audiences in different places of the country. According to Stephen Adams (2013), the evolution of Queirós' character through Australian literature, music and opera from the 60s until today has been reflecting the country's and the intelligentsia's different stances on the conception of their identity as a people and on their own evolution, drifting away from Eurocentrism and recognising their reality from positions that imply the acceptance of their own historical complexities and contradictions (n. p.).

The Galician Isabel Barreto, contemporary with Queirós, has appeared as a novel character in both Spanish and Anglo-Saxon cultures. Isabel Barreto entered Hispanic letters thanks to Galician journalist Pemón Bouzas and his El informe Manila: Isabel Barreto, la que surcó los Mares del Sur en busca de las rutas 
de las especias ('The Manila Report: Isabel Barreto, Who Sailed the Southern Seas in Search of the Spice Route', 2005). Some fifty years earlier already, British literary critic, poet and novelist Robert Graves (1895-1985), the author of such memorable novels as I, Claudius (1934), had also made Isabel Barreto's voyages a theme for a novel in The Islands of Unwisdom (1949), published in Spanish as Las islas de la imprudencia (1984). As the main pilot of the fleet, Pedro Fernandes de Queirós is, together with Álvaro de Mendaña, one of the characters best portrayed in Robert Graves' novel. This story explores the reasons for the future Spanish failures in the conquest of the Pacific Ocean and for the Spanish Crown's loss of power in the world.

Part of the history of Australian literature revolves around the arrival of people in the country and their particular exploratory experience there. Explorations are not necessarily geographic but also psychological; and thus, we find coming-of-age novels, known as Bildungsroman, in which the characters recall the episodes they lived upon their arrival in the country. One of the novelists that dealt with this issue in depth is Peter Carey, who tackles the arrival in Australia of people from the different countries of the United Kingdom. In True Story of the Kelly Gang (2000) he recalls the harsh experiences of an Irish family who attempts to lift itself out of poverty by settling in the Antipodes in the $19^{\text {th }}$ century. He also sets in this period the voyage of English young men and women who intended to pursue a life project after arriving at Sydney. This happens in Oscar and Lucinda (1988), which constitutes a novel that owes much to magic realism and brings a not very distant past back to life. The dangerous expeditions through the Australian bush and jungles, the old descriptions of horses and carts crossing rivers and farmers and preachers colonising virgin, unknown territories, come to life both in Carey's novel and in Gillian Armstrong's film version (1997). Thanks to the book and the film based upon it, we are able to visit the $19^{\text {th }}$ century anew, from a post-modern, post-colonial perspective embodied in both cases in a narrator-character, Bob, and recover an approximate image of the Australian towns, lands, missions and ports of that time (Lorenzo Modia and Alonso Giráldez, 2008: 322). As García Márquez’s or Salman Rushdie's novels, Oscar and Lucinda seems to be based, too, on the many possibilities of chance and the many limitations of destiny. Carey uses a type of historical narration from a present-day perspective, thus bringing in an 
evaluative viewpoint (Woodcock, 2003: 73) and allowing us to learn from the mistakes of the past, whether personal or collective (Lorenzo Modia and Alonso Giráldez, 2008: 327). Carey challenges the relativity of human beliefs: he swings between irony and a certain pity for his characters. Oscar appears to accumulate more and more guilt as the film and the book move forward. Eventually, he will have to pay for his mistakes and sins. In a way, he is paying for both his father's mistakes and his own, as if he were repairing the original sin, just as happens with Europeans during the emigration to / colonisation of Australia (Lorenzo Modia and Alonso Giráldez, 2008: 328). Oscar's wish to find a logical explanation for life ends up in utter failure.

Carey clearly creates the character of Lucinda Leplastrier as a metaphor of fleeting light in Oscar's life of shadows. Still, her character has such a complex personality that it makes their relationship intense, complicated, potentially gratifying, although pointless and volatile. She is a young Australian heiress who wants to devote all her energy to glasswork, as she has taken a fancy to Prince Rupert's glass drops. $19^{\text {th }}$-century Sydney's society cannot understand this Australian businesswoman enthralled by glass. She focuses all her energy on an aesthetic dream, now influenced by Oscar's religious motivation: to found a glass cathedral in the Aboriginal territories. This enterprise, which might be aesthetically convincing, makes no sense either in the place or for the people, and eventually goes nowhere. Imperialism is thus criticised indirectly through religion, and it is said that it will undoubtedly end up in total failure. Violence is used in this case as the only way of stimulating new beliefs and erasing the old, former, prevailing ones, which are shared by the indigenous population and are still 'alive' through the spirits that wander the earth. Although she realises that she is in love, Lucinda is permanently isolated and there is always a considerable distance between her and Oscar (359). The love between them is less deep than the odyssey in which their dreams are immersed. This is, in a way, an epic novel, but reality is cruel even to epic dreams if these go against people and the land (Lorenzo Modia and Alonso Giráldez, 2008: 327). The sense of the land pervades the novel and they want to prevent this. In the end, Lucinda adopts a child of Oscar and Miriam, who acts as the emblem of their love and dreams, impossible as they can become true only after death. The continuation of this couple's story is a symbol of Australia's present history. They adopt a new land 
for their dreams, and even Lucinda adopts the daughter her dreams never allowed her to have.

The film-like characteristics of Carey's novel have attracted the attention of many critics since it was released. And so the novel was promptly brought to the screen, in 1997, by director Gillian Armstrong (Craven, 1998: 25-26; Carter, 2006: n. p.). Equally, many scholars saw a clear similarity between Carey's work and Werner Herzog's conquest films Aguirre, Wrath of God (1972) and Fitzcarraldo (1982) (Woodcock, 1996: 84). In fact, Oscar and Lucinda is considered to be the Australian Fitzcarraldo. Talking about her film version of the novel, Armstrong herself admitted, 'It was my little Fitzcarraldo' (Carter, 2006). Herzog's story deals with the bizarre figure of Brian Sweeney Fitzgerald, who was resolved to obtain money to build an opera house in what he called the frontier town, in the Peruvian jungle. The project is as grand as his apparent madness. Fitzcarraldo, as they called him, tries to avoid the rapids of the Peruvian river by transporting the steamboat overland, from a river to another. The film, magnificently shot (it is considered to be a masterpiece), describes splendidly the complexity of the herculean task they are resolved to carry out. The action is set in an exotic location (in fact, the filming was a nightmare). The landscape helps create a surreal atmosphere very close to the parameters of the so-called magic realism. We witness the struggle between the forces of man and the forces of nature, and the result is a violent, magic, astonishing film. As to Oscar and Lucinda, Gillian Armstrong manages to capture the spirit of the story in a classic way in her film, respecting the symbols that Peter Carey so much likes to use, and dealing with the heart of the story with the appropriate dose of emotion. Compared with the magnificent Fitzcarraldo, Oscar and Lucinda, too, attempts to integrate the essential dimensions of human nature, reaching a very rare balance between reason and madness. Oscar tries to take his glass cathedral to the interior of the Australian continent. In this regard, Oscar and Lucinda appears to be based upon the adventure of Rosendo Salvado trying to carry his piano and the materials to build a monastery through the Australian bush in the $19^{\text {th }}$ century so that Aboriginal men and women could have better spiritual and material lives.

It seemed relevant to mention here two novels by contemporary Australian authors in which Galician place names are of great importance. These novels are 
Murray Bail's Eucalyptus (1998) and Sally Morgan's My Place (1987). In the former, the name 'Corunna', which is the English term for the city of A Coruña, evokes a faraway place with legends and mysteries. The novel recounts the story of an Australian woman who falls in love with a dark stranger, and the two of them find themselves in front of a miraculous mirror in A Coruña's lighthouse:

There's a place called Corunna in north-west Spain, he had said. A place of rocks geological delirium. Corunna is known for just two things: foul weather, it never stops raining, and its lighthouse built of granite in the Dark Ages. Local families call it 'the Tower of Caramel'. (208)

The narration about A Coruña appears as a mirror image, as a story is created in the Antipodes reflecting the one that unfolds in that Galician city, at which the woman in love arrives in search of her lover, whom she can no longer find (Cabarcos, 2008: 265). A mirror relationship is established, therefore, between what happens to the novel's protagonist in Australia and what happens to the imaginary character she thinks of and who comes to A Coruña. These parallelisms are illuminated by the mirrors that were historically used in the Tower of Hercules to enhance the projection of the light from the lighthouse, which looks like caramel because of the colour of the granite of the façade. Waiting for her lover, Ellen is trapped in a metaphorical tower too. There is always a non-reversed image and a reversed one in a reflection, and on this occasion it is the woman from A Coruña who cannot find her lover so that Ellen may be happy with hers in the reversed image.

In the case of Sally Morgan's My Place, the place name 'Corunna' appears as such in 'Return to Corunna' and as a personal name or family name in three sections with an independent title, called 'Arthur Corunna's Story', 'Gladys Corunna's Story' and 'Daisy Corunna's Story'. These names come from the Australian place name Corunna Downs, located in Western Australia, as one of the protagonist's ancestors is from a ranch there:

Corunna Downs was named by my husband. There is a poem, "Corunna". He was reading a book at the time with the natives, and in it was a poem about Corunna, I think it was in Spain, so he named the station after that. (Morgan, 2003: 168) 
The best-known poem about A Coruña in the Anglo-Saxon canon is the one created by Irish writer Charles Wolfe on the Battle of Elviña, known in the United Kingdom as the Battle of A Coruña, which took place in January 1809 in the context of the fight between the French and the English in Spain for preeminence in Europe and in the world. It was called the Peninsular War in England and is known as the War of Independence in our country. The English saw their own forces as inferior, and decided to avoid the clash with the Napoleonic troops and withdraw by sea through the port of A Coruña. The strategy was successful but the British general in command, sir George Moore, did die in the fight on Elviña's hills, located at the entrance of the town of A Coruña, which has become the Elviña university campus today. Wolfe fist published the poem 'On the Burial of Sir John Moore after Corunna' in the journal The Newry Telegraph in 1817 and later, anonymously, in Scotland's Blackwood's Magazine. The poem attracted the attention of such illustrious readers as Lord Byron, Edgar Allan Poe or George Orwell, as well as different anthologists, who kept disseminating the poem until it came to be the most widespread patriotic elegy in the British Empire (Cabarcos, 2008: 269), one that is a compulsory part of all Anglo-Saxon schoolchildren's education. Even Galician writer Rosalía de Castro wanted to do her share in the literary mourning and published a poem entitled 'Na tomba do xeneral Sir John Moore' ('At the Grave of General Sir John Moore').

In this context, the battle of powers that unfolded in Europe through this Galician town in the early $19^{\text {th }}$ century is represented in Australian fiction with a different meaning. The colonial power takes possession of new territories, which includes Aborigines, who must now serve the British and even become their property. Aborigines receive the names and surnames chosen for them by their masters, who in this way avoid recognising Aborigines' own identity, origin and culture. As Nan states in relation to the Aborigines working in ranches in the $19^{\text {th }}$ century, i.e., in Salvado's time, 'in those days, we was owned, like a cow or a horse' (Morgan, 2003: 337, quoted in Cabarcos, 2008: 274). That is, Aborigines were not considered to be human individuals but working animals. The name 'Corunna', which in the metropolis was associated with deliverance from the Napoleonic yoke in Spain, the first step towards Napoleon's final defeat, takes up different meanings in Sally Morgan's novel depending on 
whether it is landowners or Aborigines who pronounce it. For women, this submission is twofold, as they are also sexually exploited by the master of the ranch. After a sexual relationship with Annie, Nan is born and later becomes a worker in the property, with whom the master has an incestuous relationship that produces new workers for the plantation (Cabarcos, 2008: 274). As time goes by, the old farm called Corunna becomes an airbase for Australian forces in World War II and, again, takes up the meaning of a place of deliverance from the yoke of Axis troops. Later on, it even receives recognition for advancing agricultural work in northwest Australia.

As we can see, Galicia's relationship with Australia lives on in place names, whether they were carried there by Galicians or by travellers that symbolically maintained such names in their iconography. The meaning of these place names becomes increasingly complex across Australia and is more evident depending on the period in which they are studied and the point of view from which this is done.

There are other elements of Galician culture that have endured in Australian culture and literature to this day: the Galicians who, during the great maritime migrations of the fifties and the sixties, emigrated to Australia from Spain or other countries in which they had settled earlier, such as Brazil, France or England, among others. Galicians and Spaniards arrived on steamboats chartered by the Australian government within a number of programmes known as 'Canguro', 'Eucaliptus', 'Emu' or 'Kerry'. Also, contingents of approximately 500 unmarried women arrived in Australia within a programme called 'Marta'. These women had been recruited, in cooperation with the Spanish Church, to keep company in Australia to the more than 7,000 men who emigrated at that time (Boland, 2008: 16). Many of these people, and especially their children, found in Australia the better future they aimed at - although others did not have it so good.

Some of these emigrants are publishing in English a number of texts in which they use Galicia as theme. One of these authors is Félix Calviño, or Calvino, as he is known in the Antipodes. Born in 1944, this author depicts the memories of his childhood in Galicia and presents in his literature the difficulties of emigration from a Galician's point of view, turning so many people's lives into literature that readers from different continents may find familiar. One of 
Calviño's texts is a collection of short stories: A Hatful of Cherries, which was published in 2007 and again in 2011. It was a great success right from the start, which was discussed in the conference on Australia that we held in A Coruña around those days. These sixteen short stories have been created by an author that, iconically, comes from elsewhere. It seems ironic that the name of the village where he was born is precisely Alemparte ('Elsewhere'), in Lalín, and that he nevertheless has a good command of the English language and chose to devote himself to literature in his later years, giving up his flourishing career as a businessman in Australia. Roy Boland, from the University of Sydney, mentioned that Calviño has published texts in the most prestigious journals in the Antipodes, such as Quadrant, among whose collaborators are authors of stature such as Peter Carey or David Malouf (Alonso, 2008: n. p.). Calviño's use of the English language is extraordinary, but that mixture of Galician features - particularly the themes of 'Don't Touch Anything', 'Detour' or 'Basilio' - and the foreign features of the Australian language and culture results in texts of a strange beauty that makes his English highly attractive. According to Professor Boland, Félix Calviño has chosen to use Galician themes and write like AngloSaxon authors, and his originality results from that mixture. As he himself states in the foreword to his book of short stories, he left Galicia so as to avoid the military service that was compulsory during Francoism. The author declared in an interview that writing allowed him to learn a lot and explore the connexions between memory and imagination in depth. He deals with themes such as childhood or the hard post-war years in Galicia, but also apparently unimportant events that take place in the streets of Australian towns and which are suggestive of suspense, chance or a grave tragedy. The different places in which the stories develop do not make a disjointed book, but one that is an archetype of Australian essence, historically made up by emigrants. The stories are full of tenderness, humour and irony in the treatment of everyday issues, in a simple, clear style, as in the following sentence: 'Grandfather had become disillusioned with women when my Grandmother died young and without his consent' (Calvino, 2007: 42).

When we say 'success', it is not because we are driven by legitimate pride as Galicians to extol the work of a fellow countryman; rather, such success is confirmed by the voice of one of the great authors of Australian literature, David 
Malouf (1934-), a playwright and poet who is, however, known especially for his novels Fly Away Peter (1982) and Remembering Babylon (1993). Talking about Félix Calviño's collection of short stories, Malouf said,

Lively, moving, humorous, strange, these small records of other lives in another place are a gift, and so is the austere and tender mode of their telling. Calvino's is a new voice in the room, individual, arresting, and now that we have been aware of it, indispensable to the many others that make up our story.

Maloufs statement about a book of short stories with a Galician theme as contributory to the construction of Australia's history, and what immigrants provided to it, relates to the essence of the country itself, built from the periphery by immigrants of all sorts. Australia is still an unexplored country, in which most people are located in the periphery, facing the ocean and partially turning their backs on that unknown land. This is why many of those who shaped Australia are immigrants who still feel that they are exploring the territory. In this context, contemporary writers perceive that Australia is not yet a country; for they do not speak from the inside but from the periphery, following poet and conservationist Judith Wright (1915-2000). This idea was worded as follows: 'Australia is still, for us, not a country but a state of mind. We do not yet speak from within her, but from the outside' (1969: 301). Therefore, if we understand that reality, in the Australian collective imaginary, is that of a community imagined by people of many different origins (Anderson, 1983: 6-7), we will see the point of Maloufs statement that the texts of an author of Galician origin which deal with Galician circumstances help build Australia's history. In this regard, the periphery and the margins turn into a place of creation and power and become central in the contemporary history of Australian literature (Hooks, 1990: 152).

Australian writer Venero Armanno (1959-) said in the presentation of this book of short stories that there is no romanticism in Calviño's style; rather, his style is very natural. Armanno also asserted that he does not believe that Calviño is very far from Giuseppe Tomasi di Lampedusa, from Italo Svevo, from Italo Calvino (no relation!) or from his favourite, Cesare Pavese, he added. 
One of Félix Calviño's short stories was adapted for the screen in a short film entitled Unfinished Thoughts. It received much recognition in Australia: it was nominated for eight South Australia Screen Awards and won the award for best actress, given to Chantal Contouri. Even though its director, Dimitrios Pouliotis, is of Greek origin, and the film is set in a Greek cultural context, we can see the Galicia of emigration without doubt when we watch it.

Recently, in January 2014, Félix Calviño released a novella entitled Alfonso. Again, the writer David Malouf participated in the presentation, held in Sydney on 20 February 2014. The writer of Italian origin Venero Armanno stated about this new novella,

Alfonso is a gentle yet searching exploration of a Spanish migrant's feelings and experiences in the country Australia used to be more than forty years ago. Felix Calvino infuses the stuff of everyday life with tenderness and magic. He recovers a lost time and sensibility. The past shimmers back to life.

It was also said in the presentation of the book that everything is given up in this experience of emigration in exchange for material safety. The author talked about the five literary influences that have been fundamental for him: these are Cervantes, Flaubert, Chekhov, Hemingway and García Márquez (Horner, 2009: n. p.).

To conclude, I have attempted to show that travellers from our country are present in poems, operas, musical compositions and novels, as is the case of the navigator Queirós, and are mentioned in studies such as that entitled 'Imagining Australia' (Adams, 2013), thanks to which they are contributing to the construction of the contemporary Australian identity. This also happens in novels about people coming from the British Islands, as is the case of Peter Carey, who in the late $20^{\text {th }}$ century published novels dealing with the construction, exploitation and exploration of the country in the $19^{\text {th }}$ century by Britons who had arrived at Sydney. Sally Morgan and Murray Bail use the name of the city of A Coruña with different meanings: first, those that the term may evoke to the inhabitants of this Galician city; second, to the Britons who remembered the term when they gave this name to a specific area in Australia; and third, to the Australians who lived in that area, depending on the times and 
the lives they lived, and depending on whether they were masters or Aborigines. The matter of Galicia appears in the works of other contemporary Australian writers too, as is the case of Félix Calviño, so the rural culture of Galicia after the Civil War becomes part of the collective imaginary about the multiethnic origins of present-day Australia, and is in process of becoming part of the literary canon in Australia thanks to writers such as David Malouf, no less. Therefore, the formation of what we believe to be a country includes our images of it, taken from maps, newspapers and artistic manifestations, and therefore we think that Galicia is one of the constituent elements of contemporary Australian literature. 


\section{BIBLIOGRAPHY}

ADAMs, Stephen (2013): 'Imagining Australia', Australian Music, 7 May (http://www.abc.net.au/classic/ content/2013/05/07/3753891.htm).

AguirRe, Wrath of God (dir. Werner Herzog, perf. Klaus Kinski, Helena Rojo, Ruy Guerra, Peter Berling), Hessischer Rundfrunk, 1972.

Alonso Giráldez, José Miguel (2008): 'Félix Calviño publica en inglés un libro de relatos galaicos en Australia', El Correo Gallego, 18 May.

Alonso Giráldez, José Miguel (2014): 'El sábado libro: Felix Calviño, escritor gallego en lengua inglesa», El Correo gallego, 24 May (http://www.elcorreogallego.es/tendencias/ecg/felix-calvino-escritor-gallegolengua-inglesa/idEdicion-2014-05-24/idNoticia-870620/\#).

ANDERSON, Benedict (1983): Imagined Communities: Reflections on the Origin and Spread of Nationalism, London, Verso.

ANDERSON IMBERT, Enrique (1976 [1992]): El realismo mágico y otros ensayos, Caracas, Monte Ávila.

ArCher-Lean, Clare (2007): 'Review - Social Alternatives' [review of A Hatful of Cherries], Social Alternatives, 26:4 (http://ahatfulofcherries.blogspot.com.es/2008/11/review_11.html).

BaIL, Murray (1998 [1999]): Eucalyptus, London, Harvill Press.

Boland Osegueda, Roy C. (2008): 'The Search for Paradise. Reflections on Historical and Cultural Relations between Spain, Galicia and Australia', in María Jesús Lorenzo Modia / Roy C. Boland Osegueda (eds), Australia and Galicia: Defeating the Tyranny of Distance = Australia e Galicia: Vencendo a tiranía do afastamento, Antípodas Monographs, Sydney, 9-20.

Bosch Barrett, Manuel (1943): Doña Isabel Barreto: Adelantada de las islas Salomón, Barcelona, Juventud.

BOUZAS, Pemón (2005): El informe Manila, Madrid, Martínez Roca.

Cabarcos Traseira, María Jesús (2008): 'Heroes and Mirrors: The Presence of Corunna in Murray Bail's Eucalyptus and Sally Morgan's My Place', in María Jesús Lorenzo Modia / Roy C. Boland Osegueda (eds), Australia and Galicia: Defeating the Tyranny of Distance = Australia e Galicia: Vencendo a tirania do afastamento, Antípodas Monographs, Sydney, 257-274.

Calvino, Félix (2007): A Hatful of Cherries: Short Stories, Kew, VIC, Arcadia (an imprint of Australian Scholarly Publishing).

Calvino, Félix (2009): 'They Are Only Dreams', The Barcelona Review, and K. Scott Forman / Kona Morris / Nancy Stohlman (eds), Fast Forward, Vol. 2, FF > Press.

Calvino, Félix (2013): Alfonso, Sydney, Arcadia.

CAREY, Peter (1988): Oscar and Lucinda, Brisbane, The University of Queensland Press.

CareY, Peter (2000 [2002]): True Story of the Kelly Gang, London, Faber.

CARTER, Helen (2006): 'Gillian Armstrong', Senses of Cinema, 15 September (http://www.sensesofcinema. com/contents/directors/02/armstrong.html\#16).

Clark, Manning (1962-1987): A History of Australia, Melbourne, Melbourne University Press, 6 vols.

Craven, Peter (1998): 'Review of the film Oscar and Lucinda', Australian Book Review, 198: 25-26.

DAlley, Helen (2004): 'Sally Morgan: Claims of Fabrication', Cover Stories, ninemsm, 21 March 2004 (transcription available at http://sunday.ninemsn.com.au/sunday/cover_stories/article_1507.asp) [last accessed: 5 September 2007]. 
Edgar Allan Poe Society of Baltimore, Inc. (1999/2007): 'Poe's Criticisms', The Works of Edgar Allan Poe, USA, 20 August 1999 (http://www.eapoe.org/works/criticsm/wolfe.htm) [last accessed: 20 October 2007].

Elías de Zevallos, Hilda (1995): El entorno de Isabel Barreto Castro de Mendaña y su viaje hacia las Islas Salomón, Lima, Asociación Nacional Pro-Marina del Perú.

FERnÁndez de Quirós, Pedro (2000): Descubrimiento de las regiones austriales (ed. Roberto Ferrando Pérez), Madrid, Dastin Historia.

FERnÁndeZ-SHAW, Carlos M. (2000): España y Australia: Cinco siglos de historia = Spain and Australia: Five Hundred Years of Relations (ed. Mercedes Palau and Alonso Ibarrola), Madrid, Dirección General de Relaciones Culturales y Científicas, Ministerio de Asuntos Exteriores de España, 83-89.

Fitzcarraldo (dir. and prod. Werner Herzog, perf. Klaus Kinski, Claudia Cardinale, Paul Hittscher, Miguel Ángel Fuentes, José Lewgoy), West Germany, 1982.

Frost, Alan (1980): Convicts and Empire: A Naval Question (1776-1811), Melbourne, OUP.

GarCía MárqueZ, Gabriel (1967 [2007]): Cien años de soledad [commemorative edition], Madrid, Real Academia Española / Asociación de Academias de la Lengua Española / Alfaguara. [Trans. Gregory Rabassa (1970): One Hundred Years of Solitude, New York, Harper and Row.]

GIL, Juan (1989 [1992]): Mitos y utopias del Descubrimiento: El Pacifico, Madrid, Alianza Universidad, 3 vols.

Graves, Robert (1949): The Islands of Unwisdom, London, Carcanet (rpt. 2003, New York, Doubleday).

Graves, Robert (1984): Las islas de la imprudencia, Barcelona, Edhasa (trans. Rubén Masera).

Hervé, Roger (1983): Chance Discovery of Australia and New Zealand by Portuguese and Spanish Navigators between 1521 and 1528, Palmerston North, The Dunmore Press.

Hooks, Bell (1990): Yearning: Race, Gender and Cultural Politics, Boston, Massachusetts, South End Press. Horner, Anna (2009): 'Félix Calvino, author of A Hatful of Cherries, makes U.S. debut', Baltimore Literature Examiner, 30 July (http://www.examiner.com/article/f-lix-calvino-author-of-a-hatful-ofcherries-makes-u-s-debut).

Lorenzo Modia, María Jesús / Alonso Giráldez, José Miguel (2008): 'Misfits in the Hands of Destiny: Peter Carey's Antipodean Conquest in Oscar and Lucinda', in María Jesús Lorenzo Modia / Roy C. Boland Osegueda (eds), Australia and Galicia: Defeating the Tyranny of Distance = Australia e Galicia: Vencendo a tirania do afastamento, Antípodas Monographs, Sydney, 321-336.

Majó Framis, Ricardo (1946): Navegantes y conquistadores españoles del siglo XVI, Madrid, Aguilar.

MÁrquez de la Plata, Vicente María (2006): Mujeres de acción en el Siglo de Oro, Madrid, Castalia.

McAuley, James (1964): Captain Quiros, Sydney, Angus \& Robertson.

MCInTYRe, Kenneth Gordon (1977): The Secret Discovery of Australia: Portuguese Ventures 200 Years Before Captain Cook, London, Souvenir Press.

MCInTyre, Kenneth Gordon (1984): The Rebello Transcripts: Governor Phillip's Portuguese Prelude, London, Souvenir Press.

Migués Rodríguez, Vítor Manuel (2008): 'Early Links Between Galicia and the Pacific: The House of the Maluccas in Corunna', in María Jesús Lorenzo Modia / Roy C. Boland Osegueda (eds), Australia and Galicia: Defeating the Tyranny of Distance = Australia e Galicia: Vencendo a tirania do afastamento, Antípodas Monographs, Sydney, 85-100.

Morgan, Sally (1987 [2003]): My Place, London, Virago Press.

NúNEZZ RoldÁn, Francisco (2014): Jaque al peón, Sevilla, Algaida. 
Orwell, George (2008): 'The Lion and the Unicorn', Charles' George Orwell Links (http://www. netcharles.com/orwell/essays/lion-andunicorn1.htm) [last accessed: 5 September 2007].

OSCAR and Lucinda (dir. Gillian Armstrong, perf. Ralph Fiennes, Cate Blanchett, based upon the novel of the same name by Peter Carey) [CD-ROM], USA / Australia / United Kingdom, Twentieth Century Fox, 1997.

Pittarello, Elide (ed. and intr.) (1990): Pedro Fernández de Quirós: Viaje a las islas Salomón (1595-1596), Roma, Consiglio Nazionale delle Ricerche / Bulzoni Editore.

PoE, Edgar Allan (ca. 1825): unpublished notice of 'The Burial of Sir John Moore', rpt 'Notice of "The Burial of Sir John Moore"', 20 August 1999, USA, Edgar Allan Poe Society of Baltimore, Inc. (http:// www.eapoe.org/works/criticsm/wolfe.htm) [last accessed: 20 October 2007].

Portsmouth Napoleonic Society (1999): 'The Battle for Elvina', Portsmouth, September (http://www. pns1814.co.uk/corunna.htm) [last accessed: 20 October 2007].

Prieto, Carlos (1984): El Océano Pacífico: Navegantes españoles del siglo XVI, Madrid, Alianza Editorial.

SCUlthorpe, Peter (1980): The Visions of Captain Quiros: for guitar and orchestra, London, Faber.

Sculthorpe, Peter (2013): The Great South Land, ABC Classic FM, Saturday 11 May.

SCUlthorpe, Peter / Bell, Brian (1982): Quiros [ABC TV film].

STORMON, Edward J. (1998): The Salvado Memoirs, Nedlands, University of Western Australia.

VARGAS Llosa, Mario (2003): El paraiso en la otra esquina, Barcelona, Alfaguara.

Woodcock, Bruce (1996): Peter Carey, Manchester, Manchester UP (2 ${ }^{\text {nd }}$ ed. 2003).

Wolfe, Charles (1979): 'The Burial of Sir John Moore after Corunna', in Helen Gardner (ed.), The Oxford Book of English Verse: 1250-1950, Oxford, Oxford University Press, 579-580.

Wright, Judith (1969): 'The Upside-Down Hut', in John Barnes (ed.), The Writer in Australia, Melbourne, Oxford UP.

ZARAGOZA, Justo (1876-1882): Historia del descubrimiento de las regiones austriales hecho por el general Pedro Fernández de Quirós, Madrid, Impr. de Manuel G. Hernández, 3 vols. 
ROSENDO SALVADO

AND US ABORIGINES

\section{Paul Willaway}

Executive Director of the New Norcia Aboriginal Corporation

Doi: 10.17075/rsmaa.2016.en.013 


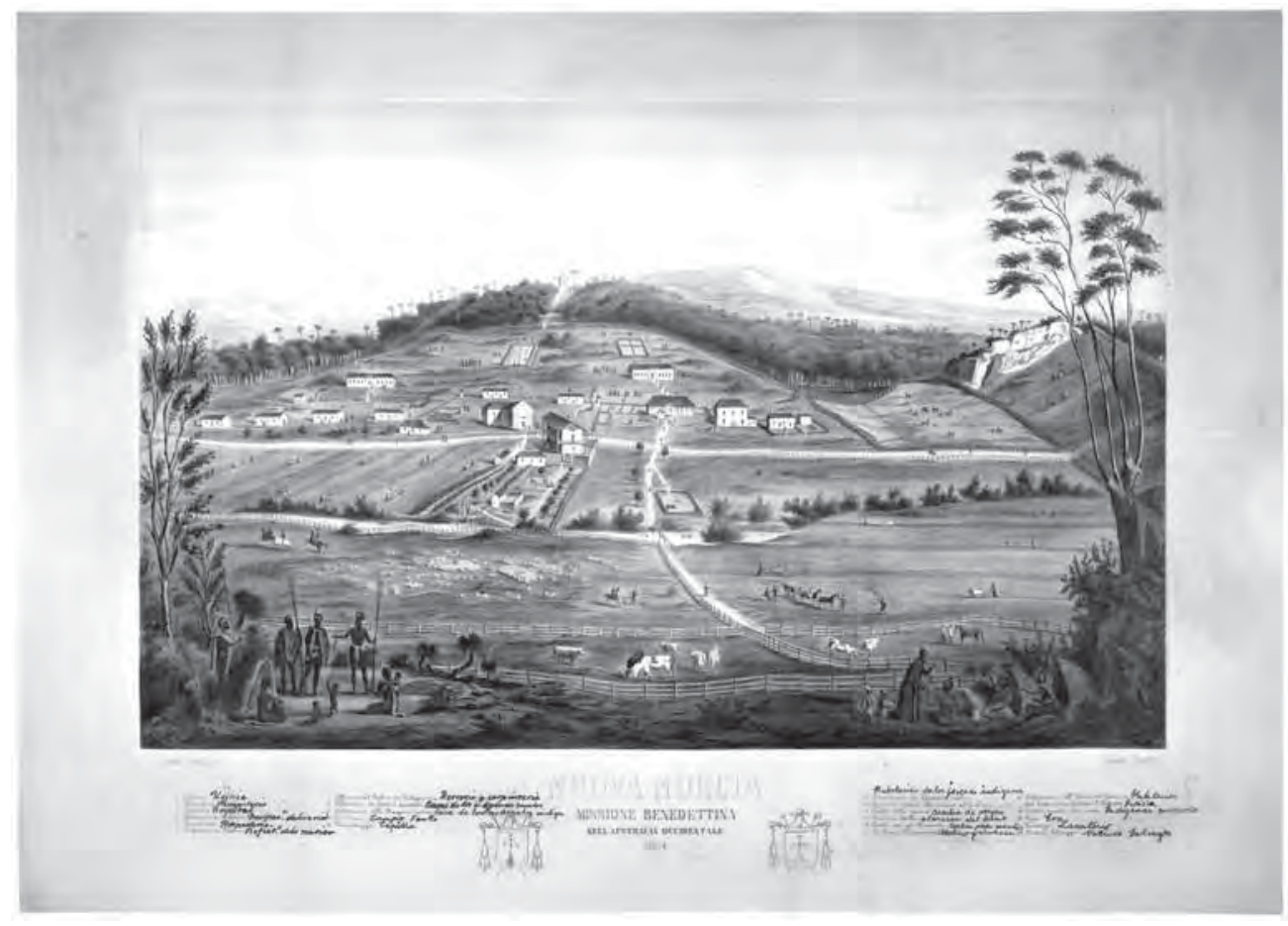


It is a very special honour to be here as a representative of the Aboriginal people of New Norcia at this very important symposium. My fellow Aboriginal representative, Karen Ryder, at the last moment was not able to team with me.

Before I say anything further, it is becoming commonplace in Australia at important events such as this symposium to acknowledge the Aboriginal group on whose original country we are meeting, and also to pay our respects to our elders, past and present. As such, I would like to acknowledge the Galician people and pay my respects to your elders and leaders, past and present, and in particular Bishop Rosendo Salvado. I would also like to express gratitude to the Council for the Galician Culture and its president, Ramón Villares, for the invitation and arranging the generous sponsorship to come to this symposium, and I would also like to thank the Australian Embassy in Spain and its ambassador, Jane Hardy, for its generous contribution that allowed me to travel here from Australia.

Firstly, I would like to share with you something about myself and my family's connexion to New Norcia. You may be wondering, as an Aboriginal representative, I am not very dark-skinned, like the people you have seen in photographs. This is because my mother is Aboriginal and my father Spanish - not Galician but Castilian. However, my father and mother were not together when I was born, and I was brought up with my mother's family at New Norcia. My surname, Willaway, is my mother's family name. My family are a part of the Aboriginal tribe of New Norcia and the surrounding region, the Yued Noongar people, and the Willaway family has a long association with New Norcia and the Benedictine monks, which began not long after Bishop Salvado established the Aboriginal mission there in 1847. I especially would like to mention my grandparents, whom I lived with, Harold and Philomena Willaway, who lived at New Norcia for most of their lives. They were both respected elders and played an active role in the community life at New Norcia. And, in recognition 
of their ties with the New Norcia Benedictine Community, my grandparents were made Benedictine oblates, and when they died they were buried with the Benedictine scapular in accordance with their oblate rights. My grandfather was even buried wearing a monk's habit that belonged to the then abbot of New Norcia.

One of my grandparent's children joined, at the age of thirteen years, the Benedictine Missionary Sisters of New Norcia. Her religious name is Sister Veronica. When the Aboriginal mission at New Norcia closed, the Spanish Benedictine sisters returned to Spain and Sister Veronica chose to return with them and lived in Barcelona for about five years. She is still a nun and is now based at a Benedictine community in the USA.

The Willaway family is very proud of their long association with the Benedictine Community at New Norcia. For us, it was a positive and beneficial experience. We learnt the necessary skills to participate in modern Australia. I personally feel a very deep sense of connexion to New Norcia, with both Aboriginal and Spanish heritage. As you may be aware, Bishop Salvado's primary purpose in establishing a mission at New Norcia was to Christianise and civilise the Aboriginal people of the area. It must be acknowledged that missions generally in Australia played a crucial role in assimilating Aboriginal people and cultural deprivation. It is a very complex history that needs to be considered in the context of the time and from whose perspective is told. There has been a lot written and said about Bishop Salvado and the Aboriginal mission at New Norcia that he established; however, the Aboriginal voice - or, more correctly, voices - about this is still emerging. Some of this has been positive, and some of this negative. In addition to the positive outcomes, there are Aboriginal people who have said they did not benefit from the experience of New Norcia. Some have highlighted the harsh treatment they received as children at residential institutions during their time at the mission.

Only a few Aboriginal people remain living at New Norcia, with most of the people with family connexions to New Norcia living elsewhere. To help maintain ongoing connexions to New Norcia, the New Norcia Aboriginal Corporation - as I will call it, 'the Corporation' - was established in the early 1990s. The Corporation formally represents the Aboriginal people of New Norcia and 
works in partnership with the Benedictine Community of New Norcia to ensure the Aboriginal heritage of the place remains visible.

In this bicentenary year of Salvado's birth, the Corporation has been collaborating with the Benedictine Community in events commemorating Bishop Salvado's life and legacy. As part of this, the Benedictine Community has produced the Salvado Bicentenary Souvenir Booklet - I have given Ramón a copy - which was launched on his birthday, the $1^{\text {st }}$ of March, in New Norcia, after a commemorating mass. The Benedictine Community invited the Corporation to contribute a message for the booklet, and I would like to share the message with you:

On behalf of the New Norcia Aboriginal Corporation we extend our congratulations to the Benedictine Community as they celebrate the bicentenary of the birth of their founder, Bishop Rosendo Salvado.

The establishment of the Aboriginal mission at New Norcia had a profound effect on the lives of the local Aboriginal people, the Yued people of the Noongar nation. This coincided with much upheaval for the Noongar people who bore the brunt of the early British colony in Western Australia.

We consider that Bishop Salvado was a friend of the Yued people. Bishop Salvado gained the trust of the Yued people who helped him and his fellow missionaries survive in the bush and to establish the mission at New Norcia.

Bishop Salvado had a deep interest and respect for Aboriginal people in which he recorded the local Noongar language, culture and customs. Those records have provided important historical information about Noongar people [and their families], including being used to support the Noongar native title claim.

In the spirit of reconciliation, we look forward to participating in events commemorating Bishop Salvado's life and his legacy.

In concluding, with Santiago de Compostela being a place of pilgrimage, coming here for this symposium and visiting Bishop Salvado's birthplace in Tui two days ago has been a very special journey for me. It has allowed me to fulfil a dream to pay homage to this great man, whose legacy has deeply impacted my life. 

The commemoration of the 200th anniversary of Rosendo Salvado's birth (Tui, 1 March 1814) is a timely occasion to delve into a key aspect of his life and work, one that is, in fact, the keystone of all of his extraordinary career: his indigenist thinking and practice. His commitment to the Aboriginal world involved the radical rejection of the brutal ethnocentric, racist approach that was customary in the time of the British Empire, i.e.. the approach whereby the Aborigines were considered miserable 'soulless' bodies, the remnants of a 'doomed race' (the doomed race theory), or even beings belonging to the same species 'as orangutans'. The emphasis laid on the extraordinary dimension of his missionary efforts, or a misguided focus on his legendary importation of eucalyptus to Galicia, have concealed the very core of his life project - his formidable efforts to promote the personal and political autonomy of Australian Aborigines as human beings with rights and, therefore, with a civil future. Salvado carried out this task displaying, at all times, an openly belligerent attitude against the discourses and practices that both Protestantism and Catholicism had established, and his ways were far removed from those of 'evangelists of empire'.

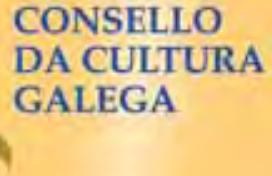

